\title{
Torah \\ The Quintessential Blueprint an approach to contemporary Jewish Architecture
}

by

Jeremy Aranoff

b.a.s.

A thesis submitted to the Faculty of Graduate and Postdoctoral Affairs

in partial fulfillment of the requirements for the degree of

Master of Architecture

M. ARCH PROFESSIONAL

School of Architecture

Carleton University

Ottawa, Ontario

September 25, 2012

COPYRIGHT @ 2012 Jeremy Aranoff. ALL RIGHTS RESERVED 
Library and Archives

Canada

Published Heritage

Branch

395 Wellington Street

Ottawa ON K1A ON4

Canada
Bibliothèque et

Archives Canada

Direction du

Patrimoine de l'édition

395 , rue Wellington

Ottawa ON K1A ON4

Canada
Your file Votre référence

ISBN: 978-0-494-93642-9

Our file Notre référence

ISBN: $978-0-494-93642-9$
NOTICE:

The author has granted a nonexclusive license allowing Library and Archives Canada to reproduce, publish, archive, preserve, conserve, communicate to the public by telecommunication or on the Internet, loan, distrbute and sell theses worldwide, for commercial or noncommercial purposes, in microform, paper, electronic and/or any other formats.

The author retains copyright ownership and moral rights in this thesis. Neither the thesis nor substantial extracts from it may be printed or otherwise reproduced without the author's permission.
AVIS:

L'auteur a accordé une licence non exclusive permettant à la Bibliothèque et Archives Canada de reproduire, publier, archiver, sauvegarder, conserver, transmettre au public par télécommunication ou par l'Internet, prêter, distribuer et vendre des thèses partout dans le monde, à des fins commerciales ou autres, sur support microforme, papier, électronique et/ou autres formats.

L'auteur conserve la propriété du droit d'auteur et des droits moraux qui protege cette thèse. $\mathrm{Ni}$ la thèse ni des extraits substantiels de celle-ci ne doivent être imprimés ou autrement reproduits sans son autorisation.
In compliance with the Canadian Privacy Act some supporting forms may have been removed from this thesis.

While these forms may be included in the document page count, their removal does not represent any loss of content from the thesis.
Conformément à la loi canadienne sur la protection de la vie privée, quelques formulaires secondaires ont été enlevés de cette thèse.

Bien que ces formulaires aient inclus dans la pagination, il n'y aura aucun contenu manquant. 


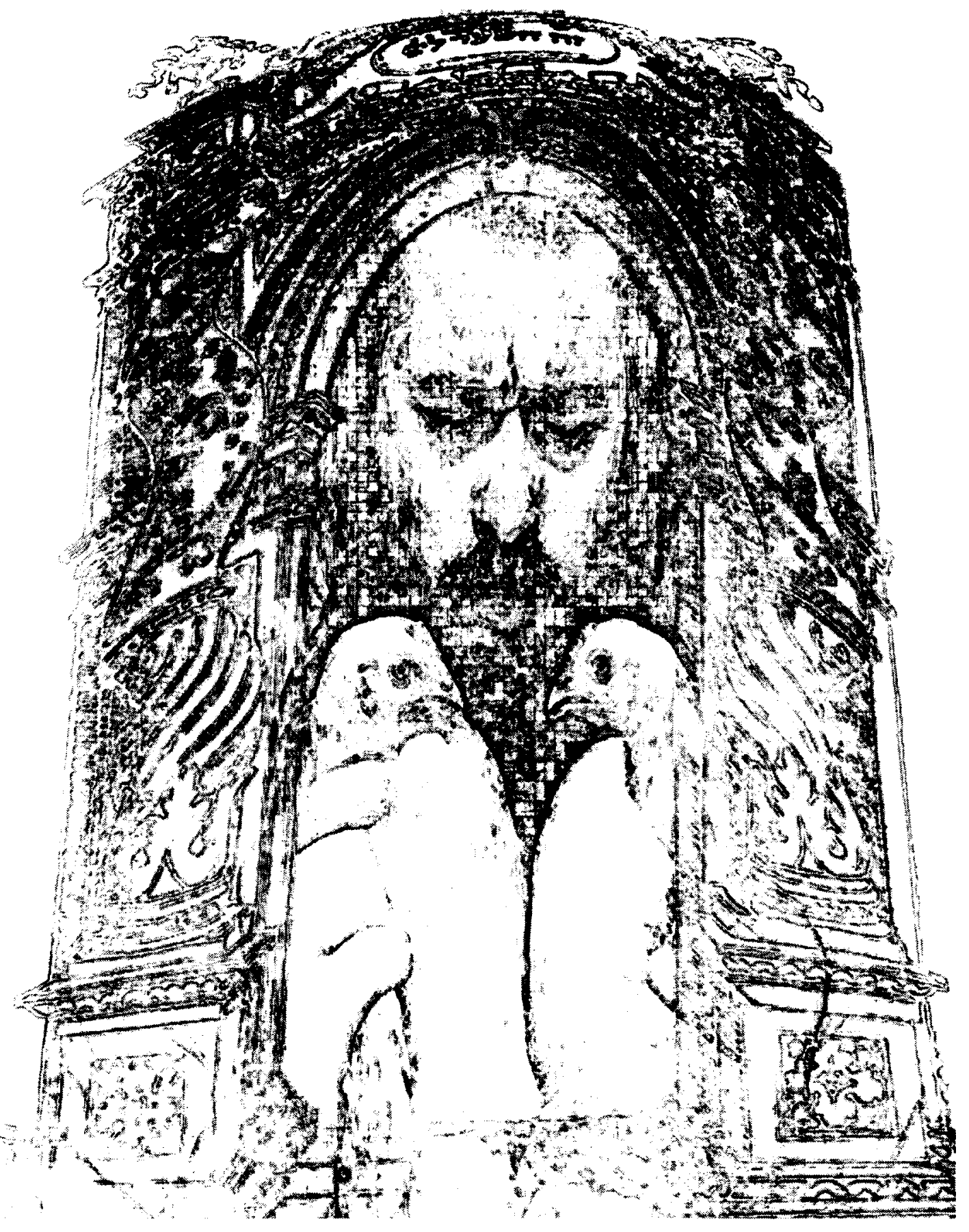




\section{Thesis Abstract}

Considering the complexity of Jewish history, religion, and politics, is it possible to propose a contemporary Jewish architecture?

By weaving elements of modern design practice with spatial concepts drawn from Jewish tradition, this thesis will explore new methods of drawing architecture intrinsically rooted in Torah and Jewish Culture.

This investigation is centred on the many guises of "Bezalel". From a biblical perspective Bezalel (the persona) offers a connection to the deep architectural roots that are intrinsic to the tradition of the Torah and Jewish culture. On the other hand, is the allegory of a divine relationship with architecture relevant in modern Israel? To address this question, the allegorical facets of Bezalel the biblical architect are tested within the context of a design competition for Jerusalem's Bezalel Academy of Arts and Design. By transposing the contemporary Jewish compositional approach of musical composer John Zorn to the realm of architecture, I offer a proposal for a new Bezalel (the academy) that addresses the tension between the latent metaphysical aspects within Jewish tradition and the realities of modern Jerusalem. 


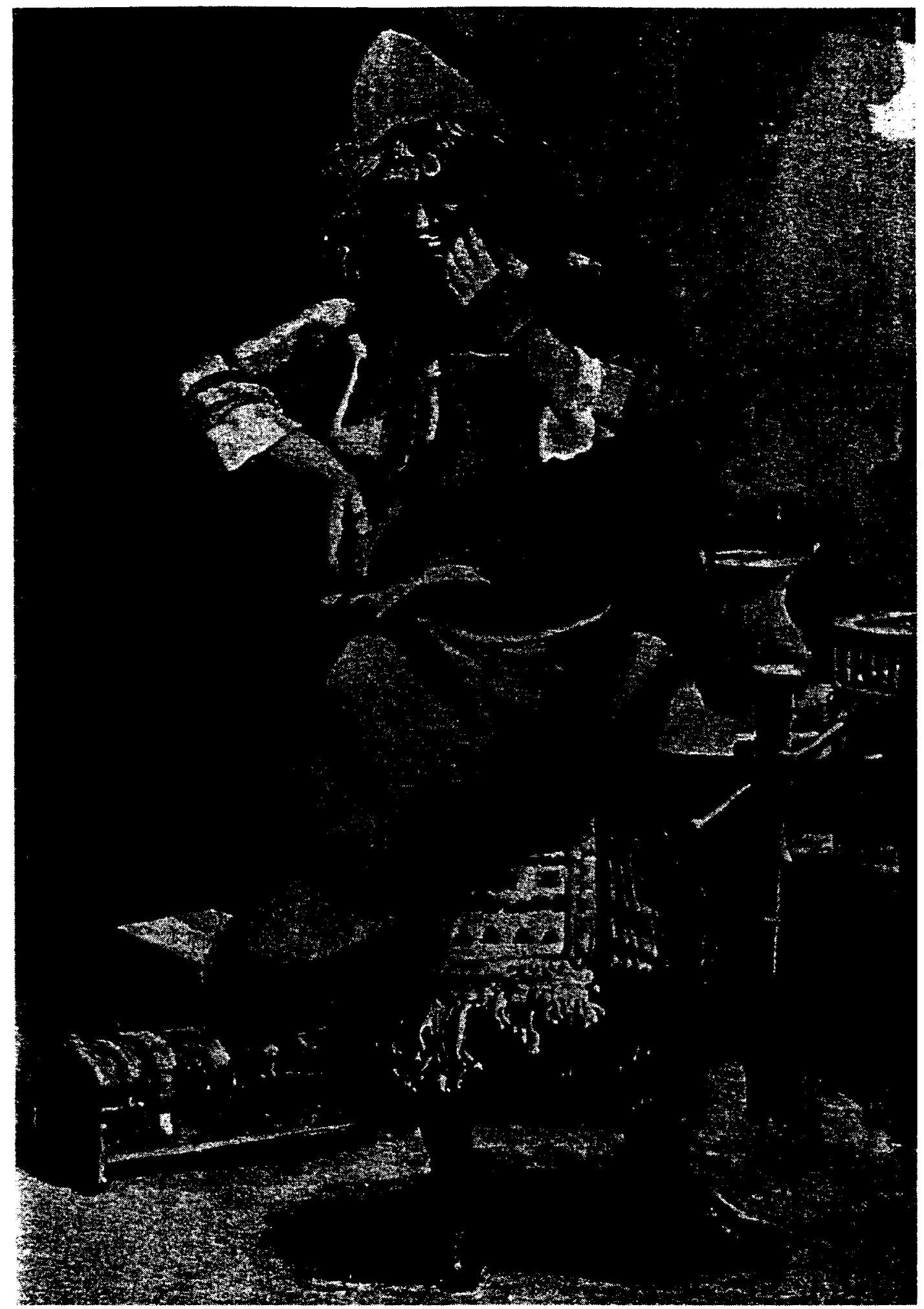

Figure - 2 / Bezalel - as in Exodus 31. Watercolour by James Tissot

Source: $h t t p: / / w w w . w c g . o r g / i m a g e s / b 2 / b 2 v \% 20(20) . j p g$ 


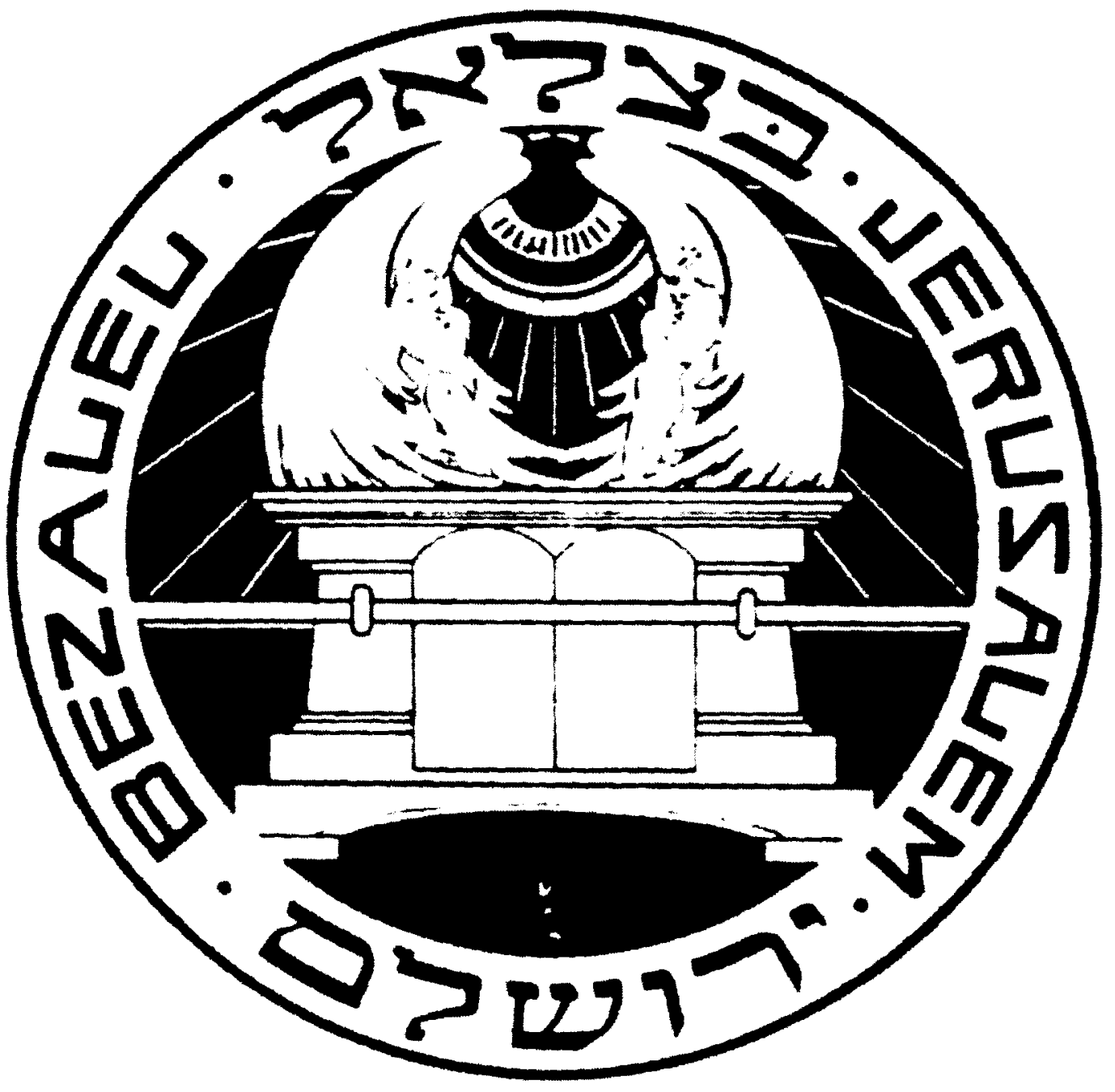

Figure - 3 / Logo for the Bezalel Academy of Art and Design.

Source: $h t t p: / / u p l o a d . w i k i m e d i a . o r g / w i k i p e d i a / e n / a / a 2 / B e z a l e / 11 . j p g$ 


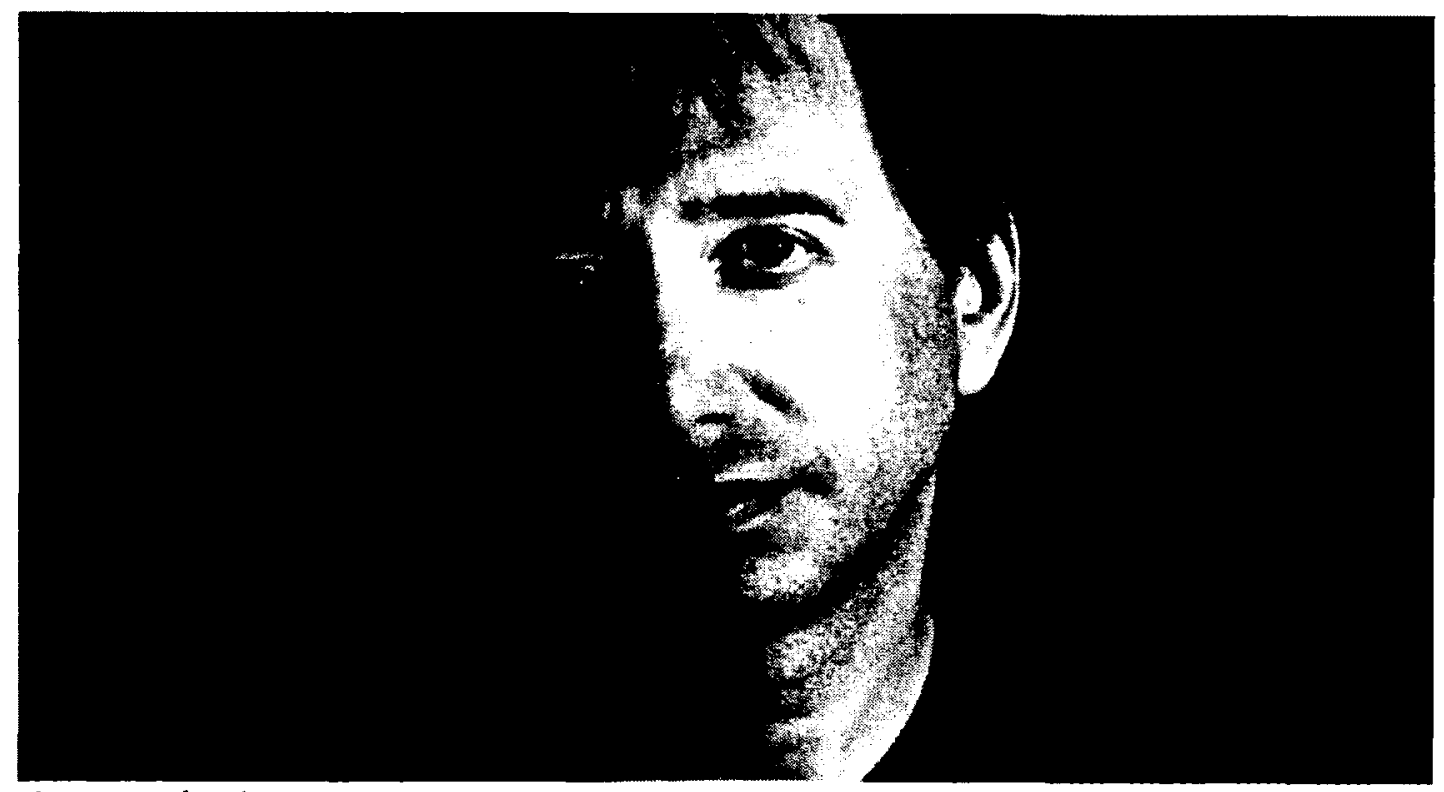

Figure - 4 | John Zorn,

Source: http://indiemusic.co/files/2011/12/John-zorn_wide.jpg 


\section{Prologue}

The research and design proposal realized in this document took place predominantly at the Technion - Israel's Institute of Technology - Haifa. Field excursions were also made to Zefat, Odessa, Tel Aviv, Petra, Rosh HaNikra, Tiberias, Sinai and Jerusalem. Several notable events took place throughout the year and half in the Middle East: In June of 2011, the boycott on household cottage cheese began, and further escalated into a national movement related to the cost of living and its relationship to societal values in Israel. September 2nd 2011, Turkey expelled its Israeli ambassador. September 9th 2011, thousands of Egyptian protesters broke into the Israeli embassy in Egypt, the staff was eventually saved by Egyptian soldiers after US president Barack Obama intervened. October 5th 2011, Technion Chemistry Professor Daniel Shechtman won the Nobel Prize for Chemistry for the discovery of quasicrystals. On October 18th 2011, Israeli soldier Gilaad Shalit was released from Hamas captivity in exchange for 1,027 prisoners. January 2012, a mid review was conducted on the progress of the thesis in front of a panel of Carleton School of Architecture Professors and critics. February 2012, I attended Ecoweek in Jerusalem where my group of Israeli, Palestinian, and International architecture students worked on two projects in the West Bank. March 2012, Israeli Defence Forces assassinated three Palestinian militants believed to have been responsible for the 2011 Israeli southern border attacks. Palestinian militants retaliated by firing over 300 
missiles at southern Israeli targets. May 2012, despite a sore ankle and lack of training, I ran the municipal ten kilometer run in Haifa amongst Israeli sailors and Palestinian nationalist supporters. July 2012, thesis defended in front of a panel of Technion Professors and local architects. August 2012, returned to Canada on a Polish airline. September 2012, thesis defended in front of a panel of Carleton Professors. All of these proceedings have had influence on the decisions made throughout this project. 


\section{Table of Contents}

01 Title Page ...

02 Frontispiece ii

03 Thesis Abstract iii

04 Prologue vii

05 Table of Contents. ix

06 Introduction

07 The Project:

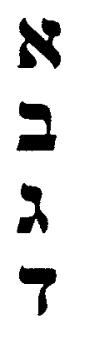

The Hebrew Letters

a Bezalel, The Academy 20

$\lambda$ Bezalel, The Biblical Persona

Design Interventions In Theory 37

- The Space Between The Letters

- Geometry Of The 231 Gates

- Spacing By Cantorial Notation - Inherent Arch Proportions

-Light Through The Proportions Of The Letters

7 The John Zorn Approach ..................................... 80

1 Design Interventions In Practice 84

- Hidden Between The Letters of Bezalel

- Oholiab, Theoretical and Geometrical Support

- Circulation N'ginot

- Seal Of Solomon Imbedded In The Heart

- The Wrapping And Projecting Of Halachic Light

yy Shabbes Cholent

08 Bibliography

09 List of lllustrations

10 Acknowledgements 


\section{Introduction}

The contents of each section of the following chapter (The Project) are written in a way where items stated in previous section(s) are built upon creating an amalgamated end result. The Project is divided into seven sections where the first sections ( $\boldsymbol{*}$. The Hebrew Letters, 2. Bezalel, The Academy, ¿. Bezalel, The Biblical Persona, т. Design Interventions, ה. The John Zorn Approach) contain content supporting the sixth section ( $\%$ Design Interventions In Practice). The sixth section defines the application of the Design Interventions (section r.): i. the space between the letters, ii. geometry from Kabbalistic tradition, iii. from cantillation to architectural space, iv. proportions of inherent Judaic forms, v. wrapping the project in light. These interventions are used to resolve and dissolve pragmatic requirements defined in the Bezalel Academy competition brief. The Seventh and final section (w. After Thoughts) furthers ideas defined in the previous sections.

The ongoing, contextually rich Bezalel Academy of Design competition has a strong potential relationship with contemporary Jewish architecture. The Bezalel Academy of Art and Design, plans to build a new facility. The Academy is undergoing a process of designing a facility that houses an institution priding itself in developing a contemporary culture of Jewish Art and Design. In developing my thesis on contemporary Jewish architecture, I will utilize the competition brief for the Academy as a set of 
guidelines. Additionally, Bezalel, the biblical figure that the Academy is named after, being mentioned in the book of Exodus as the master builder named by God to build the Mishkan, adds a deeper layer of relevance to both the efforts in investigating the hidden spatial qualities of the Hebrew alphabet and in being the figure within the Torah named as God's Architect.

The design interventions rooted in traditional Jewish symbolism will be described pointing to the Parsha (Torah portion) which reveals the naming of Bezalel. As a structure for applying these interventions, the proposal includes using John Zorn's methods for musical composition in developing the plan for Bezalel, the Academy. It is intended that these design components will create a foundation for supporting future pursuits in an effort to create a contemporary Jewish architecture.

There exists a general consensus within the varying streams of Judaism related to the importance of the Hebrew letters, the foundation of the Torah. The traditional history pointing to a belief in the metaphysical attributes contained within the form, the names, and the number values of these Hebrew letters, suggests that a conceptual use of these letters may be a relevant beginning in designing space for a contemporary Jewish tradition. By expanding on the qualities of the Letters that the Rabbinic tradition holds of utmost value we are generating a platform for discussion 
and illustrating a depth of value in other streams of Jewish society that maintain the use of these letters. The Hebrew letters will be examined within the domain of allegory as tools of creation. The Hebrew letters contain three dominant hidden qualities that support, within Rabbinic tradition, Judaic allegories. These three hidden qualities are as follows: the names of the letters possessing related meaning, the letters being attached to a numerical system which in the context of the Torah reveals unforeseen associations, and lastly the importance in maintaining the form and proportion of the letters due to concepts inherent within them. These qualities when examined in further depth produce a number of architectural opportunities for consideration in design application.

The Competition for the new Bezalel Academy is an appropriate architectural program for exploring the nature of contemporary Jewish Architecture. The location of the Academy in Jerusalem, the importance of that city for Jewish culture both nationally and internationally points to Jerusalem as the geographical centre of Jewish identity. But beyond the larger political and cultural context, the site has a number of qualities specific to the unique urban qualities of Jerusalem and the city's complex social demographic. When examining the curriculum of the Academy, there is a clear emphasis on developing and refining a culture of Jewish art and design. Yet, the Competition Brief speaks of a common truth in 
the architectural development of today, where those making decisions and providing funding focus on creating spaces that function, conform, and produce. This reality is such that a relationship to Jewish culture of Art and Design is a secondary thought. The tension between what is required from those operating and using the building and the importance of the underlying architectural language is a defining factor in realizing contemporary architectural work. It is by means of this tension and the accompanying contextual factors that the project will build measured relationships between the required pragmatic design of the Academy and the metaphysical qualities of contemporary architectural interventions related to Jewish tradition.

By selecting the new Bezalel Academy as a project, and by proposing an experimentation in Jewish Architecture one cannot overlook the biblical character of the school's name. Bezalel, the master builder of the Tabernacle, or God's architect, is first mentioned within the Torah in the 31st chapter of the book of Exodus. The association of the school to the name Bezalel is not only interesting within the domain of identifying a Master builder from the perspective of the Torah, but also the tradition of belief associated with Bezalel's ability to create using certain combinations of the Hebrew letters. Additionally, the multiple meanings of the name Bezalel point to further metaphoric design creations. 
Using the cultural context of the chosen project, the hidden meanings associated with the Hebrew letters, and the Biblical character which the Academy takes its name, design interventions will be proposed rooted in themed Judaic architectural association. The letters of Bezalel's name are proposed as a the unifying element of the design, while the structure supporting this intervention will reflect the supporting character Oholiab (from Bezalel's allegory in the book of Exodus). The notation used during the cantillation of the allegory of Bezalel within a typical Synagogue service will act as a guideline for programmatic spacing, while symbols found on the gates of the neighboring old city of Jerusalem will be used as tools in creating structural proportions connected to a cultural relationship with the city. Finally the building will be wrapped in a curtain wall with apertures determined by the letters revealing the character of Bezalel in the Torah. These five interventions are proposed as experiments in applying Judaic concepts to architectural realities.

Lastly, the writing process of contemporary musician John Zorn's project in "Radical Jewish Culture" will be identified. Zorn's structure in composing music is to be transcribed as a guiding configuration in applying metaphysical ideas to the pragmatic architectural requirements. Zorn's ability to summon traditional Jewish musical ideas and apply them within a contemporary context has a value of translation within other 
mediums. This understanding in bridging what is traditional and what is contemporarily relevant is specifically interesting when considering the application of the mentioned design interventions within the architectural programmatic requirements of the building.

The following chapters will describe experimentation in the above mentioned design components: the Hebrew Letters, the project for the new Bezalel Academy of Art and Design, Bezalel the biblical character, the proposed design interventions, and John Zorn's method of combining the traditional with the contemporary, and lastly the integration of the proposed interventions with. These components will remain central to this investigation in a contemporary Jewish architectural language. 
07 The Project 


\section{The Hebrew Letters}

The Torah, according to Jewish tradition, refers to the five books of Moses (בראשית-In the Beginning [Genesis], שמות-Names [Exodus], ויקרא-He Called [Leviticus], במדבר-In the Desert [Numbers], and דברים-Words [Deuteronomy]). Within certain steams of Jewish belief, these texts are thought to have been given from God directly to Moses. At the root of the Torah's design are the letters which some believe is a divine script design received by the Israelites from God. In the section, in Cara Goldberg Marks book on Hebrew calligraphy, discussing the typical script used for inscribing the Torah (K'Tav Ashuri), mention is made of Moses receiving the Torah and the taggin (crown details on the letters) directly from God:

"The Talmud tells us that when Moses climbed to Heaven to be taught the Torah and receives the Tablets of the Jews, he saw God putting crowns on the letters."

Goldberg Marks mentions this specific detail from the Torah script (the taggin) as being designed by God for future generations. This points to the hidden levels of understanding related to the forms of the scripture, where unique messages may only reveal themselves within specific generations and geographies.

\footnotetext{
${ }^{1}$ Goldberg Marks, Cara. The Handbook of Hebrew Caligraphy Northvale, NJ: Jason Aronson Inc. 1995, pg.68
} 
"Rav Yehuda said in the name of Rav, When Moses ascended on high [to receive the Torah], he found the Holy One, blessed be He, sitting and tying knots (taggin) on the letters. [Moses] said to Him: Lord of the Universe, what are those for? He replied, After many generations a man will be bom called Aqiva ben Joseph; he will infer stacks of laws from each of these marks. "

This passage from the Talmud points to the condition that even the smallest of details contained within the spacing and the shape of the letters not only have potential significance for current Jewish scholars but may include messages that remain dormant within the text until the appropriate generation or context presents itself. Partially due to these beliefs, the maintenance of the script is of such importance that Rabbinical tradition has developed a series of regulations to preserve the kashrut of a Torah Scroll. These regulations are as follows:

"-A Torah Scroll is disqualified if even a single letter is added.

-A Torah Scoll is disqualified if even a single letter is deleted.

-The scribe must be a learned, pious Jew, who has undergone special training and certification.

-All materials (parchment, ink, quill) must conform to strict specifications, and be prepared for the purpose of writing a Torah Scroll.

-The scribe may not write even one letter into a Torah Scroll by heart. Rather, he must have a second, kosher scroll opened before him at all times.

\footnotetext{
${ }^{2}$ Solomon, Norman. The Talmud A Selection London, UK: Penguin Classics, 2009, pg.591
} 
-the scribe must pronounce every word out loud before copying it from the correct text.

-Every letter must have sufficient white space surrounding it. If one letter touched another in any spot, it invalidates the entire scroll.

-If a single letter was so marred that it cannot be read at all, or resembles another letter (whether the defect is in the writing, or is due to a hole, tear or smudge), this invalidates the entire scroll. Each letter must be sufficiently legible so that even an ordinary schoolchild would distinguish it from other similar letters.

-The scribe must put precise space between words, so that one word will not look like two words, or two words look like one word.

-The scribe must not alter the design of the sections, and must conform to particular line-lengths and paragraph configurations.

-A Torah Scroll in which any mistake had been found cannot be used, and a decision regarding its restoration must be made within 30 days, or it must be buried. ${ }^{13}$

In other words, the form and the proportion of the letters found within the Torah and the tradition of preserving this method of inscribing is of significant importance. Additionally the literal names signifying each of the Hebrew letters add to this importance in maintaining form and proportion. If we consider the literal name of the first Hebrew letter " $"$ " (pronounced "אל-Aleph"), one is met with a number of definitions. A definition of the word means to learn, while another means to produce thousands (in

\footnotetext{
${ }^{3}$ Aish HaTorah's Discovery Seminar. The great success of Jewish tradition is the meticulous transmission of the Torah text. But actually how accurate is it? Internet: http://www.aish.com/h/sh/tat/48969731.html, May 14, 2002 [July 27, 2012]
} 
modern Hebrew the word for the number 1000 is spelt in the same manner), and yet another definition points to the term "master".

"The root אלף is rare and means to learn or to teach but perhaps not in a very good way (Prov 22:35, Job 15:5, 33:33, 35:11). The identical word אלך means to produce thousands (Ps 144:13 only) it

Beyond the ability of the letters to combine, leading to words, which combine to form sentences, and further to form parables, at the root of these letters exists relationships intertwined with associative and numeric symbolism (גימטריה-Gematria). Gematria is a system where numerical values are attributed to each Hebrew letter and that by treating the combination of letters as numerical values one can determine relationships between other words with equal and/or related numerical values. [see figure: 5]

If we reconsider the example of Aleph by using the definition of Master in combination with the Gematria definition of 1 , a metaphor reflecting the important Jewish belief in one deity unfolds:

"ALEF ... Name: Oxen; thousand; teaching; master...Divinity 'Master of the universe.' The Divine 'One' revealing itself throughout the plurality of Creation. ${ }^{15}$

\footnotetext{
${ }^{4}$ Uittenbogaard, Arie. The Hebrew Alphabet-On the meaning of the Hebrew Alphabet Internet: http://www.abarimpublications.com/Hebrew_Alphabet_Meaning.htmI\#.UBLNb7StLKd, [July 27, 2012]
} 
This example points to a layered understanding where the perspective of comprehension comes from a place of core beliefs centred around a strong connection and commitment with monotheism. Although not all the letters relate to this aspect of the theological theories, it is evident that this system of interpretation was generated from the monotheistic perspective.

By Additionally exploring the messages found within the system of Gematria, one will notice a deeper connection to the allegories present at the literal level. For example; consider the word for father(אב-Av) and the word for mother (א-Em), and one will notice that the numerical value for the two combined equals the word for child (ילד-Yeled). [see figure: 6]

The third form of considering interpretation for each individual Hebrew letter is specifically related to the form and the message behind what the form is communicating. In most cases each Hebrew letter is composed of a series of other Hebrew letters, further layering the complexity of interpretation. Consider once more Aleph: the letter Aleph is made up of one upside down "1" (Yud), one right side up "1" (Yud), and a diagonal "1" (Vav).

\footnotetext{
${ }^{5}$ Ginsburgh, Rabbi Yitzchak. The Hebrew Letters Channels of Creative Consciousness Rechovot, Israel: Linda Pinsky Publications, 1992, p.26
} 
"ALEF (א) FORM: $\quad$ A yud (') above and a yud (') below with a vav (I)

separating and uniting them simultaneously.

The secret of the "image" in which man was

created. ${ }^{n 6}$

In Rabbi Yitzchak Ginsburgh's book on Hebrew Letters, he takes note of the abstract formal qualities of each of the letters and their relationships to the dogmatic Jewish beliefs. Rabbi Ginsburgh divides these relationships of form into three realms: Worlds, Souls, and Divinity. Within each of these realms certain letter to metaphor connections are described. For Example, within the realm of Worlds, the Aleph is described as symbolic of connections between water, earth, the atmosphere, and our human bodies:

"Worlds

between them.
In the world:
the upper atmosphere, the lower atmosphere,
the atmosphere, the hydrological cycle
In the human body: $\quad \begin{aligned} & \text { The respiratory system, the diaphragm, the } \\ & \text { digestive system, the skull-water, the } \\ & \text { membrane, the brain-moisture }{ }^{\prime 7}\end{aligned}$

\footnotetext{
${ }^{6}$ Ginsburgh, Rabbi Yitzchak. The Hebrew Letters Channels of Creative Consciousness Rechovot, Israel: Linda Pinsky Publications, 1992, p.26

'Ginsburgh, Rabbi Yitzchak. The Hebrew Letters Channels of Creative Consciousness Rechovot, Israel: Linda Pinsky Publications, 1992, p.26
} 
In this sense the multiplicity of symbols that exist within the reading of each letter generates multiple relationships to both the form of the letter its relationship with its adjacent. Through the identification of the form of the letter Aleph containing a relationship with the upper and lower atmosphere in the world, and the letter additionally containing a relationship with the human respiratory system certain scholars will draw conclusions that both the respiratory system and atmospheres have spiritual connections by means of their shared metaphoric relationship within the letter Aleph.

It is also understood from the Rabbinic tradition that at a further spiritual level the letters are the building blocks of creation. Rabbi Dov Ber (the Maggid of Mezritch), one of the leaders of the Chassidic movement, makes a connection to the first sentence in the book of Genesis where it is written in Hebrew:

\begin{tabular}{|c|c|c|c|c|c|c|}
\hline הארץ & ואת & העפמים & את & אלהים & ברא & בראשית \\
\hline taAretz & $V e-E t$ & Hashamayim & $E t$ & Elohim & Bara & Ber \\
\hline arth & And & The Heavens & & God & Created & $\ln E$ \\
\hline
\end{tabular}


The illustrated Hebrew sentence translates as: "In the beginning of God's creating the heavens and the earth -" 8 Comparing the English translation to the transliteration above one notices that the Hebrew word "אתת" isn't defined. Generally within this context, the word "את" is defined as "the sign of the definite accusative"s. In other words, when the verb "created" is indicated to have been accomplished by God the word "את" indicates what was "created" ("The Heaven" and "The Earth").

"Just as the 'word of God' gave being to the heaven, so it is His word that gives being to everything...Rabbi Dov Ber, the Maggid of Mezritch, writes: It is known in Kabbalistic literature that the letters of the AlephBeis were created first of all. Thereafter, by use of the letters, the Holy One, Blessed is He, created all the worlds. This hidden meaning of the first phrase in the Torah, 'In the beginning God created $ת \boldsymbol{x}^{\prime}$ - that is, God's first act was to create from $x$ to $n$ (or Torah). "10

Rabbi Dov Ber has concluded that the word "את" isn't only a definite accusative in this case, but that the Torah in this sentence is suggesting that the Hebrew alphabet, "א" (aleph-the first letter in the Hebrew alphabet) thru "ת" (tav - the last letter in the Hebrew alphabet) came

\footnotetext{
${ }^{8}$ Scherman, Rabbi Nosson. The Chumash (the artscroll series / Stone edition)-The Torah: Haftoros and five Megillos with a commentary anthologized from rabbinic writngs Edited by Rabbi Hersh Goldwurm, Rabbi Avie Gold, and Rabbi Meir Zlotowitz. Brooklyn, NY: Mesorah Publications Ltd, 1993, p. 2

${ }^{9}$ Ben-Yehuda, Ehud and David Weinstein Ben-Yehuda's Pocket English-Hebrew Hebrew-English Dictionary New York, NY: Pocket Books, a division of Simon \& Schuster Inc. 1961, p. 19

${ }^{10}$ Munk, Rabbi Michael L. The Wisdom in The Hebrew Alphabet - The Sacred Letters as a Guide to Jewish Deed and Thought Brooklyn, NY: Mesorah Publications LTD. 1983, p. 19
} 
before the creation of our world. In the statement: "...by use of the letter... He, created all the worlds"(from the reference above) Rabbi Dov Ber is suggesting that God uses the Hebrew letters to create the elements that make up our world.

Rabbi Elazar ben Padat, who headed the Hebrew Academy in Tiberias around the 3rd century of the Common Era, speaks of the Maaseh Merkava as a tool which utilizes these powers of creation. Although Maaseh Merkava is a series of meditative methods used to reach the spiritual realms, the tools used are rooted within the Hebrew Alphabet. Rabbi Elazar was so convinced of their powers that he expressed a theory describing that the Torah was actually out of order, and that should the Torah have been written in order everyone reading Torah would generate an anarchy of creating worlds (like ours) without control:

"Rabbi Elazar thus said, 'The paragraphs of the Torah are not in order. If they were in [correct] order, anyone who read them would be able to [create a world,] resurrect the dead, and perform miracles. " 11

Perhaps the complexity of the relationship to the readings of the Hebrew letters, is somewhat reflective of the greater traditional Jewish method in thinking. Could it be true that at the root level of Judaism, it's letters, one

\footnotetext{
${ }^{11}$ Kaplan, Aryeh. Sefer Yetzirah The Book of Creation San Francisco, CA: Red Wheel/Weiser, LLC, 1997, pg. xx
} 
sees signs of how Judaism understands the complexities of the world? When a letter can be read in a way where the name of the letter, the numerical value, and the proportional form, all point to a multiplicity of meanings and associations, does it not follow that the language and culture (attached to the letters) operate within similar systems of multiple relationships? Furthermore, the most architecturally telling observation behind the spiritual qualities these multiple relationships deals with the suggestion that the letters are used as tools to create our physical world. In the following chapters this theory will be explored in ways of architectural application. 


\begin{tabular}{|l|c|c|c|c|c|c|c|c|c|}
\hline & $\times$ & $\Xi$ & 2 & 7 & 7 & 1 & 9 & T & 0 \\
\hline \hline absolute & $1^{\star}$ & 2 & 3 & 4 & 5 & 6 & 7 & 8 & 9 \\
\hline ordinal & 1 & 2 & 3 & 4 & 5 & 6 & 7 & 8 & 9 \\
\hline reduced & 1 & 2 & 3 & 4 & 5 & 6 & 7 & 8 & 9 \\
\hline
\end{tabular}

\begin{tabular}{|l|c|c|c|c|c|c|c|c|c|}
\hline & & $\Xi$ & 5 & $\Xi$ & $\mathbf{3}$ & $\mathbf{0}$ & $\mathbf{2}$ & $\mathbf{9}$ & $\mathbf{3}$ \\
\hline \hline absolute & 10 & 20 & 30 & 40 & 50 & 60 & 70 & 80 & 90 \\
\hline ordinal & 10 & 11 & 12 & 13 & 14 & 15 & 16 & 17 & 18 \\
\hline reduced & 1 & 2 & 3 & 4 & 5 & 6 & 7 & 8 & 9 \\
\hline
\end{tabular}

\begin{tabular}{|l|c|c|c|c|c|c|c|c|c|}
\hline & $\boldsymbol{P}$ & $\boldsymbol{\eta}$ & $\boldsymbol{y}$ & $\boldsymbol{\pi}$ & 7 & $\boldsymbol{\Xi}$ & $\mathbf{9}$ & $\boldsymbol{\eta}$ & $\boldsymbol{\varphi}$ \\
\hline \hline absolute & 100 & 200 & 300 & 400 & 500 & 600 & 700 & 800 & 900 \\
\hline ordinal & 19 & 20 & 21 & 22 & 23 & 24 & 25 & 26 & 27 \\
\hline reduced & 1 & 2 & 3 & 4 & 5 & 6 & 7 & 8 & 9 \\
\hline
\end{tabular}

"also equals one thousand (the meaning of the letter "alef") Figure - 5 / Gematria Chart. Source: http://www.inner.org/gematria/gemchart.htm 


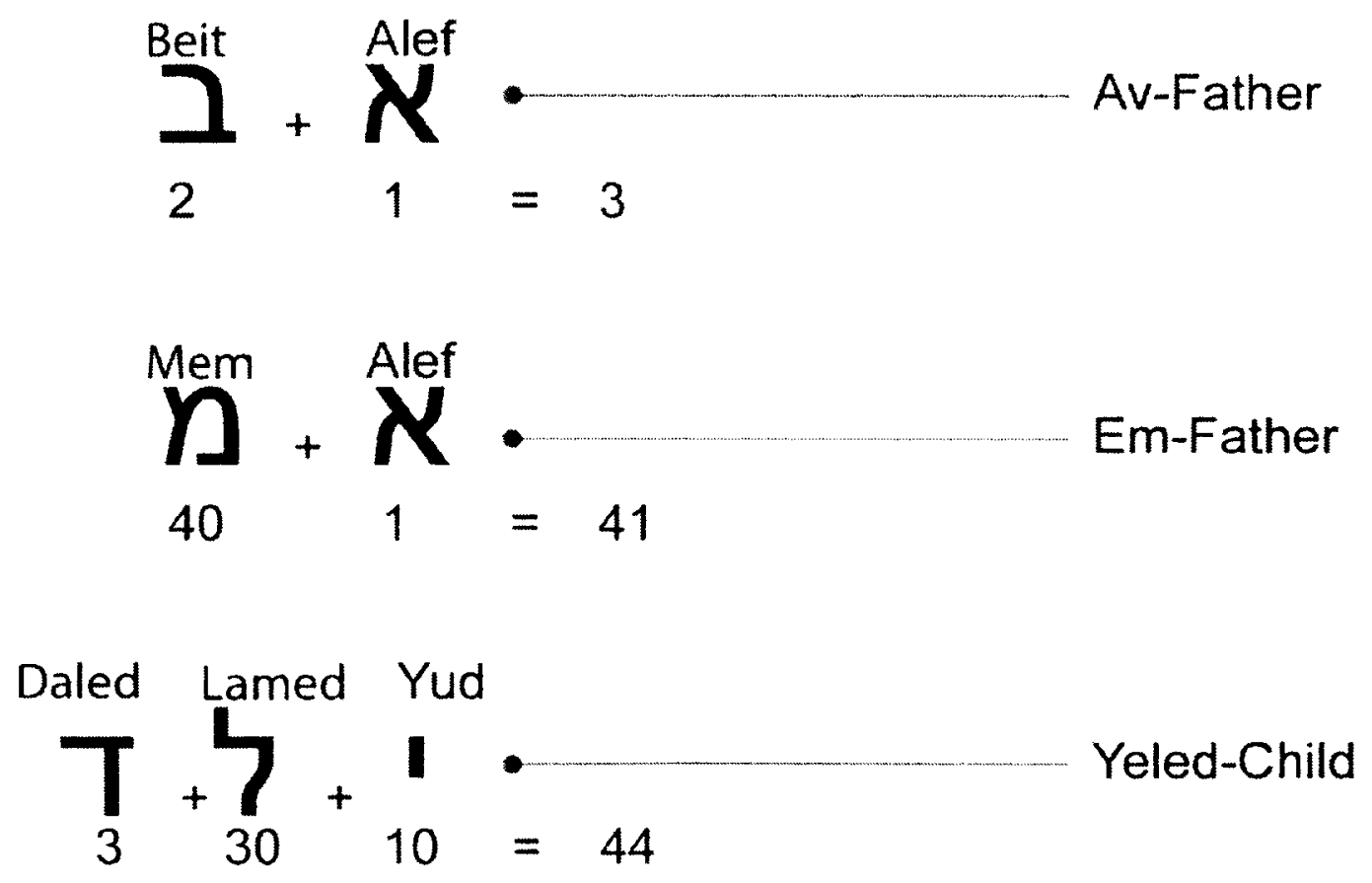

Figure - 6 / Gematria equation for Child. Image by the author. 


\section{: Bezalel, The Academy}

In 2006 the Bezalel Academy of Art and Design launched an international architecture competition for a new school Campus located in downtown Jerusalem's Russian compound neighborhood, Migrash HaRussim. The school intends to amalgamate its current dispersed Jerusalem campus to a unified site encompassing all of the faculties in this central location. This chapter will examine the Academy's relationship to a culture of Jewish Art and design, the factors related to a site in Jerusalem, and the aspects of the competition brief referring to the programmatic requirements of the Academy. The Bezalel Academy brings with it a richness of contextual symbolism and an aspiration in building an institution reflective of the school's efforts in fostering a Jewish contemporary culture of arts and design in Israel.

In 1906 Professor Boris Schatz, established the Bezalel School of Arts \& Crafts. The school's goals are "to train the people of Jerusalem in crafts, develop original Jewish art and support Jewish artists, and to find visual expression for the much yearned for national and spiritual independence that seeks to create a synthesis between European artistic traditions and the Jewish design traditions of the East and West, and to integrate it with the local culture of the Land of Israel." ${ }^{12}$ The identification of Bezalel as a

\footnotetext{
${ }^{12}$ Bezalel Academy of Arts and Design Website Section-About Bezalel>Landmarks Internet: http://www.bezalel.ac.il/en/about/landmarks/, [ June16th 2012]
} 
school with a relationship to the traditions of Judaism seemed of a greater clarity within the work of the students in the initial years of the institution, much of the early work by students, alumni, and faculty have had significant contributions to Jewish Israeli culture in the arts:

Ceramic work by Ze'ev Holtzman [see figure: 7], Illustration work by E. M. Lilien [ see figure: 8], Landscape and portrait artist Hermann Struck [see figure: 9], for example.

In 1952 the State of Israel began quantifiably showing its support for the school. "The government of Israel, aware of Bezalel's historic importance and unique role, begins to provide funding."2 The school has since established itself as one of the top academies for arts within Israel. Much of the work by current students and alumni continue to embrace a relationship with Judaism and the modern Israeli context. Yet reflective of the political situation and modern societal values this relationship becomes less clear:

Photographer Brit Shalit [see figure: 10], Industrial Designer Avi Fadida

[see figure: 11], and Photographer Gidon Levin [see figure: 12].

After a two phase review process, the competition jurors awarded the project to the young architectural practice of STUDYO ARCHITECTs, but 
the public reception of the winning office was met with controversy, and alleged favoritism to international practices.

\begin{abstract}
"Today, the intentions were announced to establish the Bezalel School in the Russian Compound in Jerusalem without having an open public competition among architects in Israel... The location of Jerusalem the capital city, the significance of cultural and social and financial terms, do not allow for ignoring public aspects involved in choosing the Architect and Planners. We urge the Union of Architects to act decisively by appealing to the Minister of Education and the Minister of Culture, in order to preserve the right of every Israeli architect and building designer to have the opportunity in being awarded the work."13
\end{abstract}

What do these claims suggest regarding the Academy's confidence in Israeli architects if preference is given to international firms? This question is especially poignant when one considers the building is to house one of the major architecture schools in Israel. So how can it be that Bezalel remains confident of their architectural education and yet find difficulty in providing equal opportunity for alumni and/or faculty of the institution to design an award winning building for their institution? Due to reasons that remain unclear, in April of 2011 Bezalel's Board of directors decided to dismiss the competition's winning firm, STUDYO ARCHITECTs, and begin

${ }^{13}$ Chyutin, Bracha and Michael Chyutin. ב For the Architectural Competition, Against Bezalel. Hebrew Article from Xnet (translation by the author) Internet: http://www.xnet.co.l/architecture/articles/0,14710,L-3088290,00.html, September 13th 2011 [ April 18th 2012] 
a new tender open to a limited number of architectural offices. In September of the same year, Bezalel announced, not without criticism, the selection of the Japanese Architectural office SANAA to design the new campus. However the President of Bezalel, Professor Anon Zuckerman, assured the public in an article in the HaAretz newspaper that retaining SANAA was the appropriate move:

\begin{abstract}
"Despite the harsh criticism, Bezalel's president, Prof. Arnon Zuckerman, 'is totally at peace' as he put it, with the process and its results. 'Sejima and Nishizawa are among the top 10 best and most exciting architects in the world, in my opinion' Zuckerman said. He was a member of the search committee. 'They are modest and they have very clean and simple lines. In this respect, I think they are more suitable for us than the others, ' Zuckerman said. ${ }^{14}$
\end{abstract}

Although brief, Professor Zuckerman's statement indicates the architectural elements valued most within the selection process: clean, simple lines, modesty, and an international reputation. The decision seems at odds with a school of a century long tradition in training people of Jerusalem in crafts to develop original Jewish art and design while striving for a visual expression of national and spiritual cultural independence.

\footnotetext{
${ }^{14}$ Dvir, Noam Bezalel Academy Picks award-winning Japanese firm to design campus HaAretz Online, Internet:

http://www.haaretz.com/print-edition/news/bezalel-academy-picks-award-winning-japanese-firm-todesignnew-campus-1.383136,

Sept. 08, 2011 [ June 18th 2012]
} 
"Israel's architectural community still regards Bezalel's act as a serious violation of what it sees as the rules of the game: first, because of the institution's decision ultimately to hold a closed tender process, meaning that only firms invited to compete could make bids; and second, because of the decision to award to a foreign firm the job of designing a school that symbolizes the revival of arts and crafts in the Land of Israel. ${ }^{15}$

Even though the decision in selecting an architectural proposal for the new Campus suggests that the school is moving in a more secular, modern, or perhaps anti-nationalistic direction, it also seems that this choice is driven by one of two things selected by the current President: the thirst for having an architectural 'Bilbao' as the new school, or that architecture within the Jewish tradition should act as a backdrop in housing the arts of value. Regardless of these observations, the school remains named after a very poignant figure from the Torah and his relationship to the role of the architect and artisan in Jewish tradition. The school's website quotes verses from Exodus reflective of the importance of its name and its relationship to the schools teachings, in addition the website outlines values in maintaining a tradition of Jewish culture through art and design as fundamental components of the curriculum. Also, the current work of students and alumni, although more vague than years past, do reflect elements of Judaism and Israeli Jewish culture. In light of these finding, it

\footnotetext{
${ }^{15}$ Dvir, Noam 'Starchitecture' vs. homegrown design HaAretz Online, Internet: $h t t p: / / w w w . h a a r e t z . c o m / w e e k e n d / w e e k-s-e n d / s t a r c h i t e c t u r e-v s-h o m e g r o w n-d e s i g n-1.387183$, Sept. 28, 2011[ June 18th 2012]
} 
seems appropriate and interesting in exploring the 2006 Bezalel Academy of Art and Design's international architectural competition as an experiment in Jewish contemporary architecture.

The spaces allotted to each of the twelve faculties which make up the Academy (Fine Arts, Jewelry, Fashion design, Ceramic Design, Industrial Design, Visual Communications, Cinema, Screen-based Arts, Architecture, History and Theory of Art, the Graduate School of Architecture, and the Graduate School of Industrial Design), in addition to the Common Spaces (Auditorium, Library, Computer-Labs, Canteen \& Coffee shop, Sports Facilities, Workshops), and the Functionary Spaces (Management \& Administration, Purchasing, Maintenance, Services), will weave into unison by applying a principle of proto-potential diagramming. Laying out the requirements of the building in relation to the site conditions with a pragmatic strategy, the ordered layout will allow an architectural application of Jewish cultural design principals. In such a way, a design for the new campus could encompass all the contemporary demands of building an Academy of Art and Design in the heart of twenty first Century Jerusalem while being rooted in Jewish Tradition. By building a school that is rooted in Jewish traditional concepts the Bezalel Academy of Art \& Design will begin the built conversation of contemporary Jewish Architecture. 


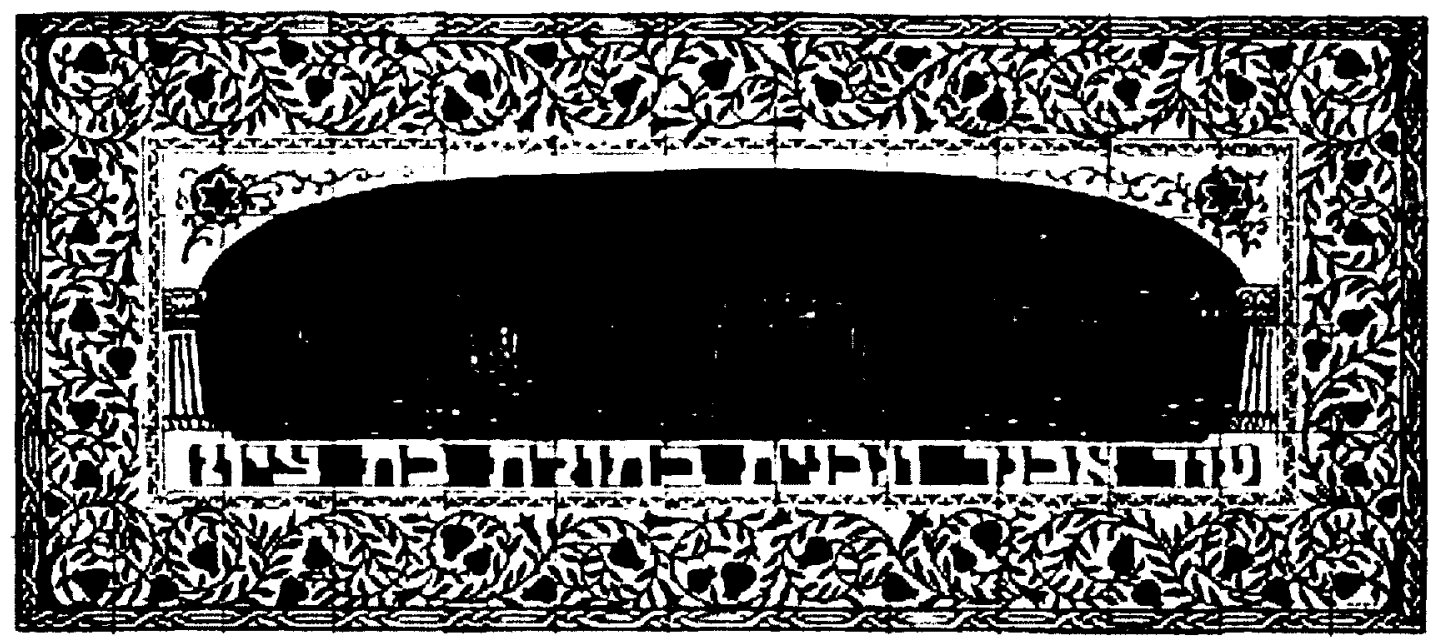

Figure - 7 / Ceramic work by Zeev Holtzman.

Source: http://www.imj.org.il/images/exhibitions/2006/schatz/Slide13.jpg

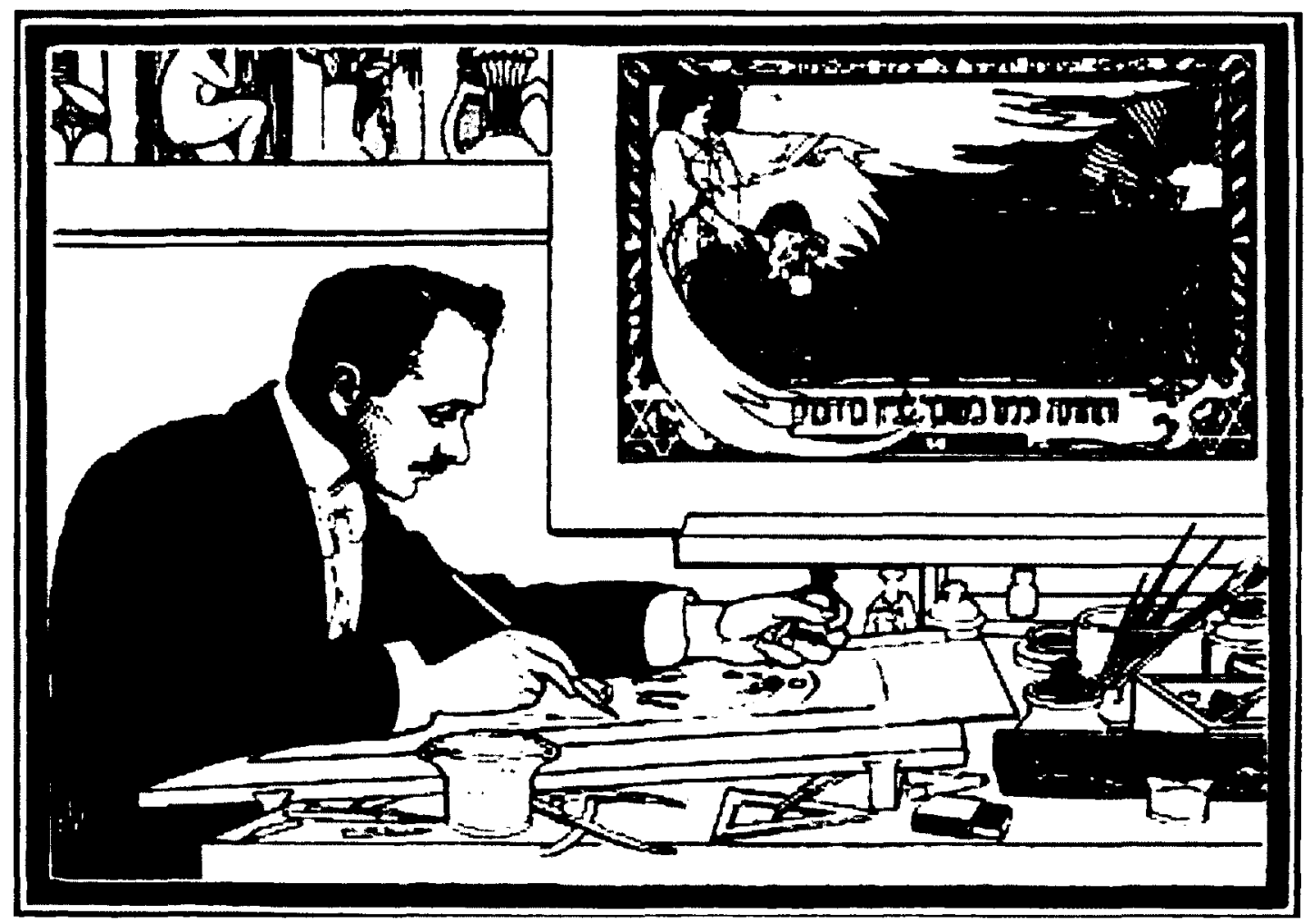

Figure - 8 / Portrait Illustration by E.M. Lilien.

Source: http://www.gwu.edu/ gelman/spec/kiev/expressions/lilien.htm 


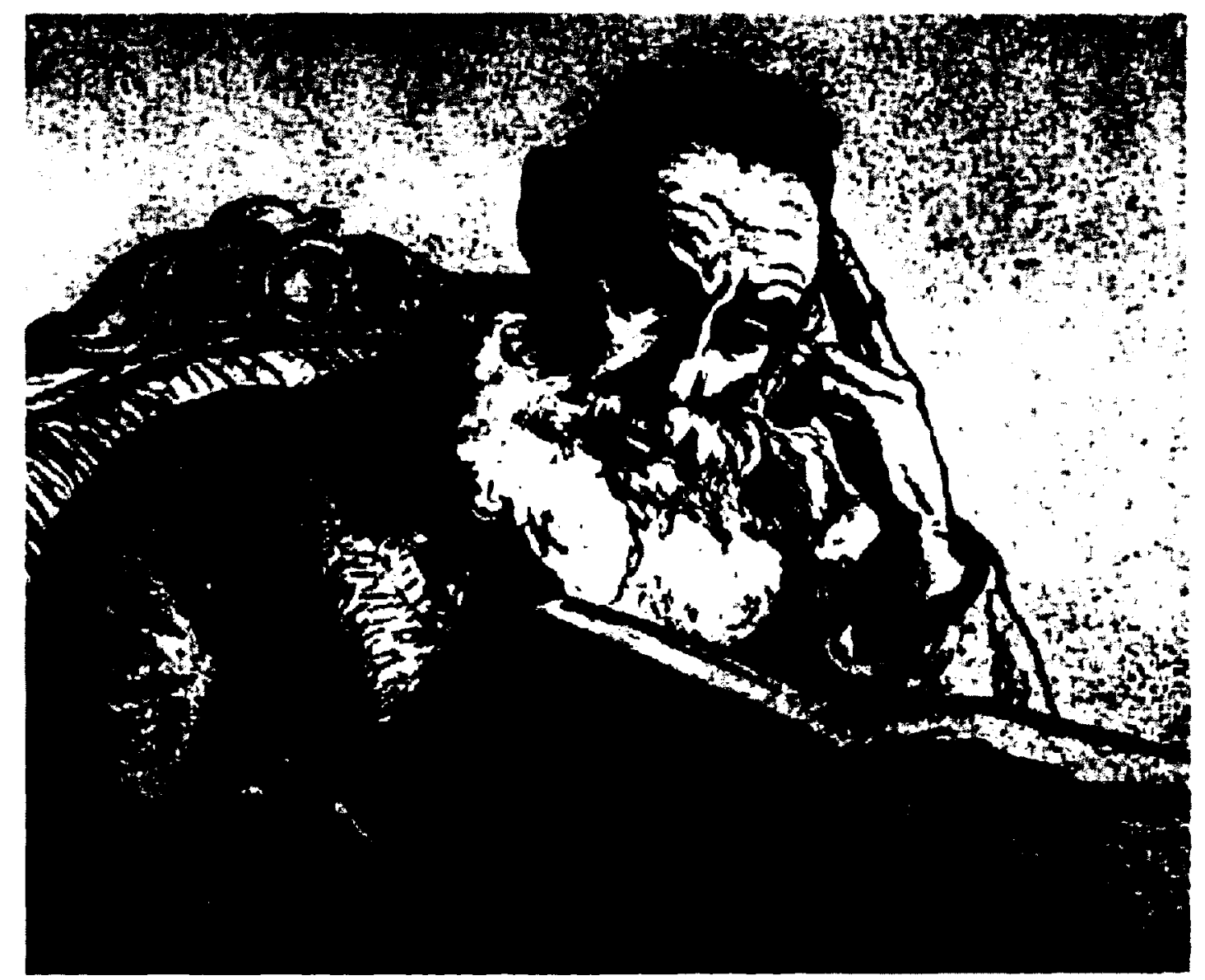

Figure - 9 / IIlustration by Hermann Struck.

Source: $h$ ttp://safed-tzfat.blogspot.co.il/2008/04/el-rostro-de-la-judera-de-laeuropa.html 


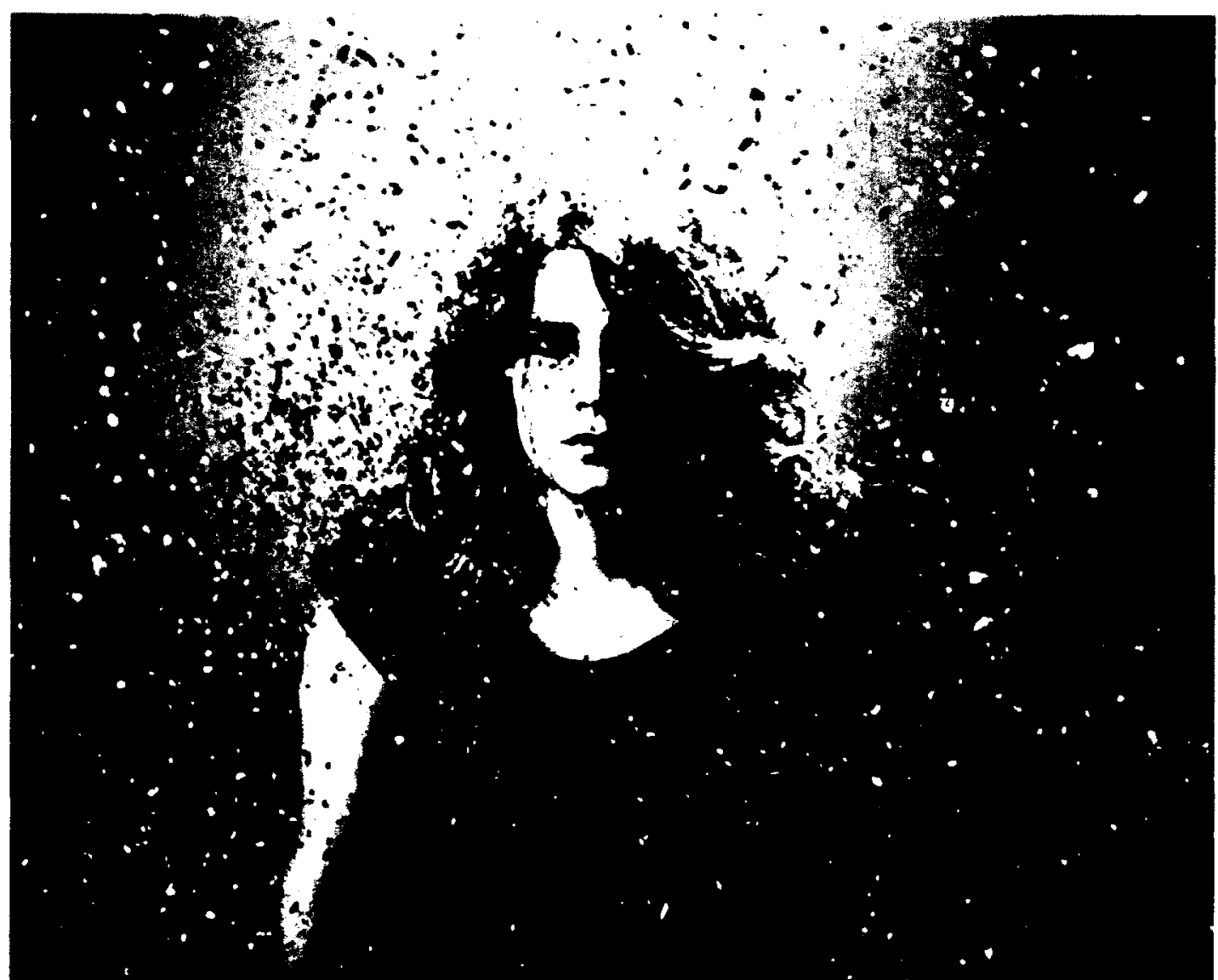

Figure - 10 / Photography by Brit Shalit. Source:

http://www.bezalel.ac.il/en/galleries/54. htm/\#.UFd5il3N-Ao 


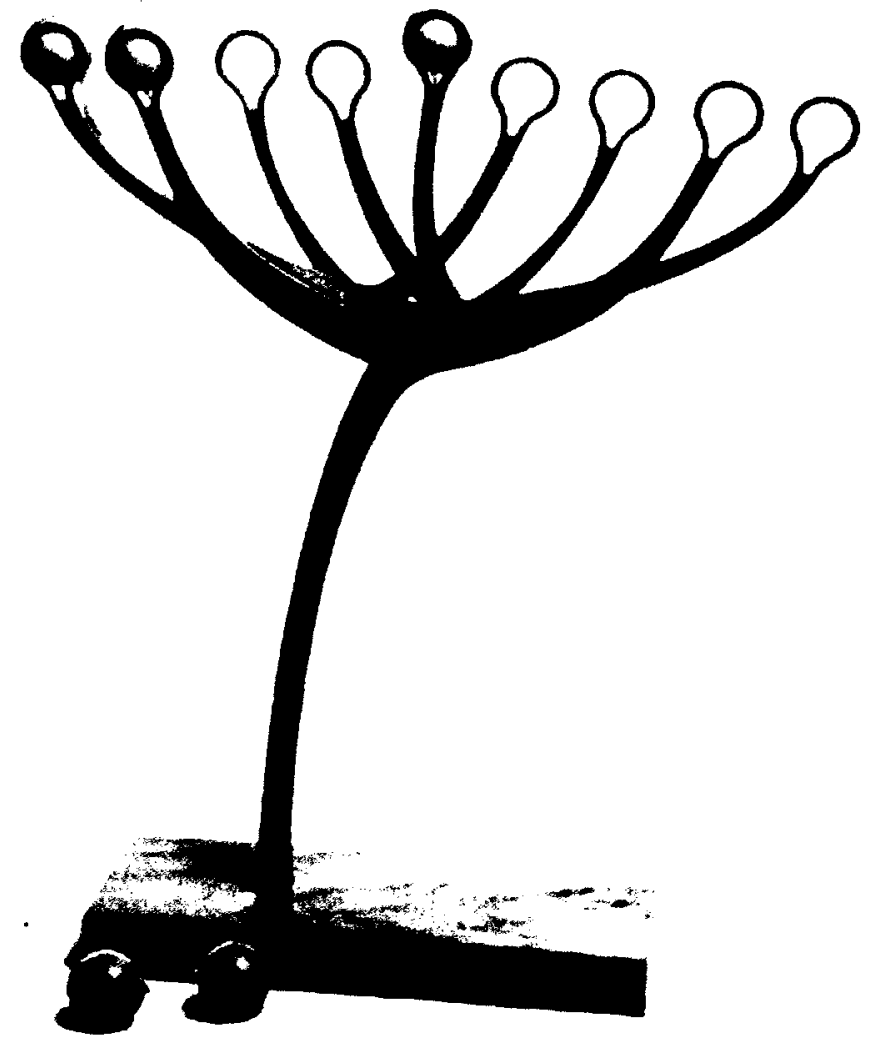

Figure - 11 / Design by Avi Fadida. Source:

http://www.bezalel.ac.il/en/galleries/54.htm/\#.UFd5il3N-Ao 


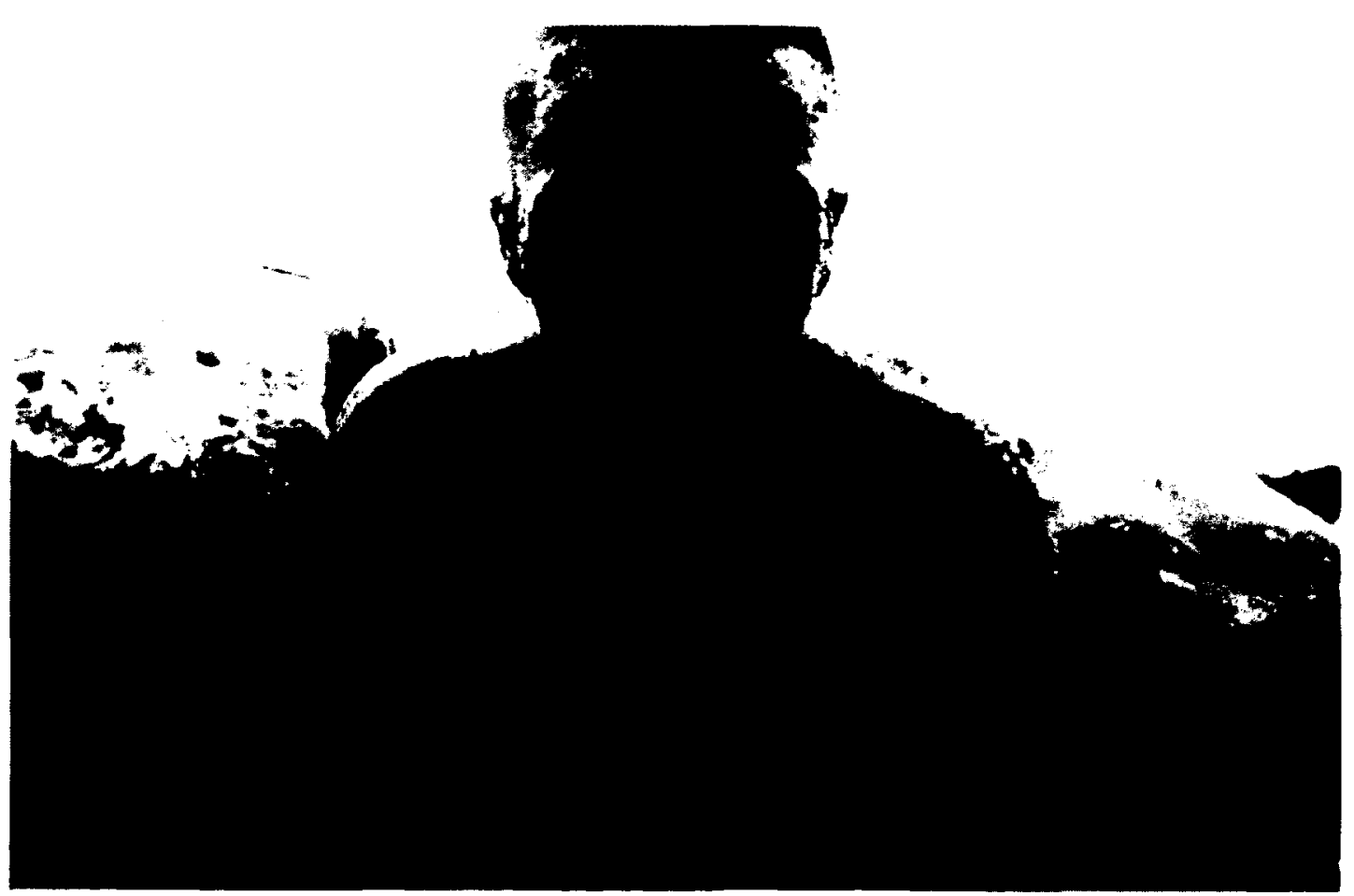

Figure - 12 / Photography by Gidon Levin. Source:

http://www.bezalel.ac.il/en/galleries/54.htmI\#.UFd5il3N-Ao 


\section{: Bezalel, The Biblical Persona}

In the Torah, in chapiter 31 of the book of שמות ("Shmot" - Names/Exodus), God names בצלאל / Bezalel as master builder or chief artisan of the Mishkan (the Tabernacle), it's furnishings and clothing designer:

"See, I have called by name Bezalel the son of Uri, the son of Hur, of the tribe of Judah; and I have filled him with the spirit of God in wisdom, and in understanding, and in knowledge, and in all manner of workmanship, to devise skilful words to work in gold and in silver, and in brass, and in cutting of stones for setting and in carving wood, to work in all manner of workmanship. "16

The first Torah chapter, describing the biblical character of Bezalel (described by some as God's Architect), begins by God suggesting that there is a special quality to the name Bezalel: "See, I have called by name Bezalel..."17 The special quality to the name is understood by God's specific selection of this name for the character. Moreover, Bezalel is to be admired as a symbol, in that not only were the Israelites able to survive the escape from slavery in Egypt but additionally they are able to aspire in creating arts and crafts of greatness.

\footnotetext{
${ }^{16}$ Jewish Publication Society (translator) The Holy Scriptures According to the Masoretic Text Philadelphia, PA: The Jewish Publication Society of America 1916, Shmot Ch. 31 v 2-6, pg. 122 ${ }^{17}$ Ibid. pg. 122
} 
"Bezalel...that he could have mastered the wide array of crafts needed to build the Tabernacle was remarkable, if not miraculous, for the back breaking labor to which Israel had been subjected in Egypt was hardly conducive to the development of such skills...God showed Israel that He had not merely redeemed them from slavery, He had endowed them with the capacity to serve Him beyond their ordinary human potential. ${ }^{18}$

One should take from the metaphor of Bezalel's allegory the life lesson in that it isn't sufficient to survive in our existence, but that in life one should aspire to excellence. Additionally, there are further meanings found within the literal understanding of the name Bezalel. By breaking up the Hebrew letters that make up the word, one can develop new meanings that support the overall meaning of the letters:

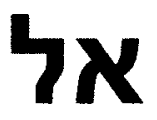

(E)

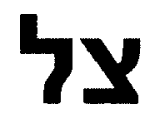

Tzal Shadow

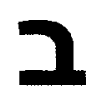

Beh) In the)

In the sense one can also understand the word Bezalel to mean "In The Shadow of God" which could also mean in God's protection. Although, if the first letter was combined with the second word one could also generate this result in interpretation:

\footnotetext{
${ }^{18}$ Scherman, Rabbi Nosson. The Chumash (the artscroll series / Stone edition) - The Torah: Haftoros and five Megillos with a commentary anthologized from rabbinic writngs Edited by Rabbi Hersh Goldwurm, Rabbi Avie Gold, and Rabbi Meir Zlotowitz. Brooklyn, NY: Mesorah Publications Ltd, 1993, pg.489
} 


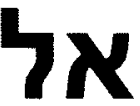

(E)

(God

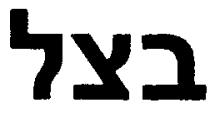

Bzel)

Onion)

Understood as "Onion of God" or "God's Onion", which could suggest Bezalel's multifacetted skill set. Basically, the two interpretations "Onion of God" and "In The Shadow of God" both have poetic factors that reinforce Bezalel's role as God's Architect.

Accepting that the name Bezalel as containing Halachic qualities, it would follow that the use of the name within design could touch upon certain spiritual elements. Gershom Scholem, a German born Israeli Jewish Philosospher, historian, academic scholar of Kabbalah and professor of Jewish Mysticism at the Hebrew University of Jerusalem (See Gershom Scholem [Modern Critical views] by Harold Bloom 1987 \& Gershom Scholem: Kabbalah and Counter - History by David Biale 1982), conducted significant research regarding the metaphysical qualities of the Hebrew letters. Professor Gershom Scholem's research regarding Kabbalists who have used the Hebrew letters as tools for creation, reflects on Bezalel's abilities in combining Hebrew letters. Among the findings to conjure Halachic designs, Scholem writes of Bezalel's powers as the Torah's Ultimate designer: 
"...Bezalel had the highest insight in these matters...for he even knew the right meditations concerning the letters with which heaven and earth are made."19

Bezalel, Scholem advocates, has an understanding in combining letters in order to generate design. To reinforce this theory, one may reconsider the first reference announcing Bezalel within the Torah as God speaks of Bezalel as having been filled:

"... with the spirit of God in wisdom, and in understanding, and in knowledge..."20

Then, by referring to the Book of Proverbs chapter 3 verses 19 and 20: "The Lord by wisdom founded the earth; By understanding He established the heavens. By His knowledge the depths were broken up, and the skies drop down the dew. ${ }^{21}$

This selection from Book of Proverbs describes God's powers of creation as developing from concepts of wisdom, understanding, and knowledge. Thus, if one recalls chapiter 6 section A of this Thesis, that Rabbi Dov Ber

\footnotetext{
${ }^{19}$ Scholem, Gershom On The Kabbalah and Its Symbolism New York, NY: Schocken Books 1965, pg. 190

${ }^{20}$ Jewish Publication Society (translation) The Holy Scriptures According to the Masoretic Text Philadelphia, PA: The Jewish Publication Society of America 1916, Shmot Ch. 31 v 2-6, pg. 122

${ }^{21}$ Jewish Publication Society (translation) The Holy Scriptures According to the Masoretic Text Philadelphia, PA: The Jewish Publication Society of America 1916, Proverbs Ch. 3 v 19-20, pg. 1053
} 
suggests God creates the world using the Hebrew letters, one can also deduct that Bezalel has been given certain similar qualities in being able to utilizes the Hebrew letters as tools to create space. This finding is shared amongst other scholars. In the book "The Energy of Hebrew Letters: The Quantum Story of the Original Alphabet" by Rav P.S. Berg, Bezalel is identified as having such an ability in combining the Hebrew letters to build the Tabernacle:

\footnotetext{
"The Talmud tells us that Bezalel, the ingenious architect, successfully completed the Tabernacle because he "knew how to combine the letters by which the Heavens and Earth were created.' "22
}

By identifying a persona within Torah(Bezalel) as one with a process of creating design using the Hebrew letters, one can take relevant elements from this creation process and apply it to contemporary Jewish design. It seems a focus on the meanings and symbolic values of the Hebrew letters as an initial proposal for contemporary Jewish architecture, would be a step in the appropriate direction.

One approach to contemporary Jewish architecture could use an assemblage of the Hebrew alphabet and it's metaphysical qualities generating a relationship between a certain pragmatic architectural

\footnotetext{
22 Berg, Rav P.S. The Energy of Hebrew Letters: The Quantum Story of the Original Alphabet New York, NY: Kabbalah Centre International, Inc. 2010, pg. 49
} 
approach and in combining Jewish tradition's hidden spatial ideas. In the following chapter a series of design interventions will be explored using spatial and geometrical concepts having connections with Jewish tradition and their potential relationship with contemporary architectural design. 


\section{Design Interventions in Theory}

In this chapter the following five "Jewish" design interventions will be illustrated and examined: i. An exercise in generating Halachic volume by combining contemporary three dimensional modeling software tools and the concept of the written Torah being defined as the space between the letters. ii. Developing a geometry using signified Hebrew words and the Hebrew letter formula of the 231 gates identified in the Kabbalistic text of Sepher Yetzirah. iii. Enlarging the scale of a notation diagram illustrating the trope used as an understanding of pitch when singing the first sentence describing Bezalel in the Torah. iv. Combining the mathematical practice of designing arches through the use of points (for example: the three point arch, five point arch, etc...) and using the points that make up one of the "Seals of Solomon" found on the gates of the Old city in Jerusalem as proportional generators of arches. v. Creating a three dimensional form rooted in the proportions and spacing of the first Parsha which describes Bezalel, in using principals followed by a Sopher when scribing a Sepher Torah in the Ktav Beit Yosef. These design interventions embedded in Jewish theoretical symbolism are described and themed in relationship with the Torah portion that reveals the name Bezalel. The interventions speak of an initial exploration seeking answers to the question: If Torah is the Blueprint of creation what is said about the practice of contemporary Jewish Architecture? 


\title{
i. The Space Between The Letters
}

A basic understanding of Rabbinic belief in Orthodox Judaism highlights the concept of a Written Torah and an Oral Torah. The Written Torah is understood to signify the five books of Moses, while the Oral Torah is understood to encompass the Talmud and all other Jewish traditions passed on through generations orally. In Gershom Scholem's book "On The Kabbalah and its Symbolism", he writes of a passage discussing the theory from Rabbi Isaac the Old who proposes that humanity has yet to receive the written Torah, and that the body of writing understood as both the Written and Oral Torah are actually only the Oral Torah.

\begin{abstract}
"Everything that we perceive in the fixed forms of the Torah, written in ink on parchment, consists, in the last analysis, of interpretations or definitions of what is hidden. There is only an oral Torah: that is the esoteric meaning of these words, and the written Torah is a purely mystical concept. It is embodied in a sphere that is accessible to prophets alone. It was, to be sure, revealed to Moses, but what he gave to the world as the written Torah has acquired its present form by passing through the medium of the oral Torah." ${ }^{23}$
\end{abstract}

Scholem continues to expand on this theory of a hidden Written Torah by describing a treatise from Jacob ben Jacob Kohen, where it is identified that the Written Torah can be found hidden within the parchment contrary

${ }^{23}$ Scholem, Gershom. On The Kabbalah And Its Symbolism New York, NY: Schocken Books Inc. 1965, pg. 50 
to the common understanding that the black letters are the true content of the Written Torah.

"The mystical white of the letters on the parchment is the written Torah, but not the black of the letters inscribed in ink. In the mystical organism of the Torah the two spheres overlap, and there is no written Torah, free from the oral element, that can be known or conceived of by creatures who are not prophets. 24

The theory is architecturally interesting considering what is meant by the Torah of the parchment, such that there is a invisible structure to the Torah supporting the black visible scribed ink. Other sources seem to suggest complimentary themes to this theory. For example, in Aryeh Kaplan's publication of the Bahir (much like the tablets of the Ten Commandments) the letters of the Torah are carved out of an original form, suggesting that Torah has a unified form which the letters aid in illustrating the proportional constraints to define Torah's content:

"... the quarry of the Torah, the treasury of Wisdom, the quarry of the 'spirit of God.' This teaches us that God carved out all the letters of the Torah, engraved it with spirit, and with it made all Forms. This is the

\footnotetext{
${ }^{24}$ Scholem, Gershom. On The Kabbalah And its Symbolism New York, NY: Schocken Books Inc.
} 1965, pg. 50 
meaning of the verse (1 Samuel 2: 2), "There is no Rock (Tzur) like our God" - there is no Former( Tzayir) like our God. ${ }^{25}$

Although contentious, the idea, that the understood Torah of today is only the Oral Torah, speaks of a hidden form inherent within the parchment or the space between the letters. As an exercise in attempting to reconcile what the hidden Torah could be, a series of experiments were conducted by tracing the Hebrew letters according to the proportions of the K'tav Beit Yosef script using the three dimensional modeling software Sketchup. Sketchup operates in a way where by drawing a series of lines and curves, one can achieve a surface should the lines and curves combine creating a closed two dimensional form on the same plane $(X Y, Y Z$, or $Z X$ axis). By using the Sketchup tracing method and attempting to imagine what the hidden Torah between the letters could mean formally, a number of basic geometrical definitions were created with this theory in mind/see figure: 13]. Upon review of the results using Skethup, it was decided to begin further experimentation with a more robust modeling software, Maya. The Sketchup tool, of creating planes by drawing lines to link other co-planar lines or curves, has limitations when considering surfaces which are shifting in more than one plane. Maya (along with similar three dimensional platforms: 3ds MAX, Rhino, Blender, etc...), possesses an ability to generate surfaces in more than a singular two dimensional plane.

\footnotetext{
${ }^{25}$ Kaplan, Aryeh. Bahir: Illumination. Kindle Edition. York Beach, ME: Samuel Weiser, Inc. 1989 (Kindle Location 1528 of 5485 )
} 
The letters were traced within Maya, by using proportionally maintained images scanned from the K'tav Beit Yosef script. Using these scanned images as measured planes in three dimensional space, each letter within a given plane was traced to create a closed curve[see figure: 14]. The "Loft" tool was then selected to create a uniform surface between each of the curves, thereby defining a volume of space among the letters[see figures: 15, 16]. The initial trials produced inaccuracies due to the method of which the Maya Embedded Language (MEL) script defines the loft tool, whereby loft results were created based on the number of verteces (points along the curve) within each letter curve. It was determined that if two different letters had an unequal number of verteces the loft result would be somewhat unpredictable [see figure: 17 ], but by pre planning the number of verteces to be equal with the letter requiring the most verteces one could achieve a more predictable Lofting result[see figures: 18,19$]$. This method of creating three dimensional volumes of space could be applied to any written concept within the Torah, by selecting the associative word or phrase. In the successive chapters, an exploration of the method within an architectural application will be explore. 


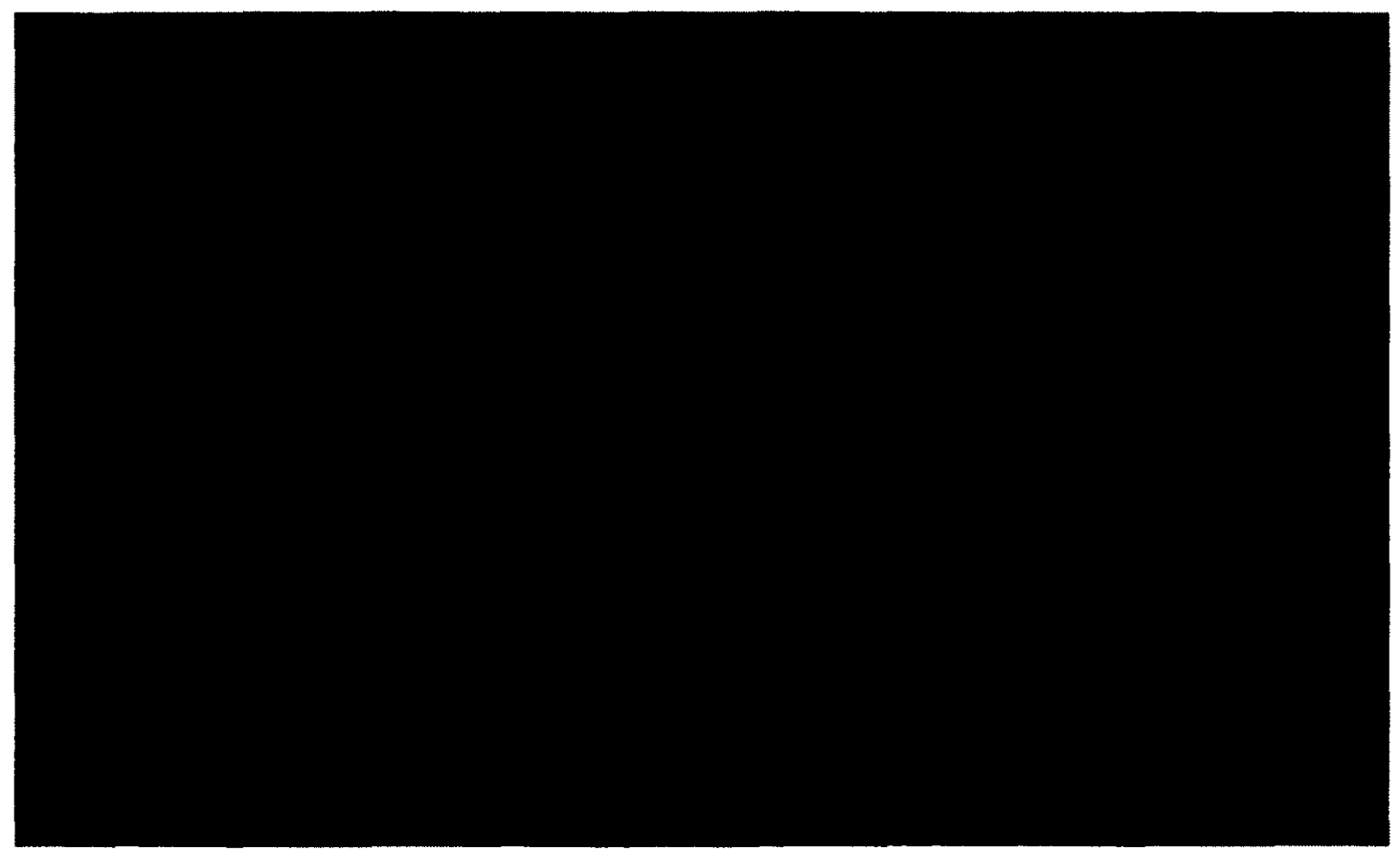

Figure - 13 /Sketchup method: Hebrew word 'Makom' (space) 


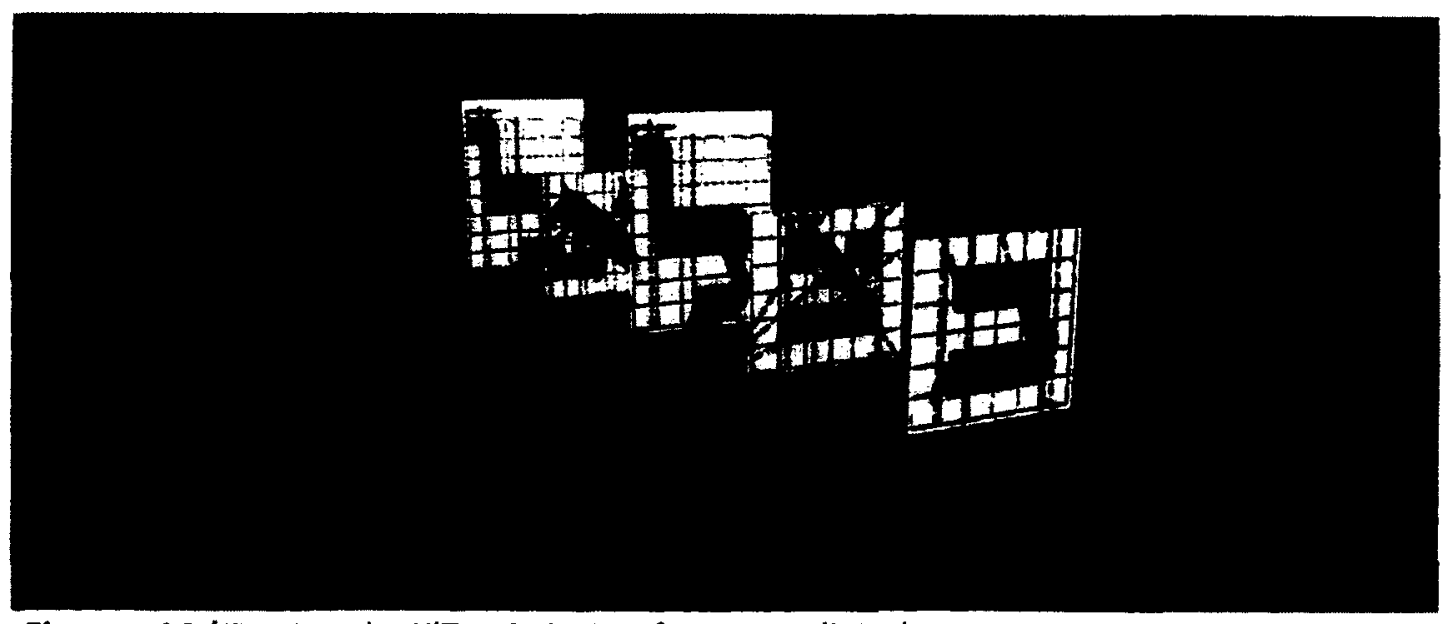

Figure - 14 / Tracing the K'Tav Beit Yosef script in digital space. 


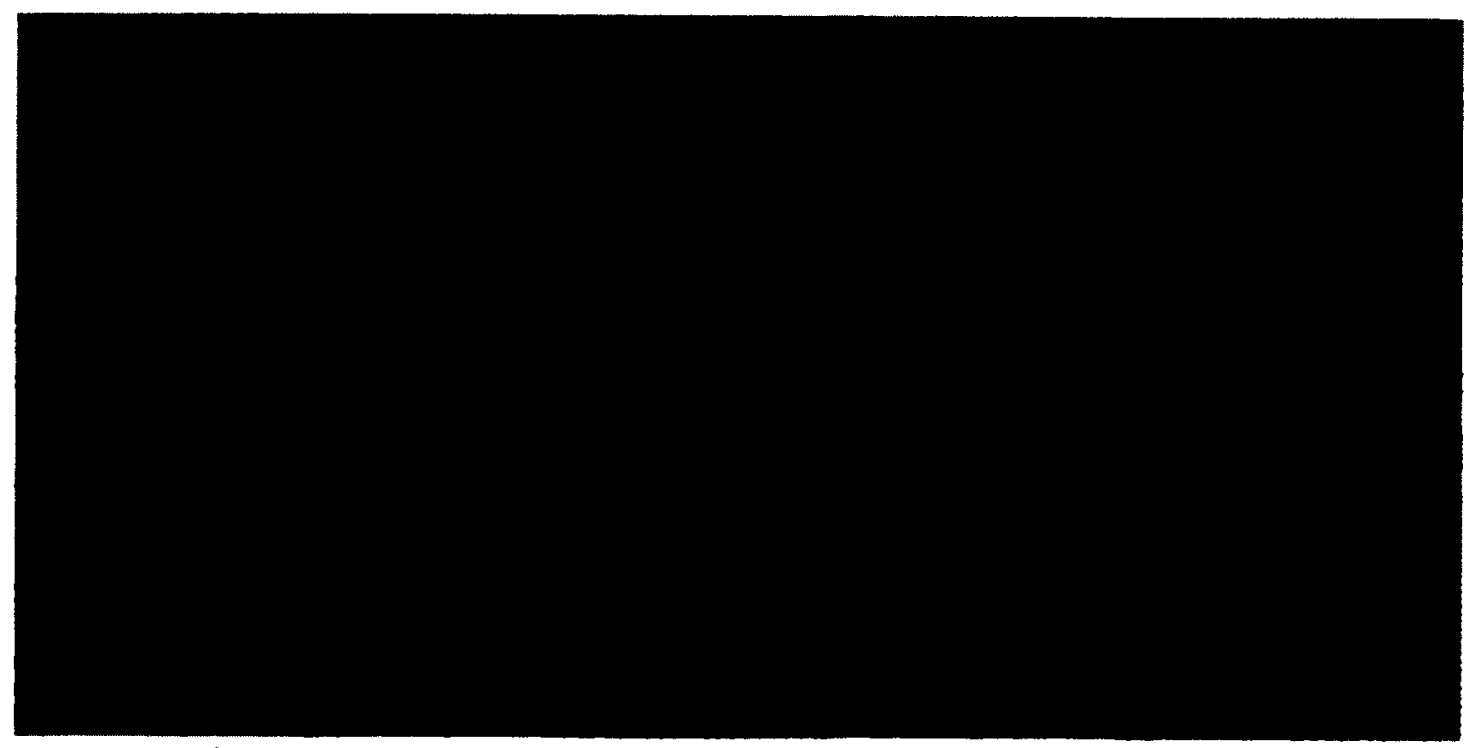

Figure - 15 / Lofting the curves of the letters forming the name Bezalel, using the site plan. 


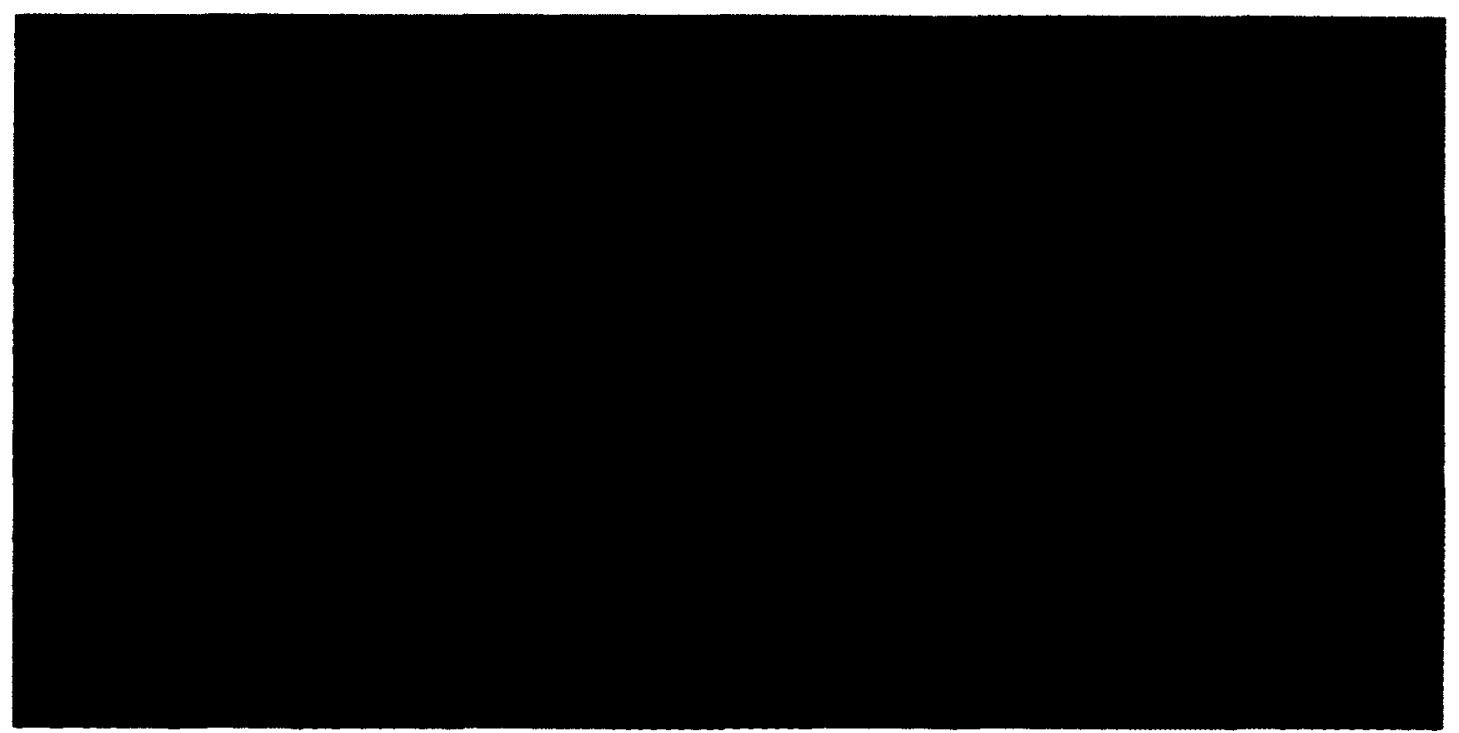

Figure - 16 / Lofting the curves of the letters forming the name Bezalel, using the site plan. 


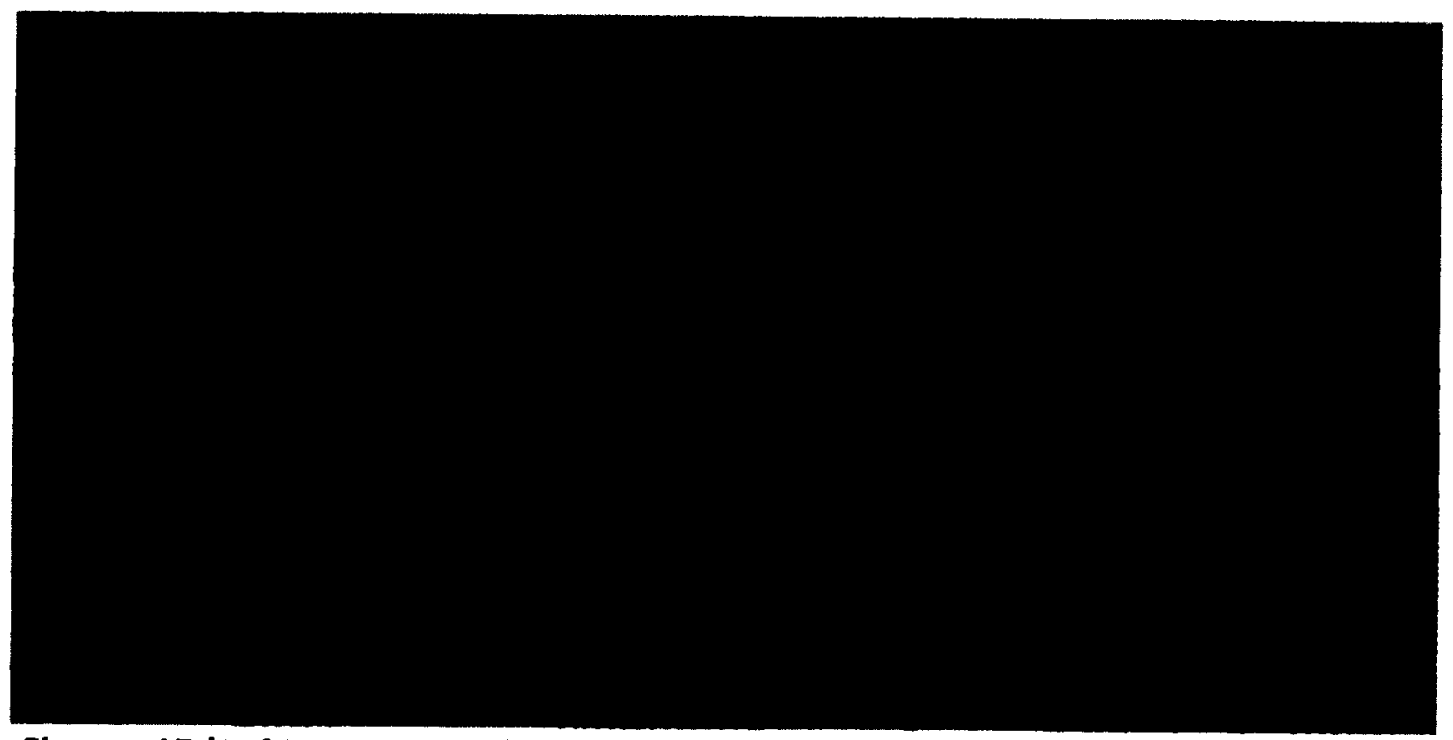

Figure - 17 / Lofting curves with unequal number of verteces. 


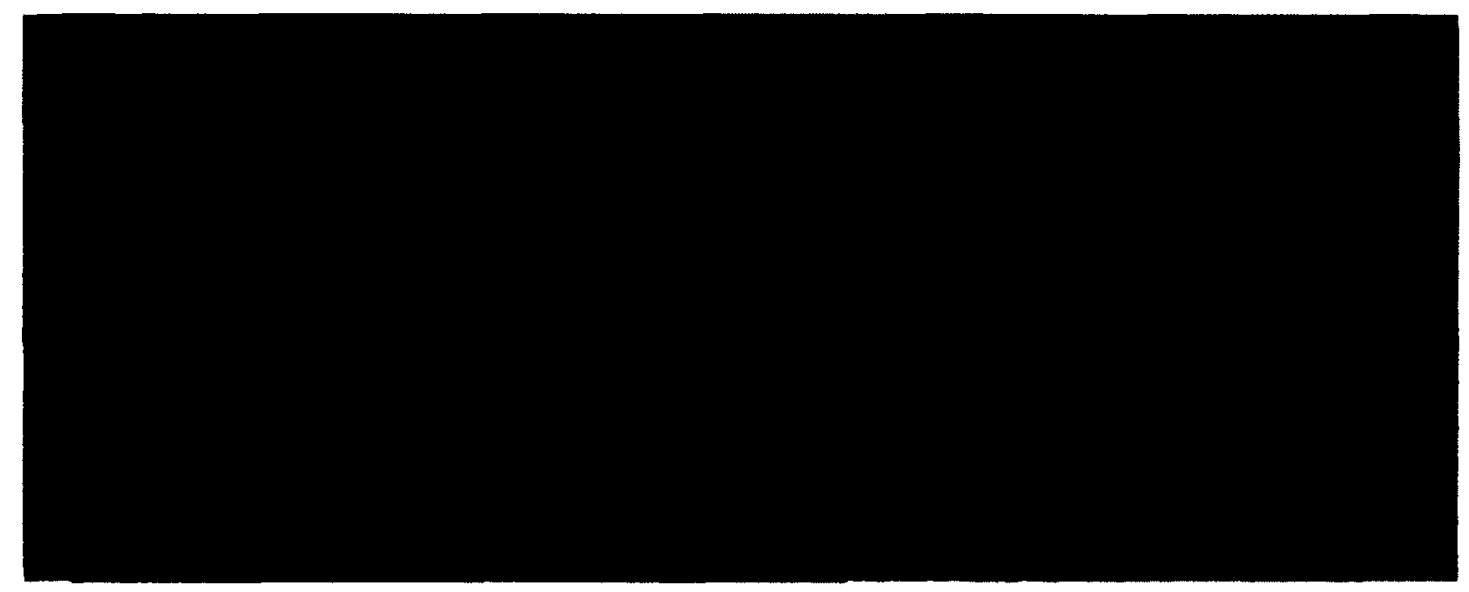

Figure - 18 / Lofting curves with equal number of verteces.

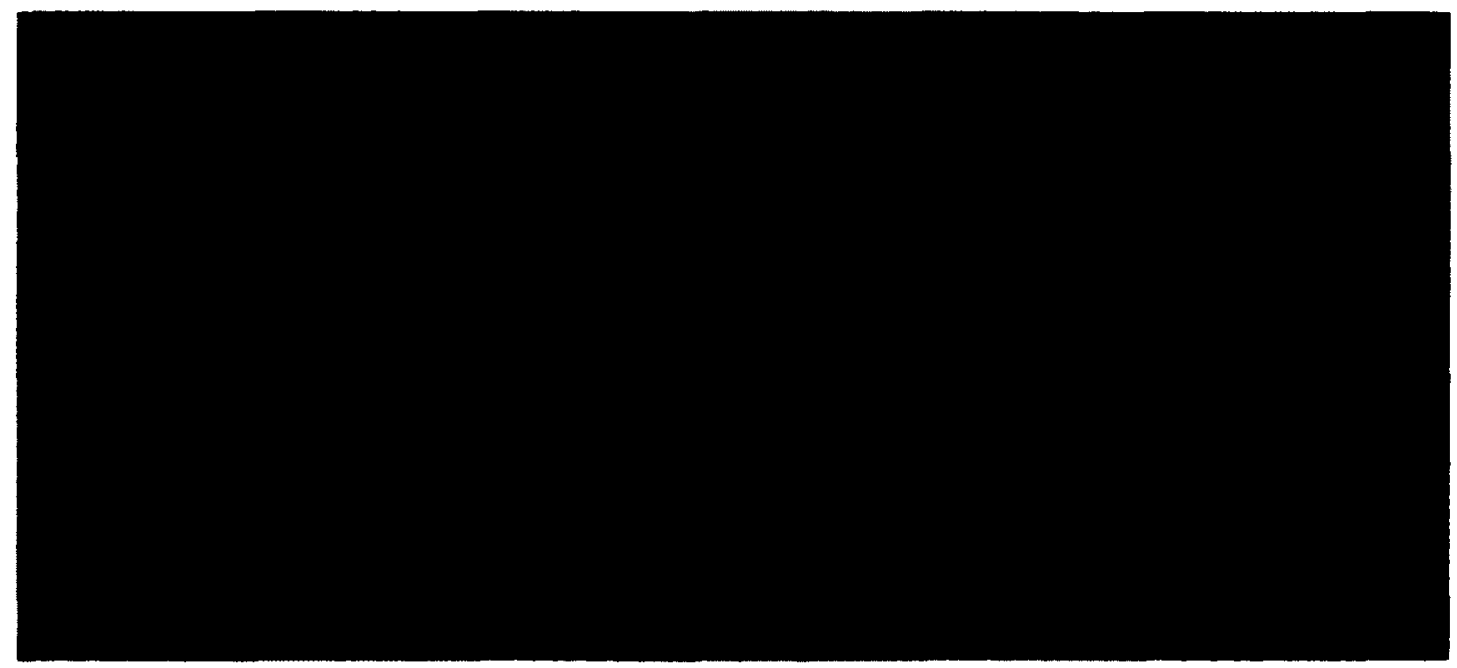

Figure - 19 / Lofting curves with equal number of verteces. 


\section{ii. Geometry Of The 231 Gates}

The Talmud descibes Bezalel's ability to design and build as a method of combining and rearranging Hebrew letters.

"Bezalel knew how to combine the letters with which heaven and earth were created. For it is written (Exodus 31:3) I have filled him with a Godly spirit, with wisdom, understanding, and knowledge. ${ }^{26}$

Perhaps these concepts of design can be abstracted making contemporary geometries of symbolic value. Conceivably by considering the design tool set utilized by God's master builder, Bezalel, formal gestures can be created related to these concepts. It would also seem that in order to examine the Halachic design abilities of the letters, a consideration should be made related to the theory in Jewish tradition associated with using the letters as tools of creation.

Rabbi Michael Munk, descibes the alphabet as containing a "divine science" where certain tools can be used to translate God's will into reality. Munk illustrates and describes these tools as a series of equations. In Munk's book, entitled "The Wisdom in the Hebrew Alphabet", the Rabbi writes of the Sepher Yetzirah as one of these tools of divine science:

\footnotetext{
${ }^{26}$ Scherman, Rabbi Nosson. Schottenstein Edition of the Talmud - Berachos volume 2 (folios 30b64a). Brooklyn, NY: Mesorah Artscroll Publications, LTD. Berachos 55a
} 
"The twenty-two sacred letters are profound, primal spiritual forces. They are, in effect the raw material of Creation. When God combined them into words, phrases, commands, they brought about Creation, translating His will into reality, as it were. There is a Divine science in the Hebrew alphabet. Sefer Yetzirah ['The Book of Creation'], the early Kabbalistic...describes how the sacred letters were used as the agency of creation. ${ }^{27}$

Munk points to the Sepher Yetzirah as illustrating a number of the methods in which the letters can be combined, interchanged, and rearranged producing cosmic spiritual forces[see figure: 20]. By selecting an equation/illustration which encompasses all of the alphabet from Sepher Yetzirah, the exercise remains flexible in numerous contexts. In the second chapter of the book, the idea of time is described in cycles (cycles of years, seasons, months, weeks, days). In Section four of the second chapter, these concepts of time are further abstracted by their combination with the geometry of the cycle (a circle) and the alphabet.

"Twenty-two Foundation Letters:

He placed them in a circle like a wall with 231 Gates.

, 28

\footnotetext{
${ }^{27}$ Munk, Rabbi Michael L. עולם האותית - The Wisdom In The Hebrew Alphabet. Brooklyn, NY: Mesorah Publications, LTD. 2011, pg.19

${ }^{28}$ Kaplan, Aryeh. Sefer Yetzirah The Book of Creation San Francisco, CA: Red Wheel/Weiser, LLC, 1997, pg.108
} 
By positioning the Hebrew alphabet, composed of twenty-two letters, at an even spacing surrounding a circle and drawing connections between each of the letters, a diagram is created/see figure: 21]. This diagram describes all the possible connections between each of the twenty-two Hebrew letters. Sepher Yetzirah expresses the most basic combination of the twenty-two letters by writing of the "231 Gates". The diagram, being a circle, allows an expression of the letter connections by mathematical formula, where " $L "$ is made the value of all connections and " $n$ " is made the number of points:

$$
\begin{aligned}
\mathrm{L} & =n(n-1) / 2 \\
& =22(22-1) / 2 \\
& =231
\end{aligned}
$$

[See Sepher Yetzirah (chapiters 1:13 \& 2:4) for further theoretical analysis related to the Judaic theories behind the concept of the "231 Gates".]

For the purposes of architectural experimentation, the 231 gate alphabet circle diagram can be used to generate two dimensional geometries based on any Hebrew name or combination of Hebrew letters. In the following chapters a geometry using this technique will be proposed with both the Judaic theory related to Bezalel, the Biblical character, and the geometry's measured application with the design for Bezalel, the Academy of Art and Design. 

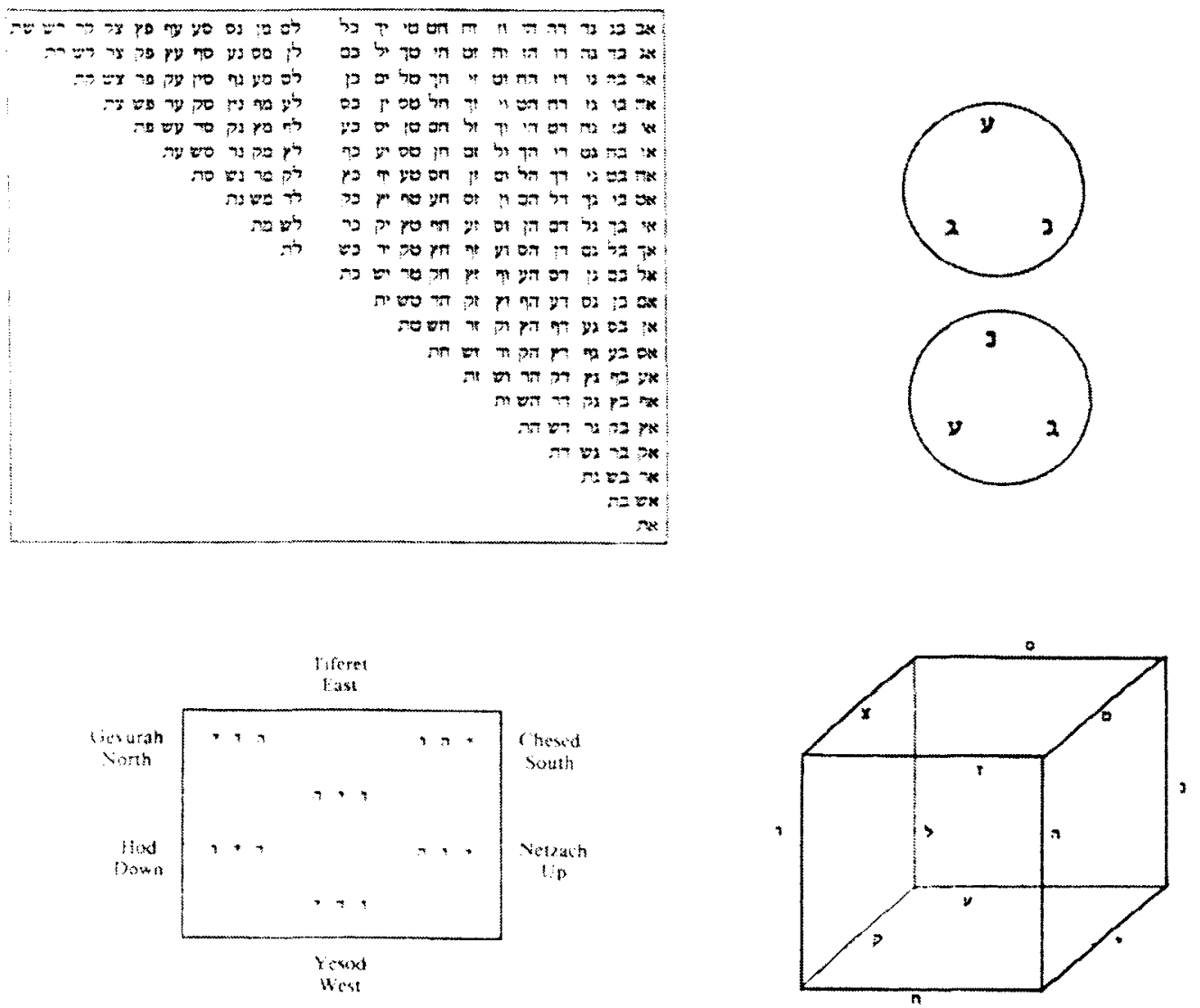

Figure - 20 / Diagrams expressing Hebrew letter Kabalistic relationships. Source: Kaplan, Aryeh. Sefer Yetzirah The Book of Creation San Francisco, CA: Red Wheel/Weiser, LLC, 1997 


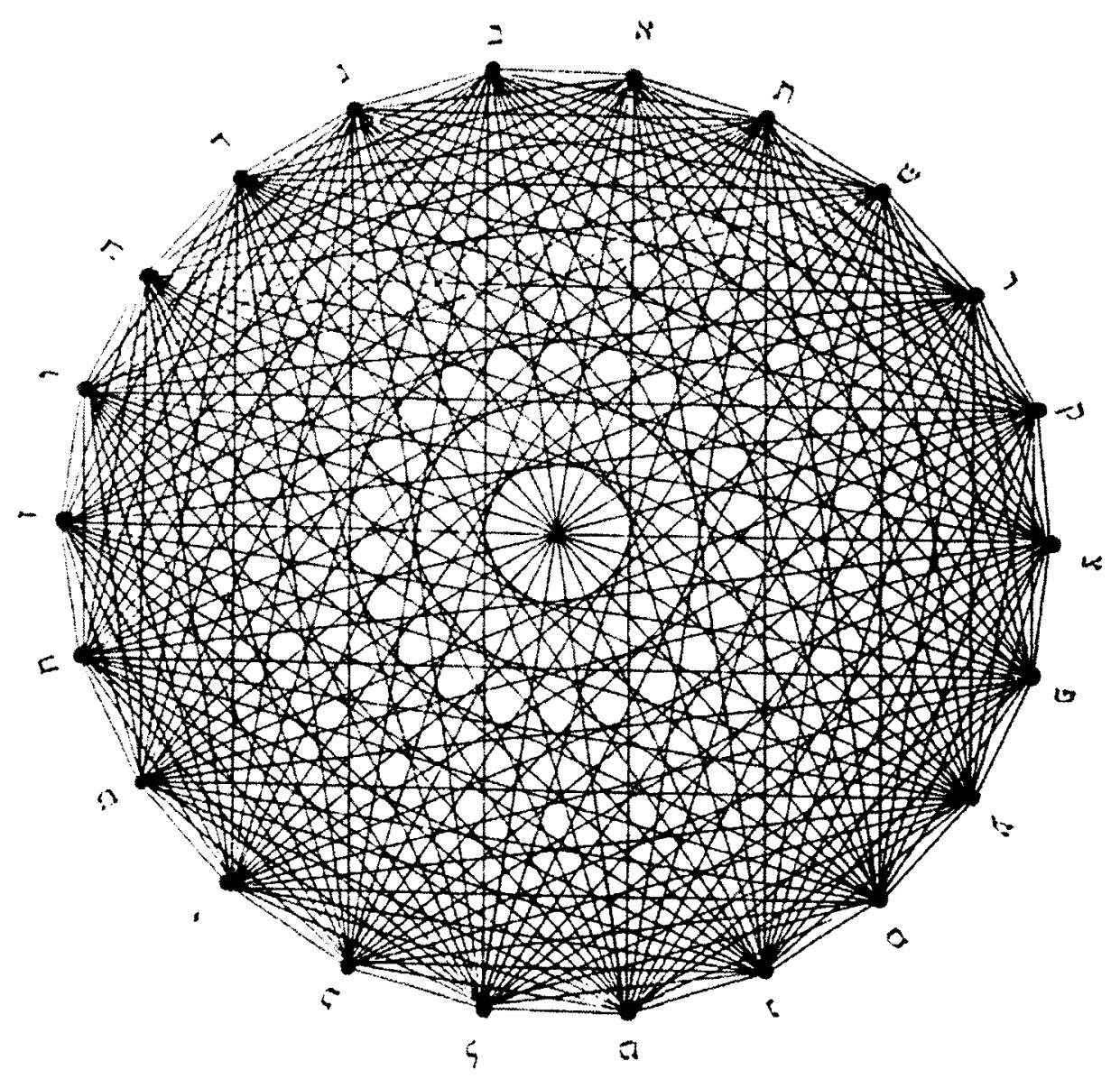

Figure - 21 /Hebrew letter Diagram expressing the 231 Gates. Source:

Kaplan, Aryeh. Sefer Yetzirah The Book of Creation San Francisco, CA: Red Wheel/Weiser, LLC, 1997 


\section{iii. Spacing By Cantorial Notation}

Traditionally, when the Torah is recited at the synagogue, there is a notation system entitled: טעמי המקרא (Ta-amey HaMikrah - Taste [or sense] of the Scripture). The two predominant purposes of the notation relates to a necessity in providing emphasis for the phrasing and the recollection benefits in adding melody to what is sung. The notation system illustrates the melodic differences by means of a variety of symbols. Emphasis is indicated by the position of the symbol in context to the letter within the word. [see figure: 22]

"the signs are also called n'ginot (melodies)...they are never copied in the scrolls that are used for the liturgical reading in the synagogue...the reader is obligated to memorize the signs in order to effect a correct cantillation. ${ }^{129}$

These n'ginot are architecturally interesting considering the method of teaching their melodic differences. Where in modern musical notation a dot placed on a staff accompanied by a shaped tail determines the pitch and duration of each note, a Chazzan will teach the n'ginot patterns by a memory sound patterns. As a learning tool some Chazzanim have used visual illustration to aid in describing the shape of the n'ginot [see figure: 23]. The visual illustrations of these notations being of simple lines summarize

\footnotetext{
${ }^{29}$ Portnoy, Marshall and Josee Wolff. The Art of Torah Cantillation New York, NY: Union of American Hebrew Congregations Press, 2000, pgs. 68-69
} 
the general musical form. In accepting that these lines describe the musical shape of the n'ginot, their spacing and proportions can then be scaled to work within an architectural dimension. The preceding chapters will demonstrate a method of applying the musical spacing of Torah notation, associated with the Pashat which introduces Bezalel, the biblical character, to an architectural scale and dimension. Additionally, the results of this method will be configured with the programmatic requirements of Bezalel the Academy. 


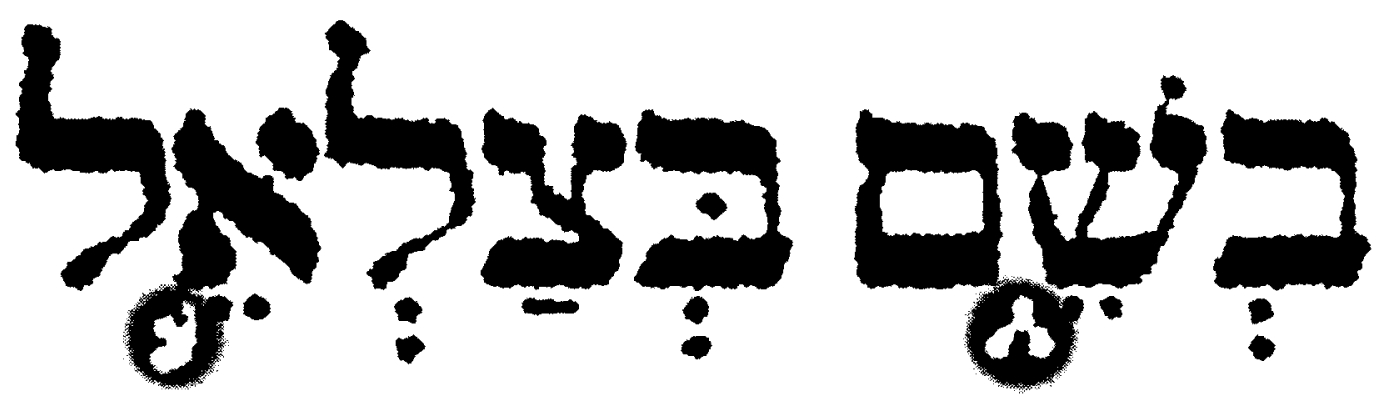

Figure - 22 (Hebrew Words with n'ginot (cantillation notation). Text Image modified by author. Source: Scharstein, Asher Ben David. Tikun La-Kor'im: Kolel Hamsah Humshe Torah Hoboken, NJ: Ktav Publishing House Inc. 1969 
EVANS S-KERT LTD.

IAI KALNOAR AVE

TTAWA, ONT. KIV BS9 MHMO TORAH NOTES

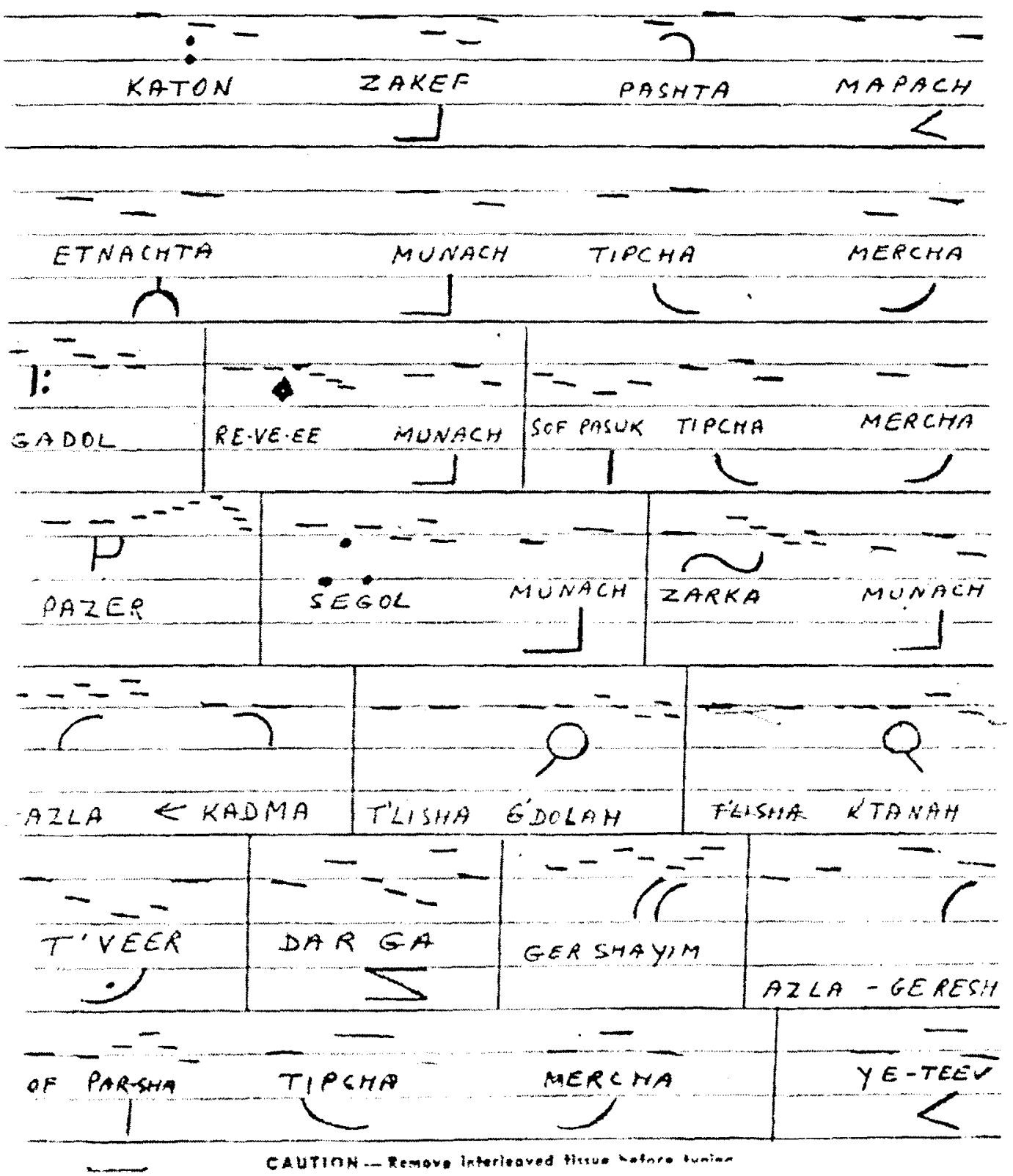

Figure - 23 /lllustrated n'ginot (cantillation notation). Diagram by: Cantor Emeritus David Aptowitzer, Agudath Israel Congregation of Ottawa. 


\section{iv. Inherent Arch Proportions}

Jerusalem holds a strong connection with stone as its primary symbolic building material [see figure: 24], so much so that the specific local stone is commonly referred to as אבן ירושלמית (Jerusalem Stone). The pale limestone is a prominent cultural symbol for the city, often being used in Jewish art pieces, menorahs, seder plates, paintings, sculpture, and song among other examples. Due to a dominant use of stone, the arch plays a prominent role within the palette of the city's architectural language, especially within the Old City[see figures: 25, 26, 27]. As an exercise in the design of a geometry derived using Judaic symbols, the arch, with its connection to the architectural language of Jerusalem, was selected as a building geometry that could be modified in a way where the proportions of the arch would be inherently related to the proportions of specific symbols. The Arch, in its design infancy, is credited in evolving from Greco Roman geometrical thought, where figures such as Plato and Vitruvius developed dimensional relationships as building design tools. The Neufert publication on Architectural Data gives a basic description on the progression of these dimensional relationships. 
"The geometric shapes named by Plato and Vitruvius...(i.e. circle, triangle and square from which polygonal traverses can be constructed). The respective bisection then results in further polygonal traverse."

[see figure: 28 ]

These polygon traverses were specifically important to 'round' design, where a round element is abstracted by its division into a series equal linear segments having points along the curve of the round geometry/see figure: 29]. This generating of polygonal traverses from a mathematical abstraction of basic geometric forms becomes a tool for generating more complex geometries.

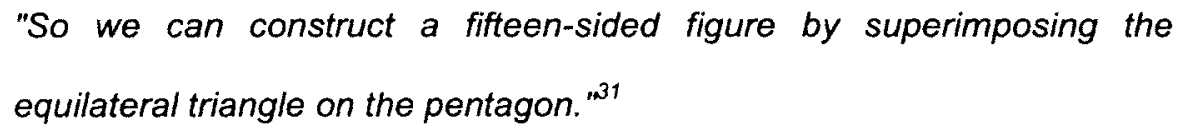

By means of these exercises the Greco Roman thinkers (believing in the purity of the basic forms) were able to create designs having inherent geometries latent within their composition, for example by aligning the points of a triangle within the circumference of a circle, proportional relationships could be measured.

\footnotetext{
${ }^{30}$ Neufert, Ernst \& Peter Neufert, Bousmaha Baiche \& Nicholas Walliman Neufert Architects' Data, Third Edition Oxford, UK: Blackwell Science Ltd., 2000, pg. 27

${ }^{31}$ Neufert, Ernst \& Peter Neufert, Bousmaha Baiche \& Nicholas Walliman Neufert Architects' Data, Third Edition Oxford, UK: Blackwell Science Ltd., 2000, pg. 27
} 
The development of arch types, from these fundamental concepts, evolved to contain a series of arches derived from points, lines, angles, and abstracted shapes. For example: the segmented arch, the four centered arch, the five centered arch, the gothic arch, the equilateral four pointed arch [see figure: 30]. These arch methods contain possibilities for modification where the inherent shapes used in their geometrical design include symbolism as forms abstracted in determining their dimensions.

For this design intervention, the geometry of the "Seal of Solomon" was selected due to its relationship with the site for the new Bezalel Academy, and in having a cultural allegory associated with King Solomon, who is said to have established the city as one of peace and justice. The Allegory mentions King Solomon as being given a ring from God, composed of a geometry generally recognized as a hexagram made up of two layered equilateral triangles placed within a circle while the name of God is engraved in the centre[see figure: 31]. The parable mentions that with the seal, the King possessed magical powers. From Islamic literary culture the series of short stories entitled 'One Thousand and One Nights (or Arabian Nights Entertainments)' describes King Solomon's ability in being able to capture evil demons (djinn) with the power of the seal. The Allegory suggests that these demons were obstructing the successful completion of The Temple: 
"In one of the 'Arabian Nights Entertainments', an evil djinn is described as being imprisoned in a copper bottle for 1,800 years by a lead seal stamped by the ring. Other later books ('Pseudomonarchia Daemonum') manage to fit far more demons in the bottle. ${ }^{, 32}$

The Kabbalistic literature also indicates powers contained in the symbol of the "Seal of Solomon". These powers enable(d) visions of God, and as a result one gains significant wisdom and knowledge [see figure: 32 ]. The 790 רזיאל המלאך(The Book of Raziel the Angel), controversially credited as the first book of Kabbalah (having been given to Adam and Eve), illustrates the "Seal of Solomon" as a part of the symbolic language of the Angels known as oxigils). The Kabbalistic conception of the seal extends to include descriptions of symbolic qualities related to a combination of opposites:

"...King Solomon's Seal, whose base is on the ground and whose tip reaches heaven, symbolizes a harmony of opposites, whose significance is manifold as much as it is multi-cultural...is common to Judaism, to Christianity and to Islam. It reflects the cosmic order, the skies, the movement of the stars in their spheres, and the perpetual flow between heaven and earth ${ }^{133}$

\footnotetext{
${ }^{32}$ Wikipedia - The Free Encyclopedia Seal of Solomon Interntet: http://en.wikipedia.org/wiki/Seal_of_Solomon, July 16, 2012 [August 5, 2012]

${ }^{33}$ Weill, Asher [Editor] King Solomon's Seal A selection from The Israel Review of Arts and Letters 1998/vol 106 Internet:

http://www.mfa.gov.il/MFA/MFAArchive/1990_1999/1999/2/King_Solomon-s_Seal, Februay 16, 1999 [August 05,2012]
} 
Sultan Suleiman, who was in control of Jerusalem during the 16th Century restored many aspects of the Old City including the Temple mount. It is thought that he likened himself to King Solomon, such that the renovations included خاتم سليمان (Seals of Solomon).

"...Sultan Suleiman the Magnificent ordered extensive restorations... On the walls which he built around Jerusalem, are stone decorations in the form of two interlocking triangles (Stars of David), known to Muslims as Khatam Suleiman and to Jews as Khatam Shlomo (Kin Solomon's Seal) whose function was to protect the city. ${ }^{\text {, } 34}$

The grouping of the religious, cultural, and somewhat mystical meanings behind the seal, makes for an interesting symbol to consider as an exercise in proposing an architectural intervention based on the Seal's proportions. The exercise begins by drawing a basic three point arch above a conventional institutional double doorway ( $7^{\prime}$ height $\times 7^{\prime}$ width). The three point arch is first drawn by determining the radius of the arch in measuring the centre line of the doorway. With the centre line as the divider, the midpoints are determined for each of the upper most segments of the doorway. Drawing a circle on each of the determined midpoints, one uses the distance from the determined midpoints to the

\footnotetext{
${ }^{34}$ Weill, Asher [Editor] King Solomon's Seal A selection from The Israel Review of Arts and Letters 1998/vol 106 Internet:

http://www.mfa.gov.il/MFA/MFAArchive/1990_1999/1999/2/King_Solomon-s_Seal, Februay 16, 1999 [August 05,2012]
} 
upper corners of the opening. To draw the curve that completes the arch by joining the curves of the two circles: a centre line is drawn at a right angle to the ground plane, the center point of the opening on the right angled centreline is then established. Two lines are drawn by connecting the two midpoints (determined earlier) with the center point. The radius of the final curve is determined by the location at which the lines intersect the upper portion of each circle [see figure: 33].

To combine the principles of drawing a three point arch and using the "Seal of Solomon" as a proportional guideline: 1-Draw a conventional institutional doorway. 2-Align the centre point of the seal with the midpoint of the upper segment defining the required opening. 3-Extend the upper segment horizontally to double the length. 4-Draw a line from the bottom small triangle (where it meets the circle) at an angle so that it should intersect the point of the adjacent triangle where it also intersects the circle. 5-Extend the line until it intersects with the upper segment. 6Repeat steps 4 \& 5 for the opposite side. 7- Draw a three point curve using the points from the intersected upper segment and the point of the upper most triangle where it meets the circle. 8- Where the upper segment intersects the Seal, draw a line from the point shared by two triangles on either side of the upper left side of the segment to the point of the upper left triangle intersecting the circle. 9- Extend the last drawn line to the curve, and use this length to draw a circle also using the point 
shared by two triangles on the upper segment as the centre point. 10Repeat Steps 8 \& 9 on the opposite side 11- Draw a small circle using the midpoint of the lowest segment in the upper most triangle, and using the points meeting its adjacent triangles to determine the diameter. 12Complete the arch by drawing the second lower three point curve by using the upper centre quadrant of the small circle and the two upper corners of the opening [see figure: 33]. 


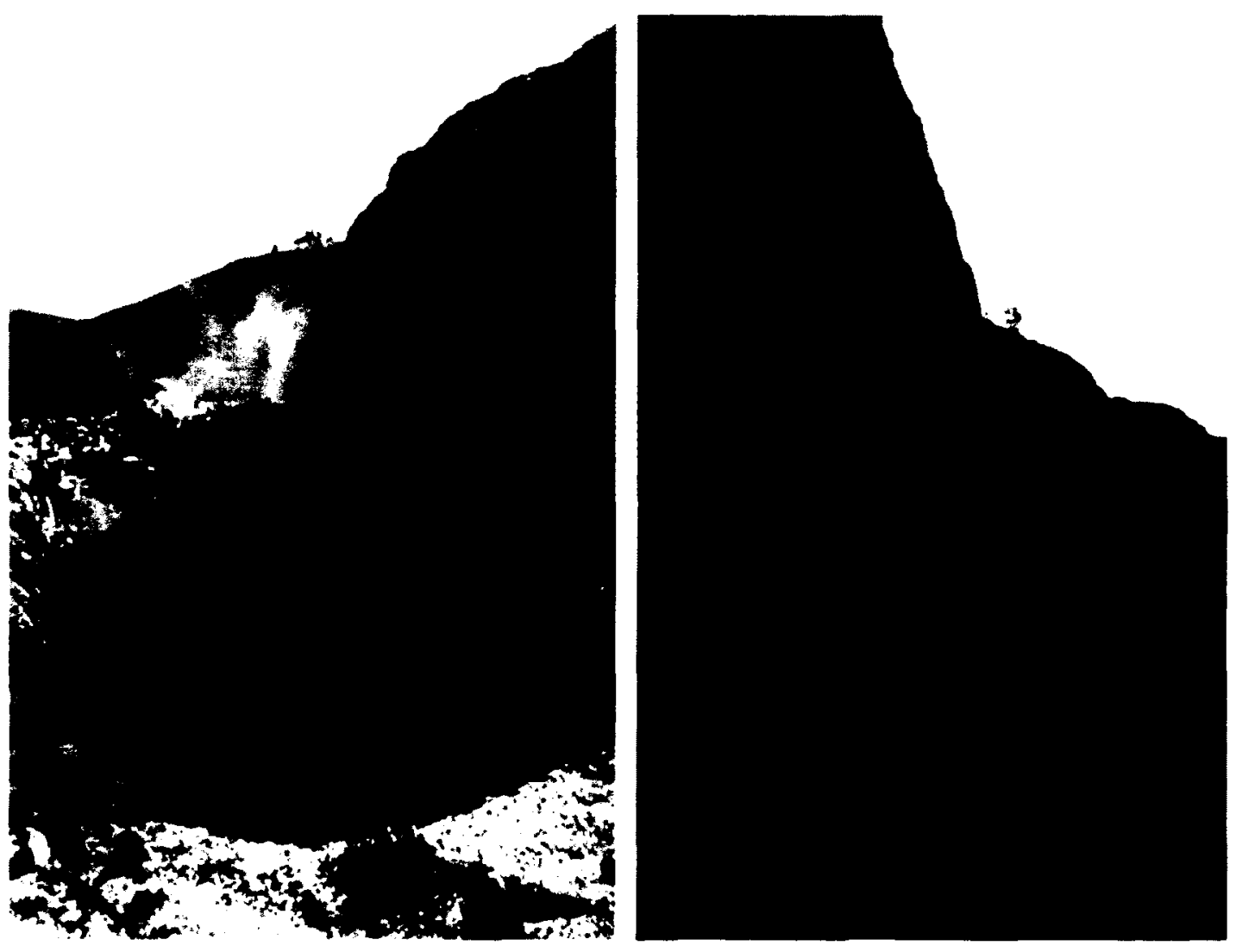

Figure - 24 /Local Jerusalem Stone Quarry. Image by the Author. 


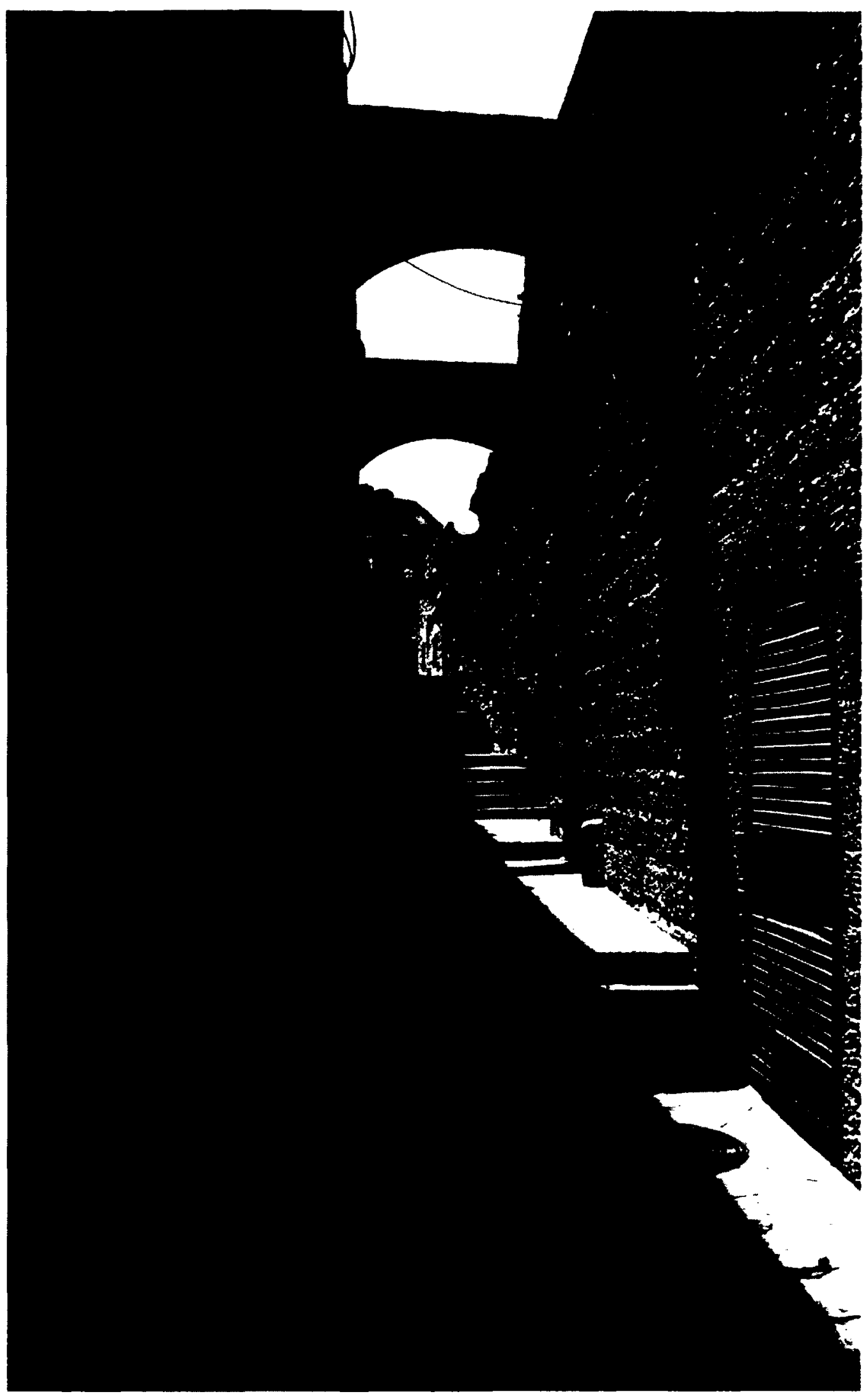

Figure - 25 /Old City Jerusalem street - scape.

Source: http://www.flickr.com/photos/alexsven/7472623126/in/pool-jerusalem 


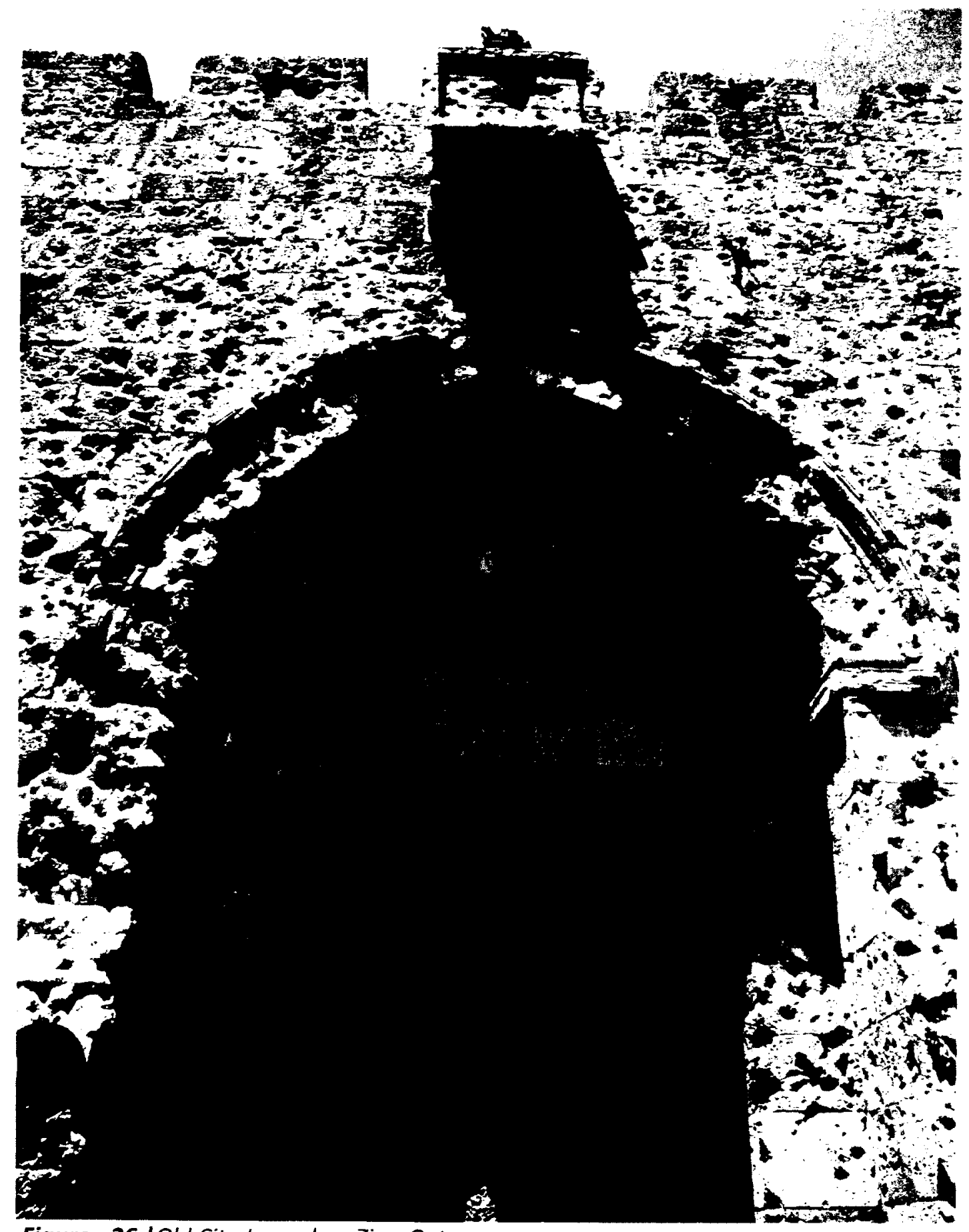

Figure - 26 /Old City Jerusalem Zion Gate.

Source: http://www.flickr.com/photos/alexsven/7472617372/in/pool-jerusalem 


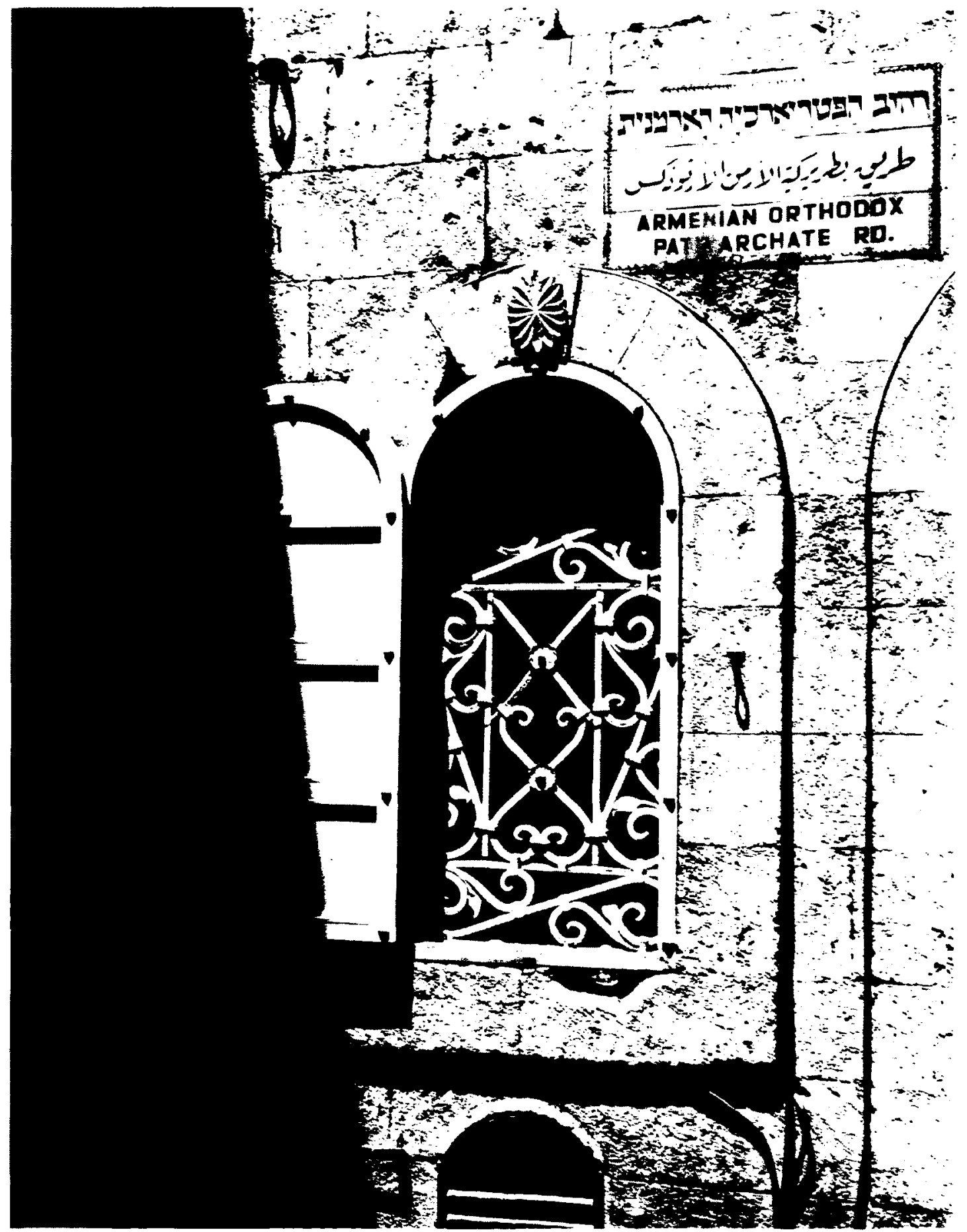

Figure - 27 /Old City Jerusalem Armenian Quarter Window detail.

Source: $h$ ttp://www.flickr.com/photos/thelastdon/7622242392/in/pool-jerusalem 

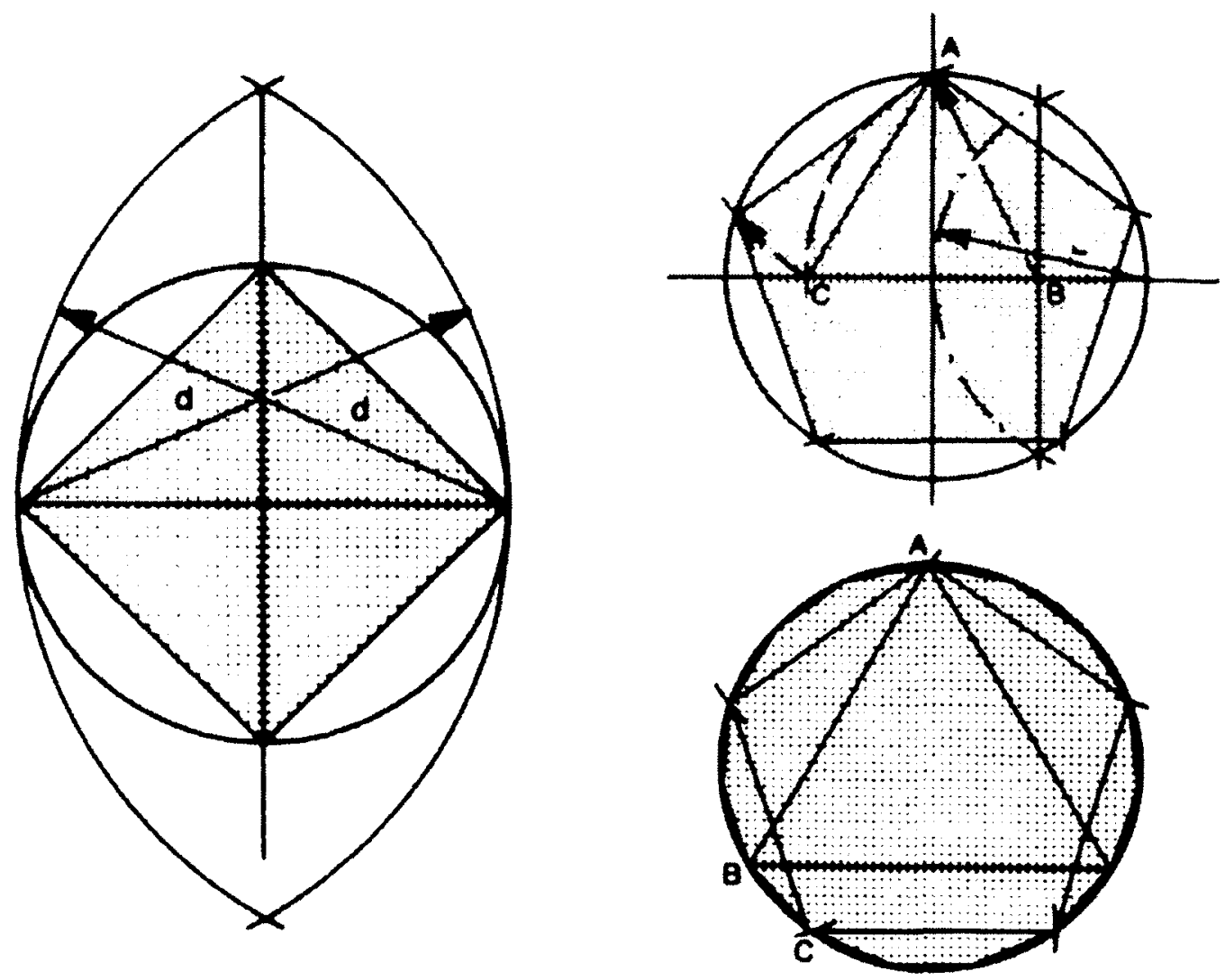

Figure - 28 / Calculating polygonal traverses using basic geometrical shapes. Source: Neufert, Ernst \& Peter Neufert, Bousmaha Baiche \& Nicholas Walliman Neufert Architects' Data, Third Edition Oxford, UK: Blackwell Science Ltd., 2000 


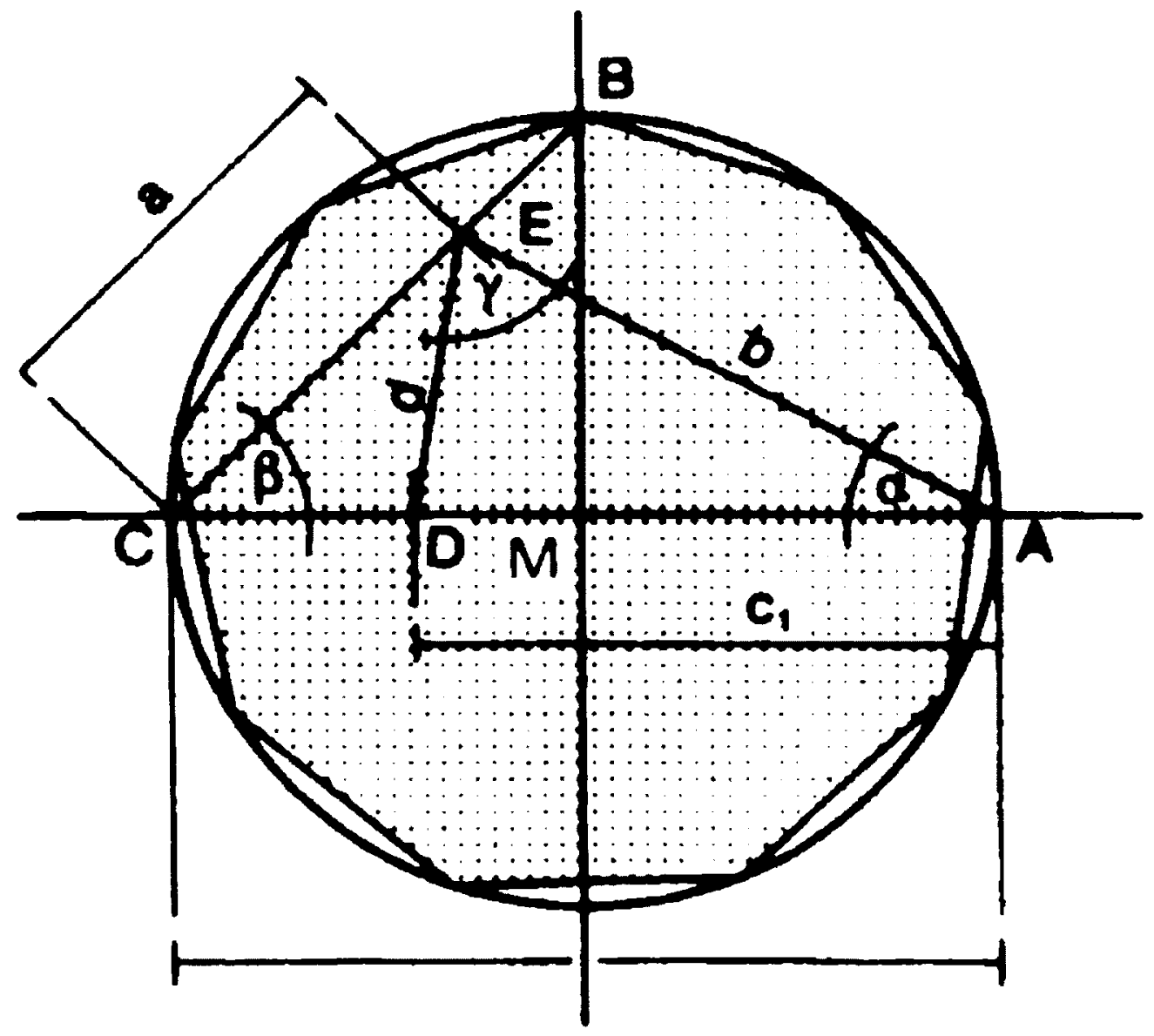

Figure - 29 | Polygon traverses used in creating round linear design.

Source: Neufert, Ernst \& Peter Neufert, Bousmaha Baiche \& Nicholas Walliman

Neufert Architects' Data, Third Edition Oxford, UK: Blackwell Science Ltd., 2000 


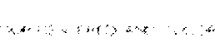

Figure - $\mathbf{3 0}$ / Graphic Standards Arch examples.

Source: Ramsey, Charles George \& Harold Reeve Sleeper \& John Ray Hoke Jr. Architectural Graphic Standards CD-ROM V3.0

New York, NY: John Wiley \& Sons Inc., 2000 


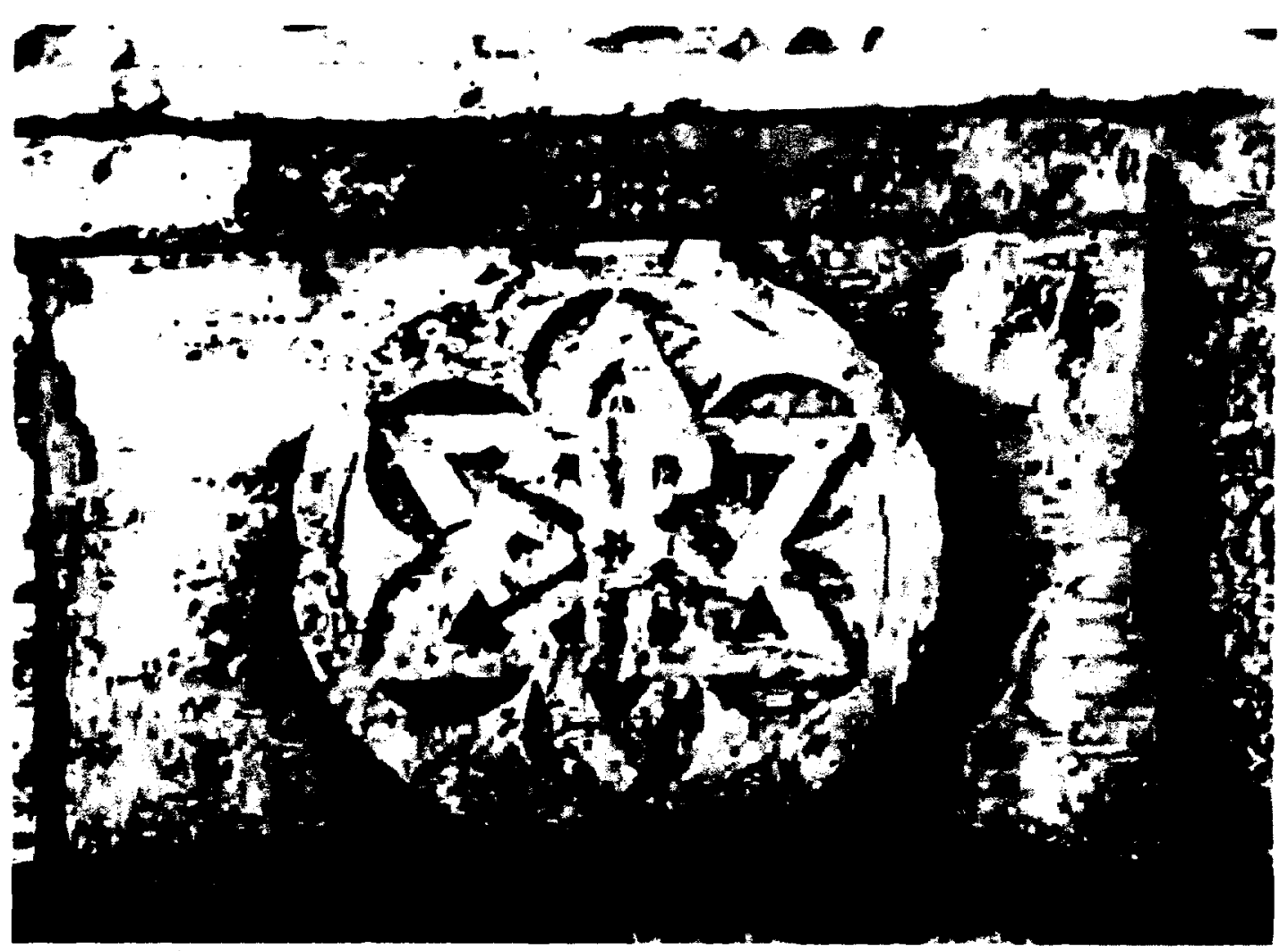

Figure - 31 / The Seal of Solomon at Lions Gate, Old City Jerusalem.

Source: http://star-of-david.blogspot.co.il/2010 0831 archive.html 
Txm רטי

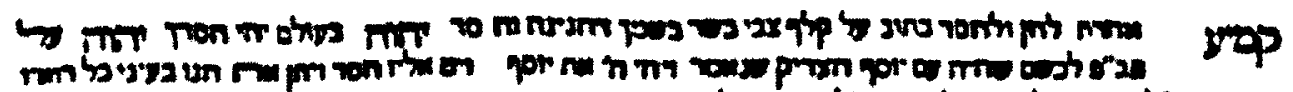

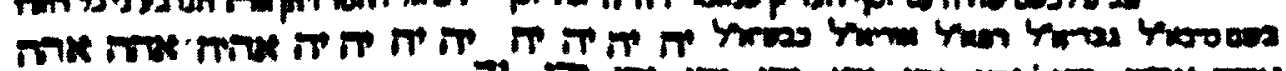
0.

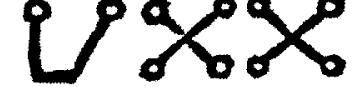

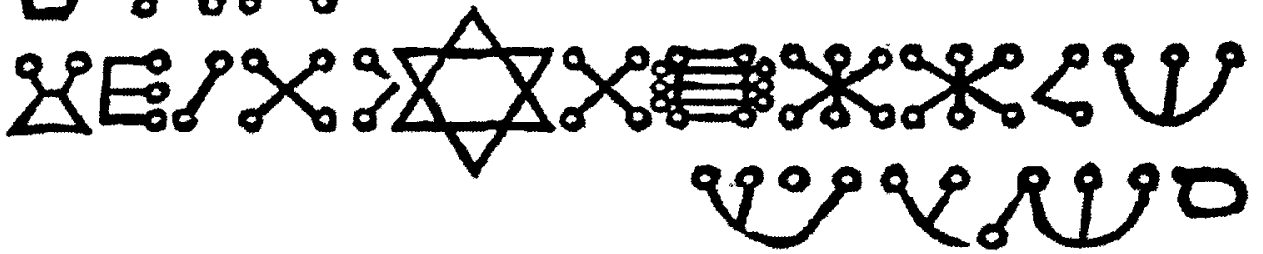

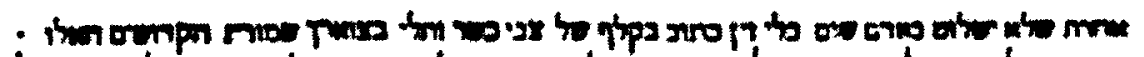

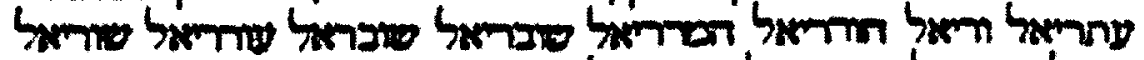
oroo orpa pom pank

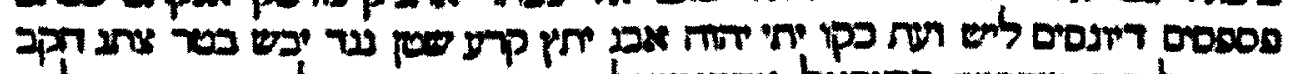
Whe o

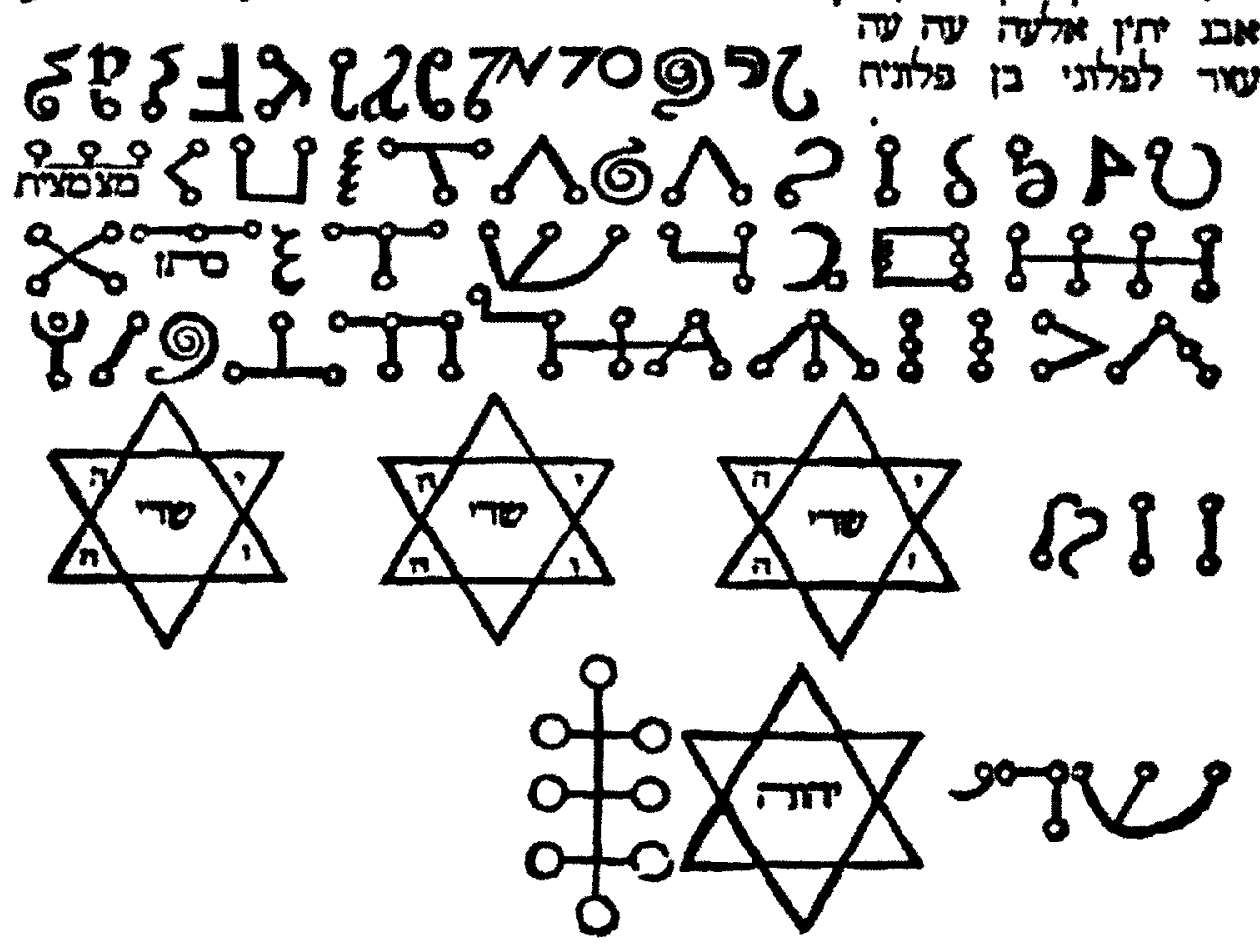

Figure - 32 / סגולות (sigils) - Angelic script including the Seal of Solomon.

Source: Savedow, Steve. Sepher Rezial Hemelach: The Book of the Anqel Rezial

Kindle Edition, York Beach, ME: Samuel Weiser Inc., 2010

(Kindle Location-6537) 

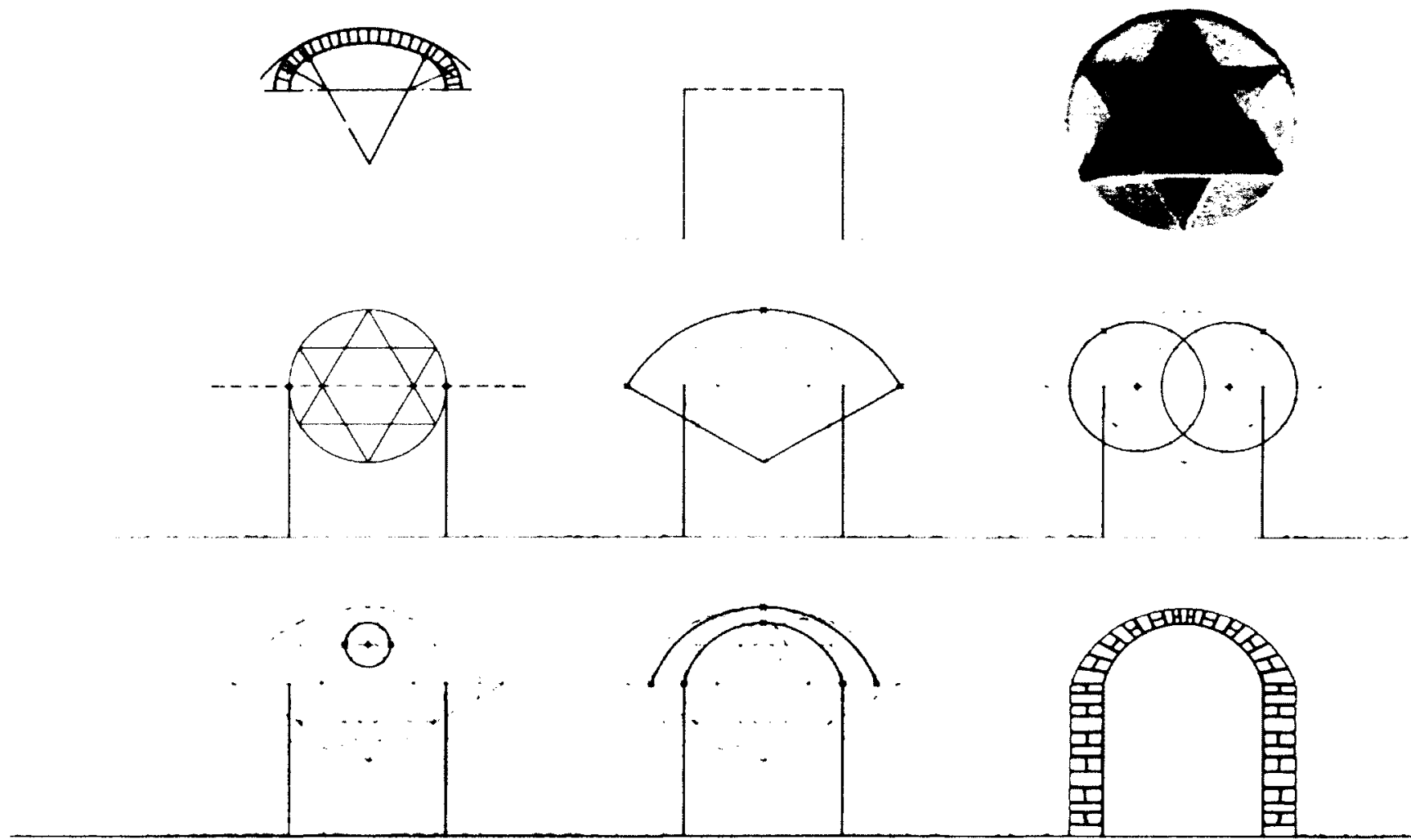

Figure - 33 / Three Point Arch and Six Point Arch influenced by the Seal of Solomon. Illustration by the author. 


\section{v. Light Through The Proportions Of The Letters}

When a word or a name is mentioned in the Torah for the first time, it signifies a deeper meaning of the term than on other occasions. This initial mentioning in the Torah could also have relationships with the contextual allegory associated with the naming of that thing, place, or person. For example: the Israelites are called a Nation (עם - Am) initially in "Paraha Shmot" ("Chapter Names", the first chapter in the book of Exodus) by Pharoah who plans to enslave them, in order to take advantage of their laborious contributions to the country yet as an attempt to resolve his sentiment of being culturally threatened by a potential population majority in Egypt. The Babylonian Talmud interprets this preliminary writing of the word Nation as having a deeper relationship with anti-Semitism:

"The Egyptians were frightened by the growth of Israel. The Jews were becoming too numerous, too strong. They might overwhelm the natives but they are too useful to be permitted to leave the country. It was the first instance in history of what has become the familiar pattern of antiSemitism ${ }^{\text {35 }}$

By considering this theory of the first mentioning in the Torah as having a more profound meaning, this suggests that the first Parshot in which Bezalel is mentioned is of a greater nature than those that follow. One could also propose

\footnotetext{
${ }^{35}$ Scherman, Rabbi Nosson. The Chumash (the artscroll series / Stone edition) - The Torah: Haftoros and five Megillos with a commentary anthologized from rabbinic writngs Edited by Rabbi Hersh Goldwurm, Rabbi Avie Gold, and Rabbi Meir Zlotowitz. Brooklyn, NY: Mesorah Publications Ltd, 1993, pg.293
} 
that the physical contours of the letters have additional significance. When considering the importance of the inscription of the Hebrew Letters, and their rigorous specifications delegated to a Sopher (The profession of inscribing Torah Scrolls), it is noted that these Hebrew Letter specifications are diverse and complex: no letter may be added, no letter may be deleted, all the tools of the scribe must conform to strict specifications, pronouncing every word aloud while inscribing the words on parchment, etc. The attention to detail suggests a work containing celebrated qualities. Architecturally, what seemed most interesting regarding this list of requirements came from those related to the proportion of the letters:

"-If a single letter was so marred that it cannot be read at all, or resembles another letter (whether the defect is in the writing, or is due to a hole, tear or smudge), this invalidates the entire scroll. Each letter must be sufficiently legible so that even an ordinary schoolchild would distinguish it from other similar letters.

-The scribe must put precise space between words, so that one word will not look like two words, or two words look like one word. ${ }^{366}$

The writing of "Mishnat Sofrim", the authoritative work on this subject, describes these important details in considering the spacing in between the letters just as important as the proportion of the letters themselves.

\footnotetext{
${ }^{36}$ Aish HaTorah's Discovery Seminar. The great success of Jewish tradition is the meticulous transmission of the Torah text. But actually how accurate is it? Internet: http://www.aish.com/h/sh/tat/48969731.html, May 14, 2002 [July 27, 2012]
} 
Jewish Kabbalists read the Hebrew letters as symbols of a dynamic processes which is a part of an esoteric structure, where the formation of the world is enacted through certain combinations of the letters of the Hebrew language. It is thought that by means of this method of understanding, the entire Torah isn't just a series of letters, words, and allegories but rather a unified and complete Name for God.

Kabbalist and contemporary Jewish Scholar, Rav Berg, describes his understanding of אור חזר (Returning Light), as related to Hebrew letters having intrinsic "intelligent energies". Berg describes the letters as being tools of creation, containing cosmic energies, and in order to re-invigorate the cosmic flow one must learn to reject the energy by giving energy:

"The rejection of energy creates the intelligence referred to in Kabbalah as Or Chozer (Returning Light). This newborn intelligence takes the place of the negative pole and acts as a Vessel. Paradoxically, an intelligence created for the purpose of rejecting the Light now assumes the role of receiving the Light... this new intelligent life-form (Returning Light) allows ... the flow of cosmic energy to be reestablished". ${ }^{37}$

If the letters are the materials which make up our world, perhaps Rav Berg is suggesting that one reaches the light of creation not by consuming these

\footnotetext{
${ }^{37}$ Berg, Rav P.S. The Energy of Hebrew Letters: The Quantum Story of the Original Alphabet Kindle Edition, New York, NY: Kabbalah Centre International, Inc. 2010 pg.80
} 
"energies" but by giving. In other words through the giving of light one is exposed to the light of creation. While Berg may be somewhat poetic and vague relating the letters to a notion of divine light, Gershom Scholem writes that there is an immediate connection between the light and the mystery of the Torah:

"...the light and the mystery of the Torah are one, for the Hebrew word אור ('or), light and the Hebrew word (raz), mystery have the same numerical value, 207. When God said, 'Let there be light,' he meant, as the author of the Midrash Ha Ne'elam puts it, the mystery that shines in the Torah. ${ }^{38}$

Maintaining a design related goal of using the letters as a language dealing with the exterior to the interior light (and vis versa at night), an effort could be made in abstracting these concepts in a way where they point to the hidden qualities and proportions within letters. Having the biblical character of Bezalel, as a central abstracted concept in the design, it seems appropriate to draw from the first Torah Parsha mentioning God's Architect [see figure: 34] as a filter which wraps the contained light at night and shapes the received light during the day.

\footnotetext{
${ }^{38}$ Scholem, Gershom. On The Kabbalah And Its Symbolism New York, NY: Schocken Books Inc. 1965, pg.63
} 
71979

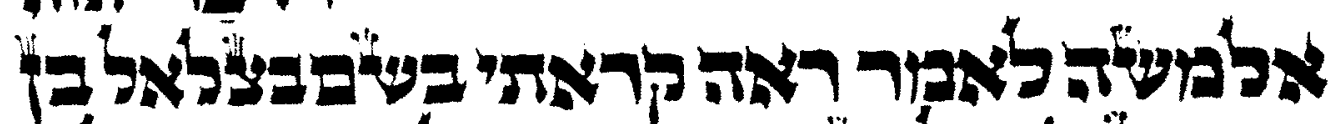

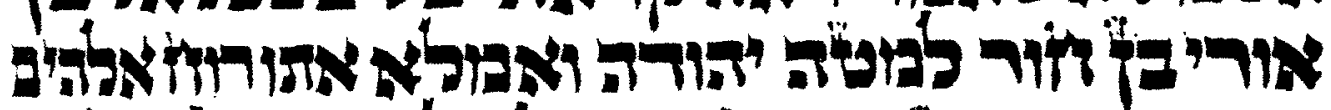

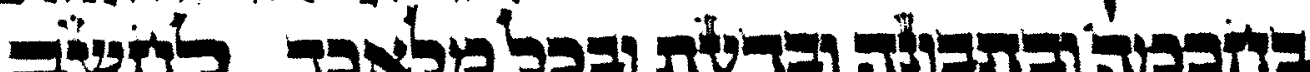

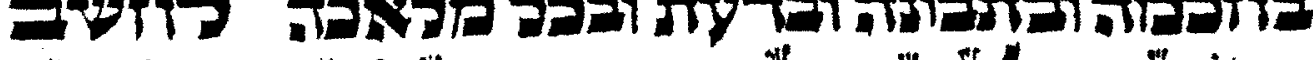

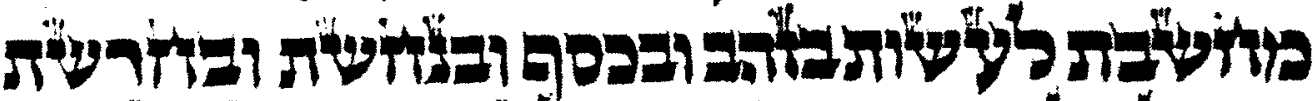

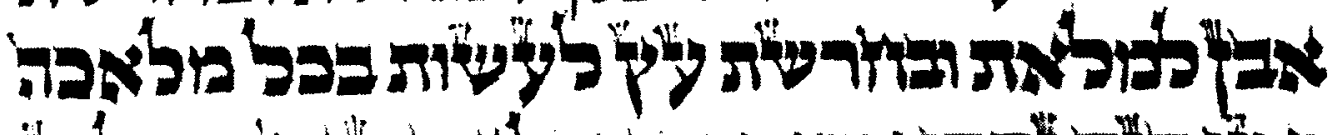

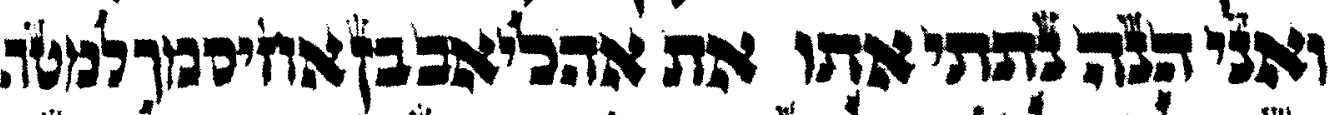

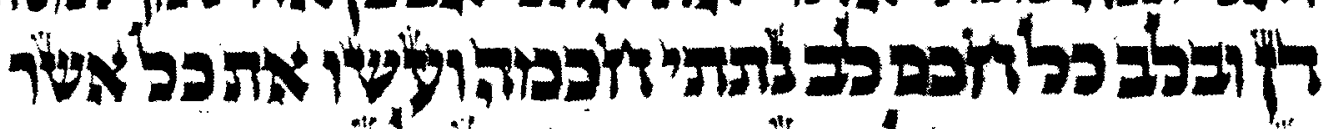

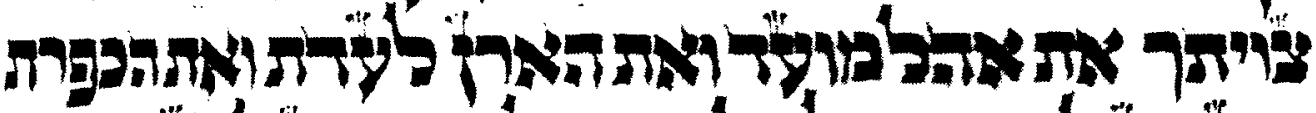

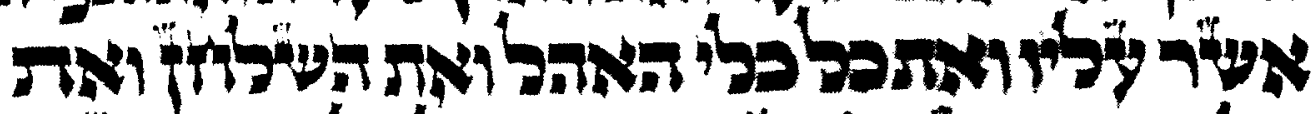

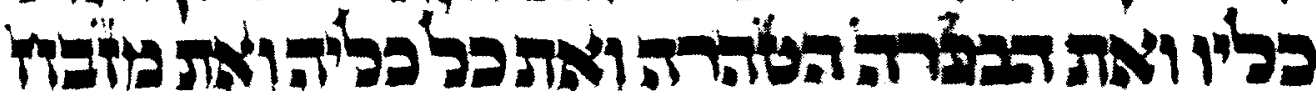

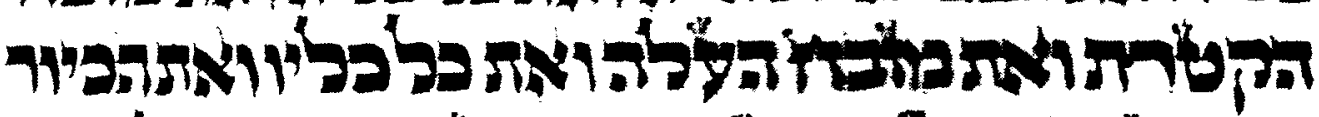
F.

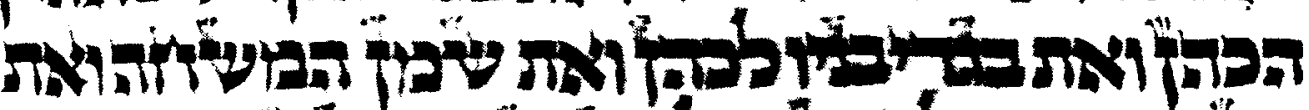

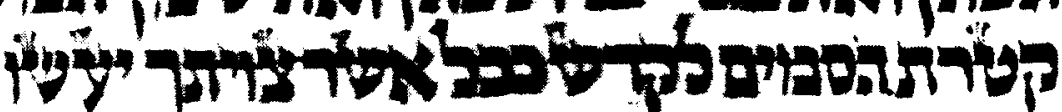

Figure - 34 (First Parshot revealing the Biblical Character of Bezalel, In K'Tav Beit Yosef (script for Torah use).

Source: Scharstein, Asher Ben David. Tikun La-Kor'im: Kolel Hamsah Humshe Torah Hoboken, NJ: Ktav Publishing House Inc. 1969 
The past chapter described five "Jewish" design interventions: i. Creating Halachic space by using both 3D modeling tools and concepts from the Torah. ii. Geometry designed by an excercise in using Biblical Hebrew words and the 231 gates illustration. iii. The trope pitch diagram as a concept for architectural space. iv. Using the form of the "Seal of Solomon" to create inherent proportions related to arch design. v. Establishing the properties of a light shading devise related to the Parsha which first describes the biblical character of Bezalel. These design interventions embedded in Jewish theoretical symbolism will be further illustrated in their application with a design for the Bezalel Academy of Art Design. In the following chapter a case will be made for combining traditional cultural indicators with contemporary architecture. 


\section{; The John Zorn Approah}

John Zorn began his music career as an avant-garde musician on the Lower East Side in New York city, otherwise known as the Downtown Scene. Throughout his career he has pursued varied creative explorations, across genres and methods of composition.

"The idea of trying to give back to a tradition that you had taken from is a healthy one. ${ }^{139}$

Zorn, being Jewish, possibly felt a desire to contribute to Judaism culturally. In 1994 John Zorn released an album entitled $x$ (The Hebrew letter "Aleph"). The Album was the first recording by a Zorn project called Masada. Perhaps Zorn's method of composition has the potential to cross artistic disciplines.

The question of combining certain elements of the modern building practice associated with the architectural language of the state of Israel, while introducing Jewish traditional or non traditional, religious or secular concepts, began by listening to Zorn. A Hypothesis formed to layer reading of these contextual and traditional variables expressing them through a series of architectural decisions. "Radical Jewish Culture" the larger body of contemporary Jewish music by Zorn and other Tzadik label

\footnotetext{
${ }^{39}$ BBC Zorn: A Radio Documentary CD2 London, UK: BBC Radio 2000, Track 3
} 
musicians gave further indication of what was meant by contemporary Jewish music, and therefore what could be used for contemporary Jewish architecture. Zorn's format for Masada and related recordings developed from an effort to combine his contemporary avant-garde musical background with Jewish musical motifs.

\begin{abstract}
"Masada ... basically is trying to create a new idea of what Jewish music could be by putting different ideas and influences together ... I was taking phrases in different keys, using these scales and manipulating them in different ways and trying to find a way for them to work together in some organic way, and it was very much a matter of taking a phrase here and a phrase there and scratching this one out and then moving this around. Really like playing with building blocks to create one organic melody. "40
\end{abstract}

Zorn approaches his project in contemporary Jewish music where his tools as an artist are a part of his being (and being Jewish). Zorn's training within the realms of punk, classical, and avant-garde music are no less a part of his "Jewishness" than the traditional elements of Ashkenazi Jewishness. Here Zorn's "Jewishness" exemplifies his compositional approach to writing contemporary Jewish music for Masada. Zorn creates a music that touches on both his contemporary background as a musician from New York while weaving thematic Jewish melodies as central ideas to his expression.

\footnotetext{
${ }^{40}$ Improv 21. Q+A: An Informance with John Zorn (2007) Internet: http://archive.org/details/IMP_2007_11_15, November 15, 2007 [May 26th 2012] 12:49/79:34 to $16: 01 / 79: 39$
} 
" Whenever people talk about Jewish music they're saying they mean Klezmer...Is that really the same, or is that different?... So we started thinking well...what can Jewish music do, what is Jewish music? What makes something Jewish?...What does that really mean? How can we reconnect? How can we take our culture and bring it into a new century $?^{141}$

The questions that unfold as Zorn generates a meaning for the term "Jewish Music", carry over to many parallels within greater Jewish culture and identity. Does the popular Jewish identity attach to the religious Ashkenazi traditions because these traditions are the most visually prominent? Do these Ashkenazi traditions appear as weak due to the events of the Holocaust, or a part of a greater truth in religious stamina? Is it progressive, forward thinking, or appropriate to throw away the past, or to hold onto it? Zorn creates his contemporary Jewish music by responding to these questions in a typically Jewish manner. Using a contemporary set of tools (network of musicians, recording and distribution capabilities, jazz, punk, chamber and avant-garde music compositional methods) and combining with traditional tools (Jewish symbolism as album and song concept, niggunim, Jewish ornamentation) Zorn is able to

\footnotetext{
${ }^{41}$ Improv 21. Q+A: An Informance with John Zorn (2007) Internet: http://archive.org/details/IMP_2007_11_15, November 15, 2007 [May 26th 2012] 10:21/79:34 to $12: 31 / 79: 34$
} 
weave a new method for approaching Jewish culture and identity with contemporary society. This method isn't limited to music. One could start by asking what would this method produce when applied to a Jewish architectural identity?

listen to "Karaim" - source: Bar KoKhba Ensemble (John Zorn, Mark Feldman, Erik Friedlander, Greg Cohen, Kenny Wollesen) Bar Kokhba New York, NY: Tzadik Records, 1996, Disk 2 - Track 12

\&

listen to "Karet" - source: Masada String Trio (Mark Feldman, Erik Friedlander, Greg Cohen) The Circle Maker: Zevulun New York, NY: Tzadik Records, 1998, Disk 1 - Track 3 


\section{Design Interventions in Practice}

The strategy in applying the interventions based in Jewish theological and cultural theory, was to design a pragmatic layout of required programmatic spaces, and layer each of the Jewish design interventions within the building starting with the volume of the written name Bezalel. The programmatic proposal is divided into twelve faculties in accordance with the requirements for the Bezalel Academy Competition brief. The programmatic layout, imagined as a conventional 'box', facilitates the housing of the 'Jewish' volumetric intervention within the central part of the building, unifying all the differing faculties by means of: light, air, circulation, and shared or public spaces. Through a series of design iterations it was noted that each faculty has a number of similarly required spaces: studios, offices, washrooms, etc., and that the differing programmatic spaces between each could be arranged within faculties requiring less overall space. As a result a two floor faculty unit was designed by integrating each of the similarly required spaces. In this manner the twelve faculties are contained within four floors, with a common floor spaced between them [see figures: 35, 37, 38].

The faculty units are spaced in a division of six per faculty floor, and are accessed by six independent vertical circulation towers. In section [see figure: 37] the open concept floors are staggered with floor to ceiling trusses. By having an open concept floor, the first floor of each faculty 
unit becomes flexible in both studio space and in having the ability to install and remove temporary partitions as the school changes with future programmatic requirements. Each of the open concept floors contain: a student cafe \& exhibition space, bathrooms, a classroom, two faculty office spaces, and an open studio space [see figure: 36 ]. The floor to ceiling truss floor plan houses the faculty space in need of delineation and of a more permanent nature, such as: the head office, secretary, the majority of faculty offices, classrooms, bathrooms, critique rooms, and drawing rooms [see figure: 38]. For certain faculties, such as Cinema school, the truss floor contains small spaces required for editing rooms and stop motion footage rooms.

The common floor contains: a library, daycare, auditorium, theatre, restaurant spaces, and circulation servicing both the public and the academy[see figure: 40]. Placed Centrally, in section, these common programmatic spaces contribute to the unifying element of the circulation path. By cutting through the school, the circulation path will act as a tool in bringing the greater public in contact with the academy, and vice versa. In the following sections of this chapter the previously proposed design interventions will be illustrated in context with the design of the Bezalel Academy. 



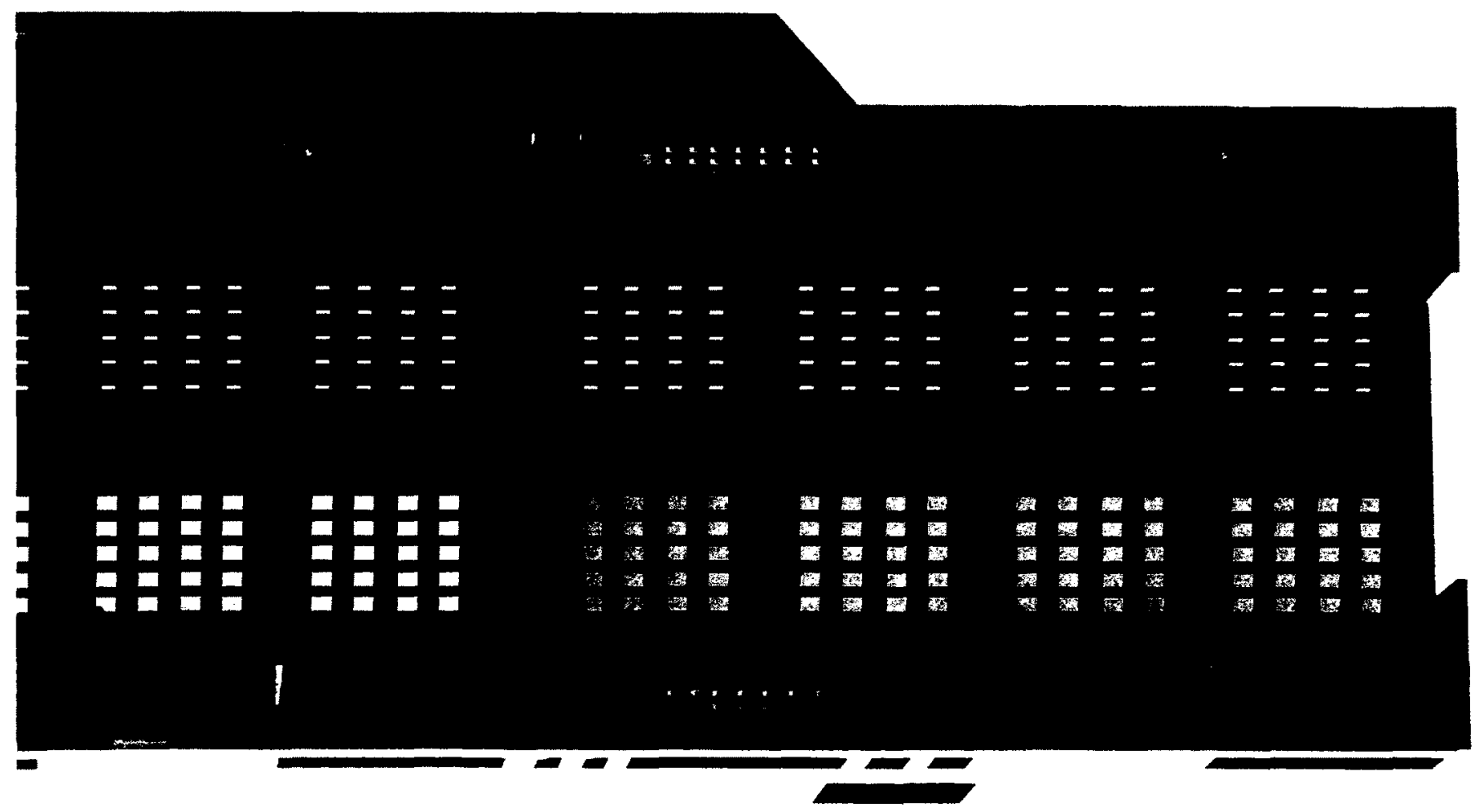

Figure - 35 / Open concept axonometric floor plan with Fine Arts faculty in colour. IIIustration by the author. 


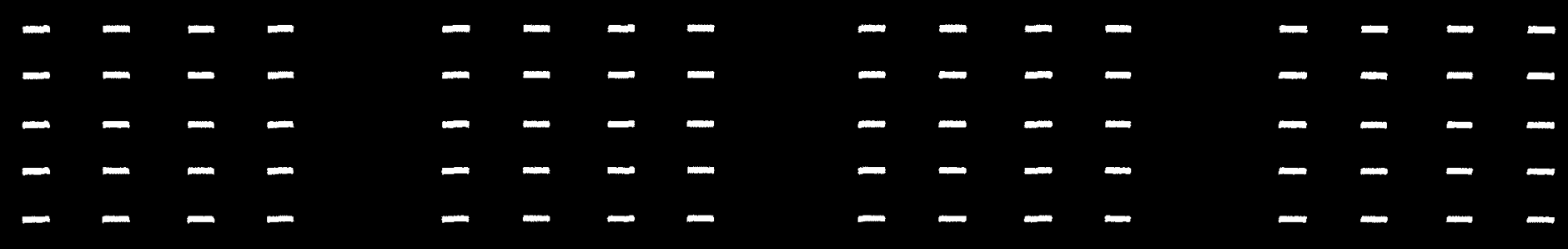

用围建遇围围

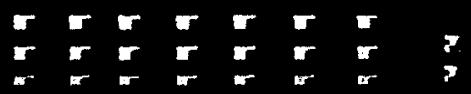

Figure - 36 | Open concept axonometric floor plan faculty detail. Illustration by the author. 


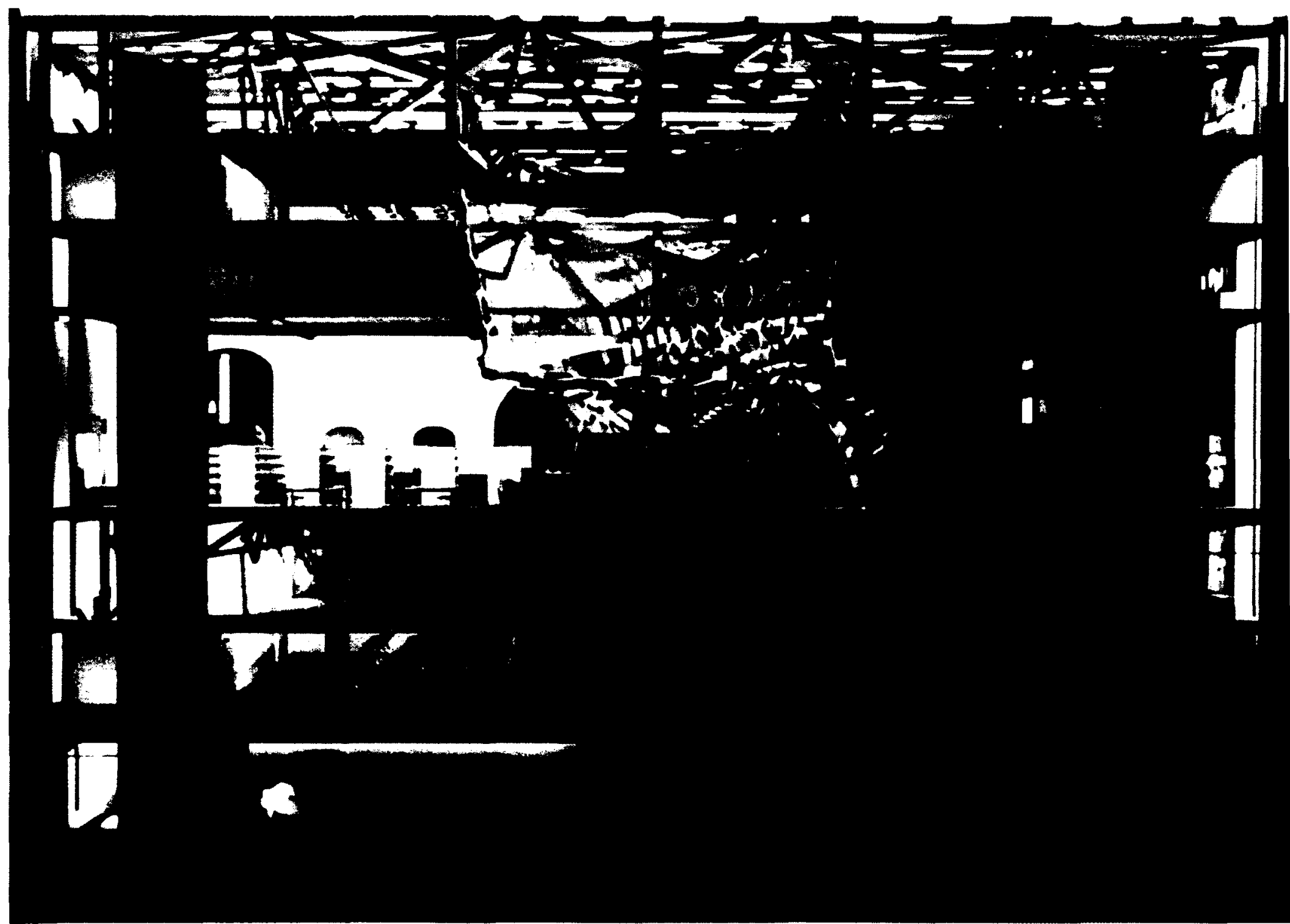

Figure - 37 / Cross Section with two level Faculty unit (Open Concept \& Truss Floor)in colour. Illustration by the author. 



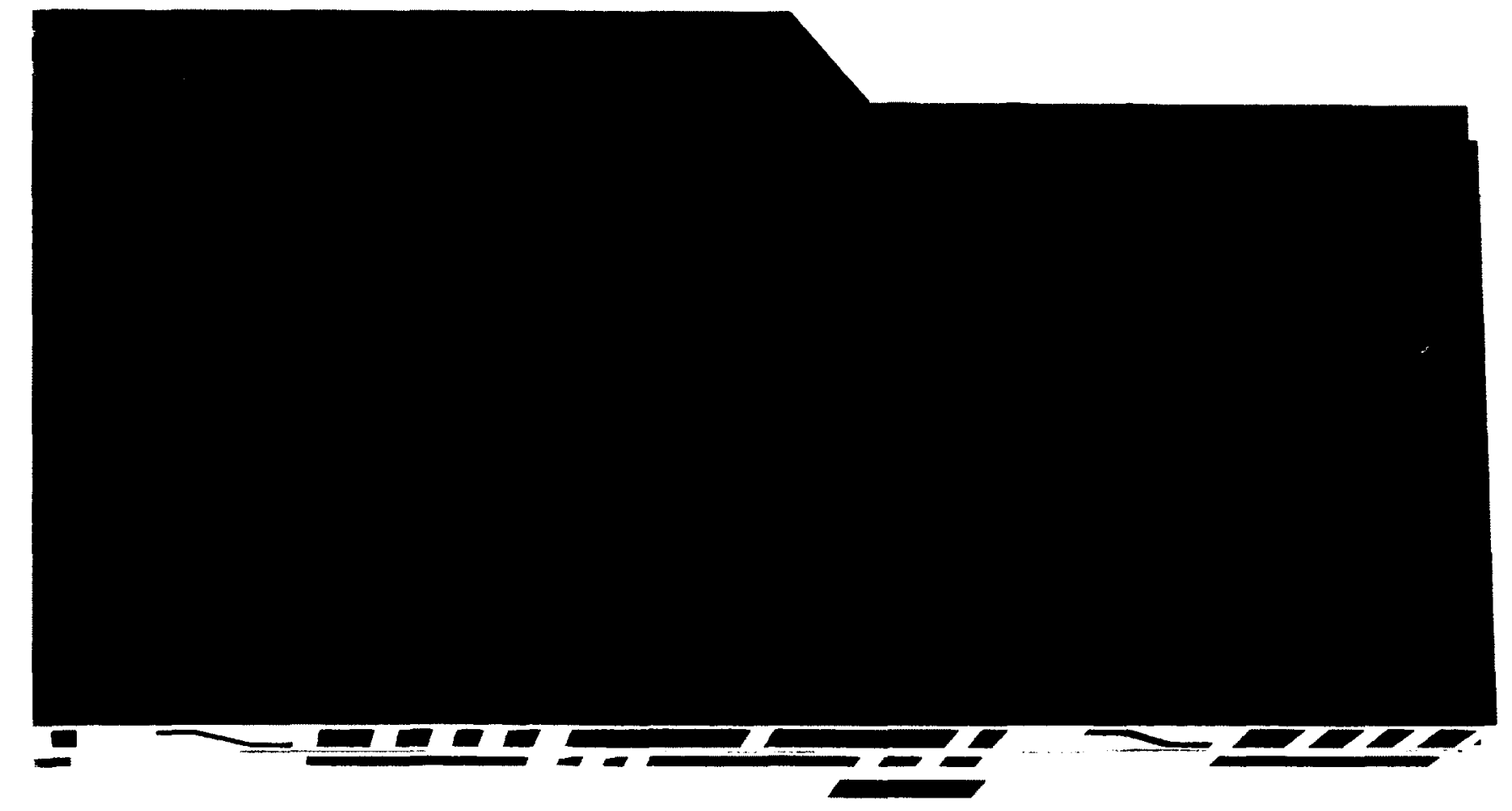

Figure - 38 / Truss layout axonometric floor plan with second floor of Fine Arts faculty in colour. Illustration by the author. 



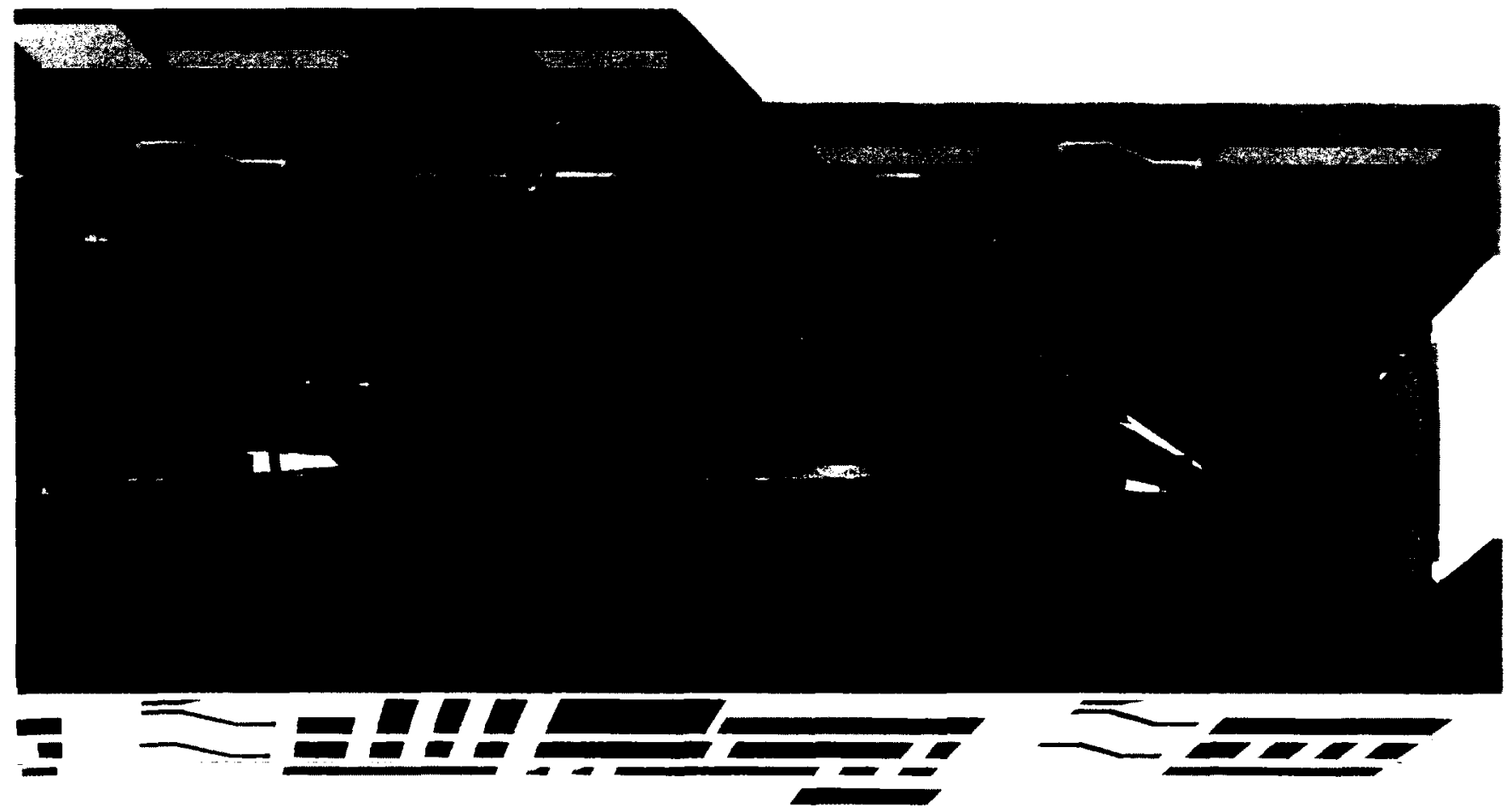

Figure - 40 / Axonometric floor plan Common Spaces. Illustration by the author. 


\section{i. Hidden Between The Letters Of Bezalel}

As mentioned the volume connecting the programmatic elements of the building, unifies the diverse spaces by its designation of being both shared within the school and public amongst the neighboring community. The volume is open on both ends of the building, acting as a bridge between the components of the school, and inviting the neighboring community to cut through the building, bridging both the school with its functions and the greater city with the school.

Three structural definitions were explored. Firstly, the Bezalel volume, was converted into a 3ds Max file. Using a modifier tool called lattice, the wireframe of the initial lofted form is converted to a structure with a thickness [see figure: 41]. The drawbacks in using the lattice modifier relate to the lack of control, aside from the thickness modification of the frame created. Consequently, as a design tool, the Lattice modifier tended to be somewhat uneven and unpredictable.

The second method explored a modifier called subdivision, where each vertice (point) within the form is converted into a polygon with surrounding segments and their defining vertices. These converted polygons would then be extended to their maximum size (constrained by the overall form \& their adjacent converted polygons). The faces of the polygons are then

deleted [see in red figure: 42]. The shell modifier is then added to the 
remaining wireframe, where thickness of the frame can be controlled. [see figure: 43] These steps tended to correct most of the drawbacks from the Lattice modifier exercise. However, the process of the subdivision modifier isn't precise in extending the polygon faces, and this creates an end result with wandering vertices [see in red figure: 44].

The third method used a plugin software for $3 d$ s Max entitled parametric array [see website: http://torabiarchitect.com/parametric-array]. The plugin has the ability to take a basic structural unit, in this case a hexagon, and apply the unit to a complex three dimensional form. In other words, the software connects the original hexagon unit to the $3 \mathrm{D}$ form by creating multiple copies covering the exterior, creating a structural skin from the original lofted geometry[see figure: 45$]$.

The parametric array structural definition allowed for a certain flexibility with the other components of the building. The array model, being of individual hexagon units, is easier to modify parts that require resolution due to intersection with other geometries. [see figures: 46, 47]. 


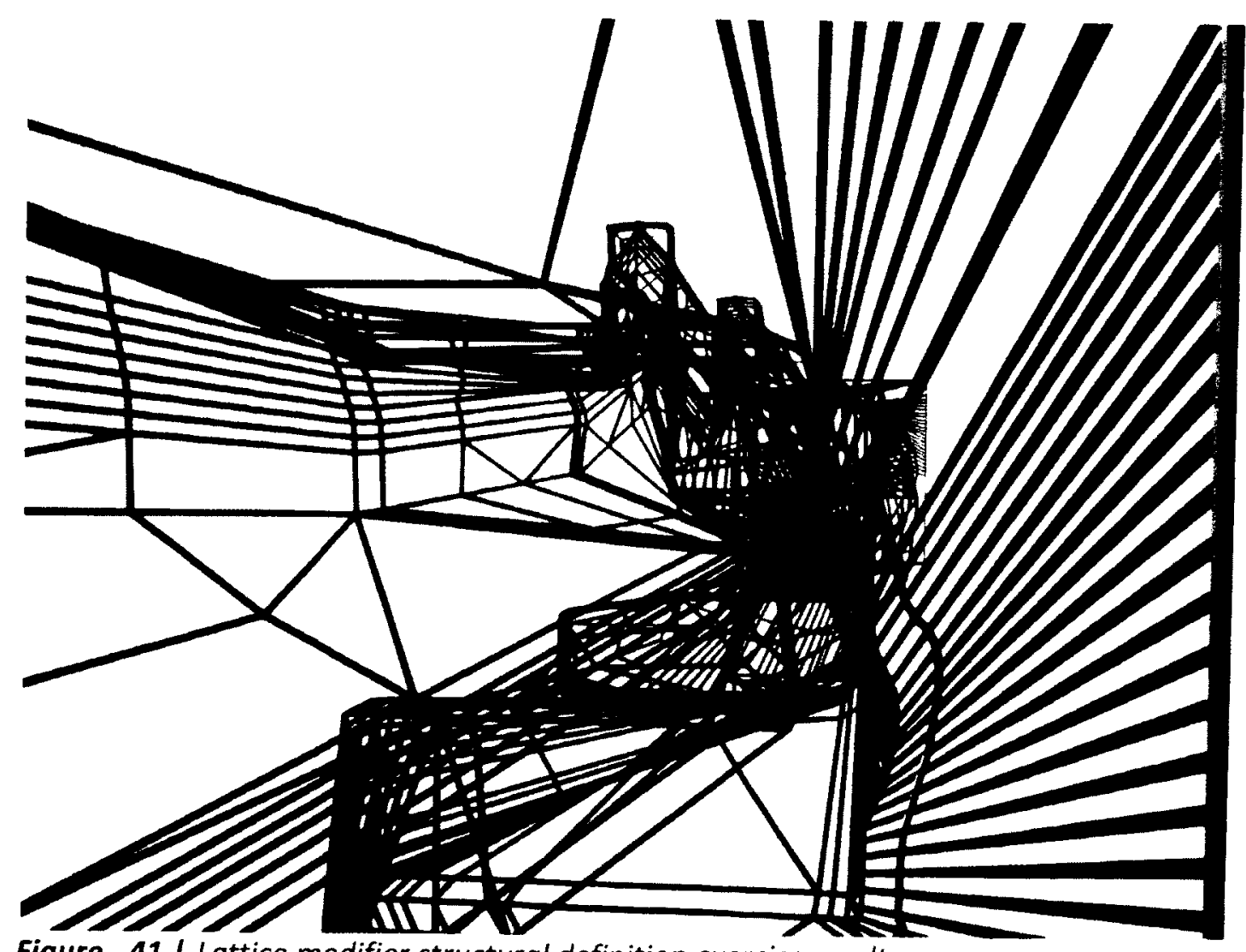

Figure - 41 / Lattice modifier structural definition exercise results.

Illustration by the author. 


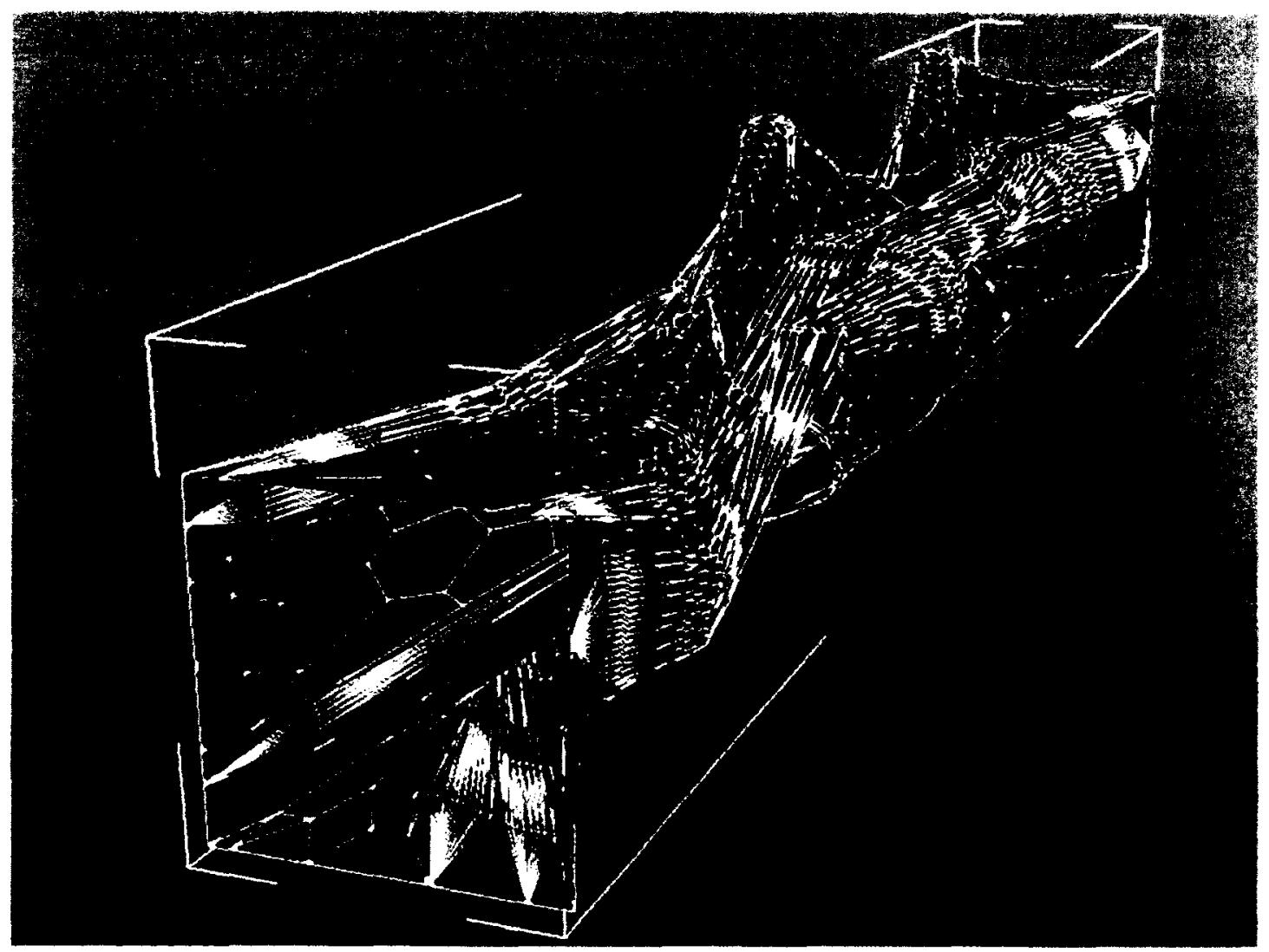

Figure - 42 / Sub Division modifier structural definition (pre polygon face deletion) exercise results. Illustration by the author. 


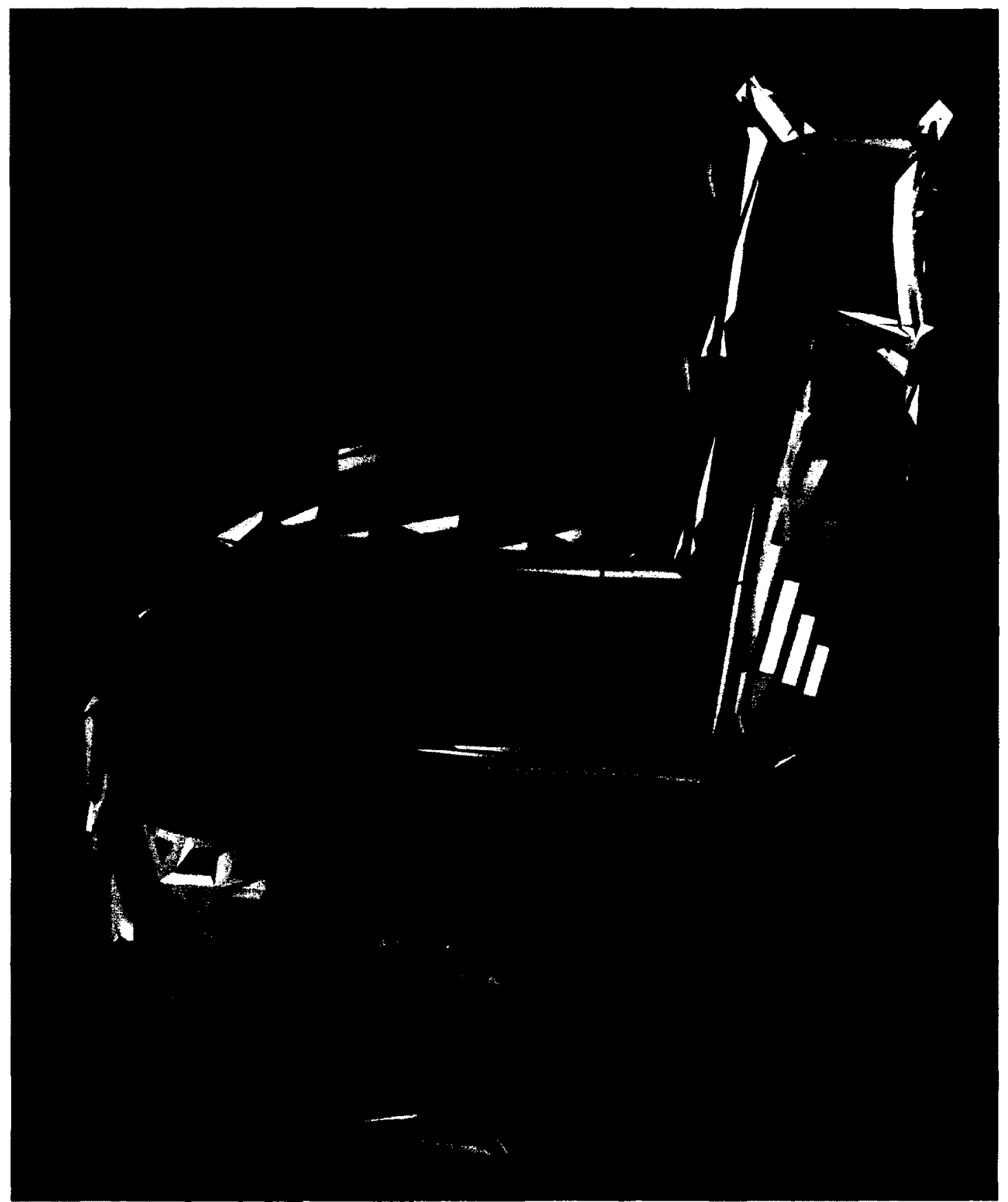

Figure - 43 / Sub Division modifier structural definition detail, exercise results.

Illustration by the author. 


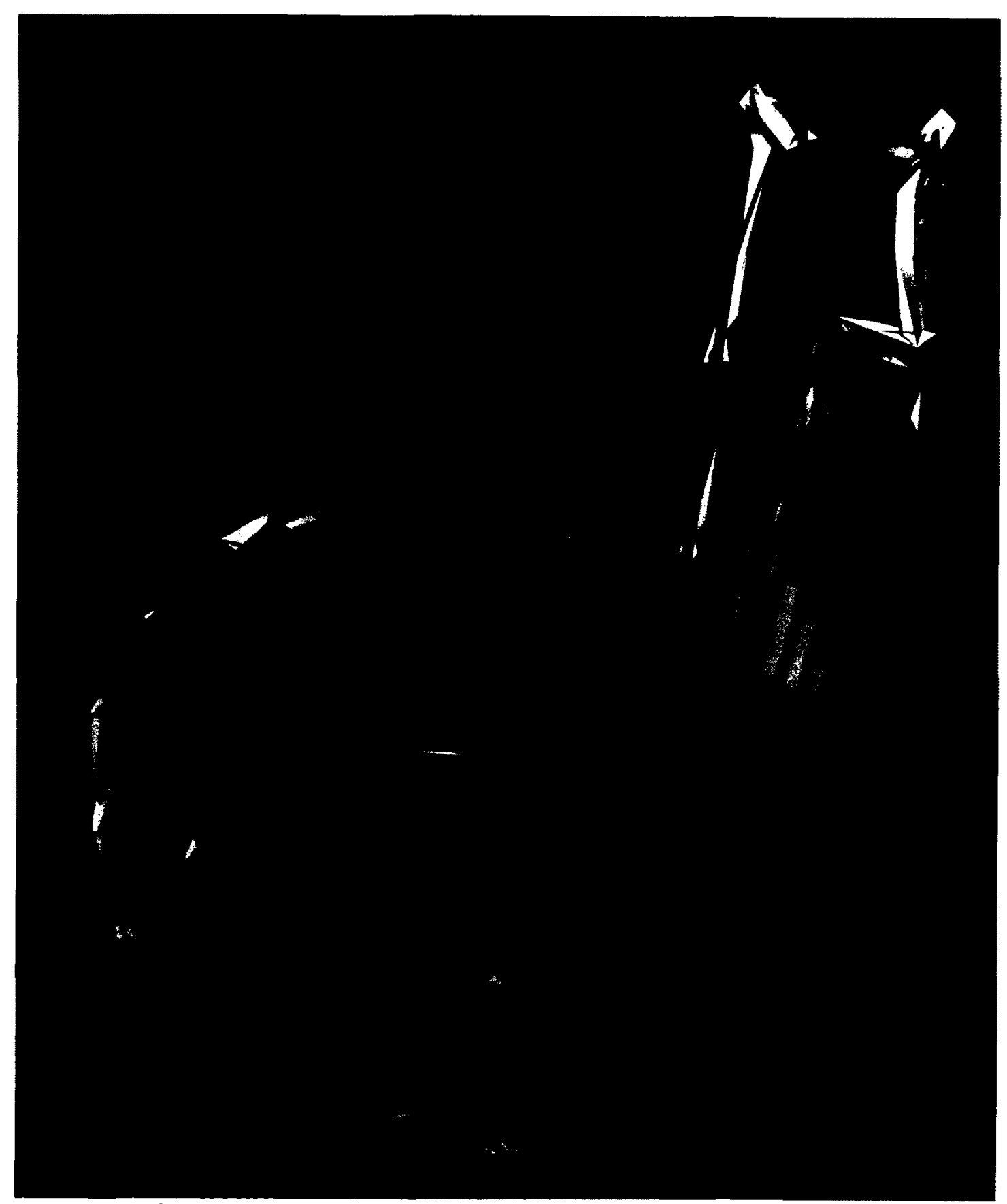

Figure - 44 / Sub Division modifier stray vertice detail, problematic areas. Illustration by the author. 


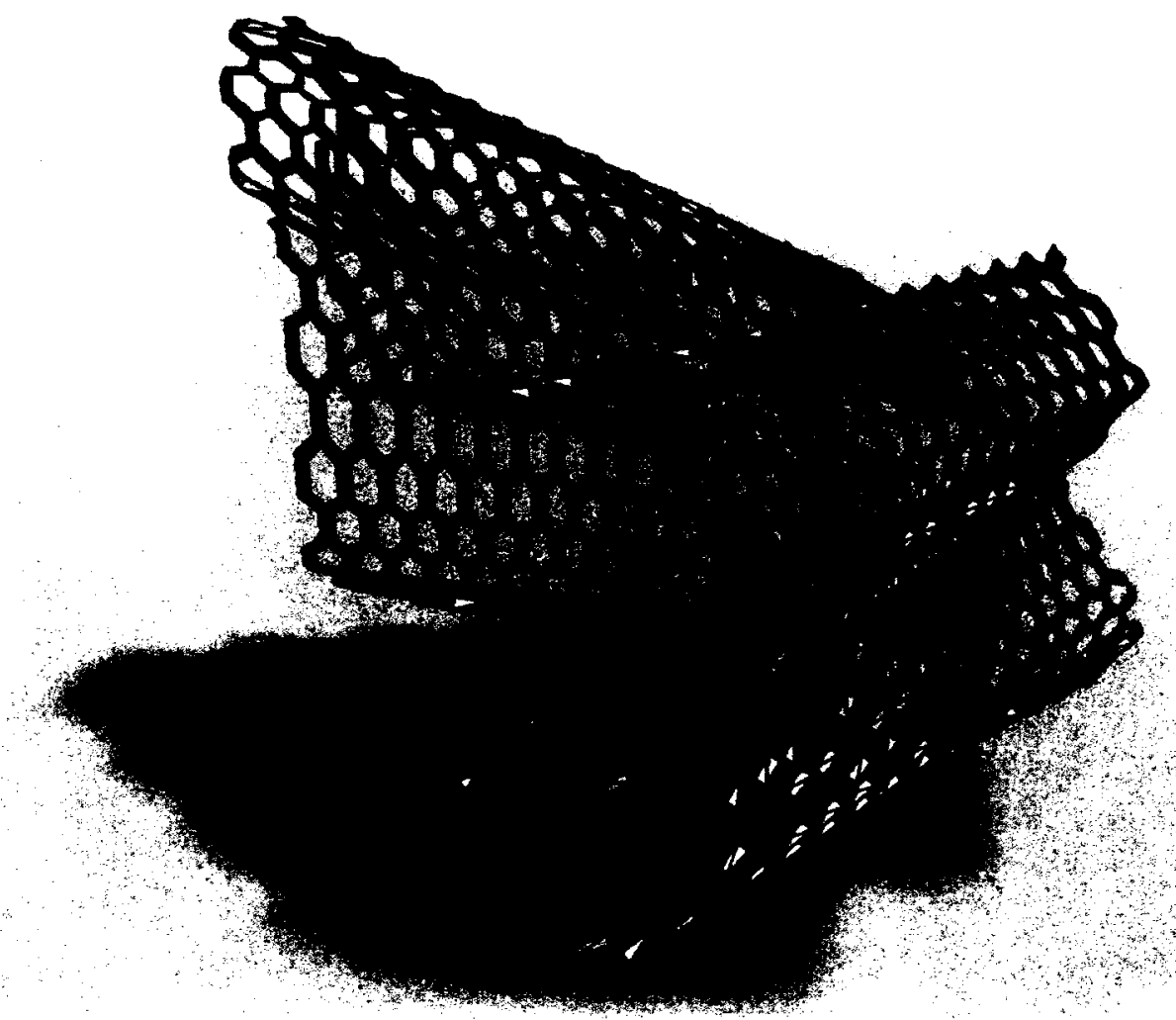

Figure - 45 / Parametric Array, exercise results. Illustration by the author. 



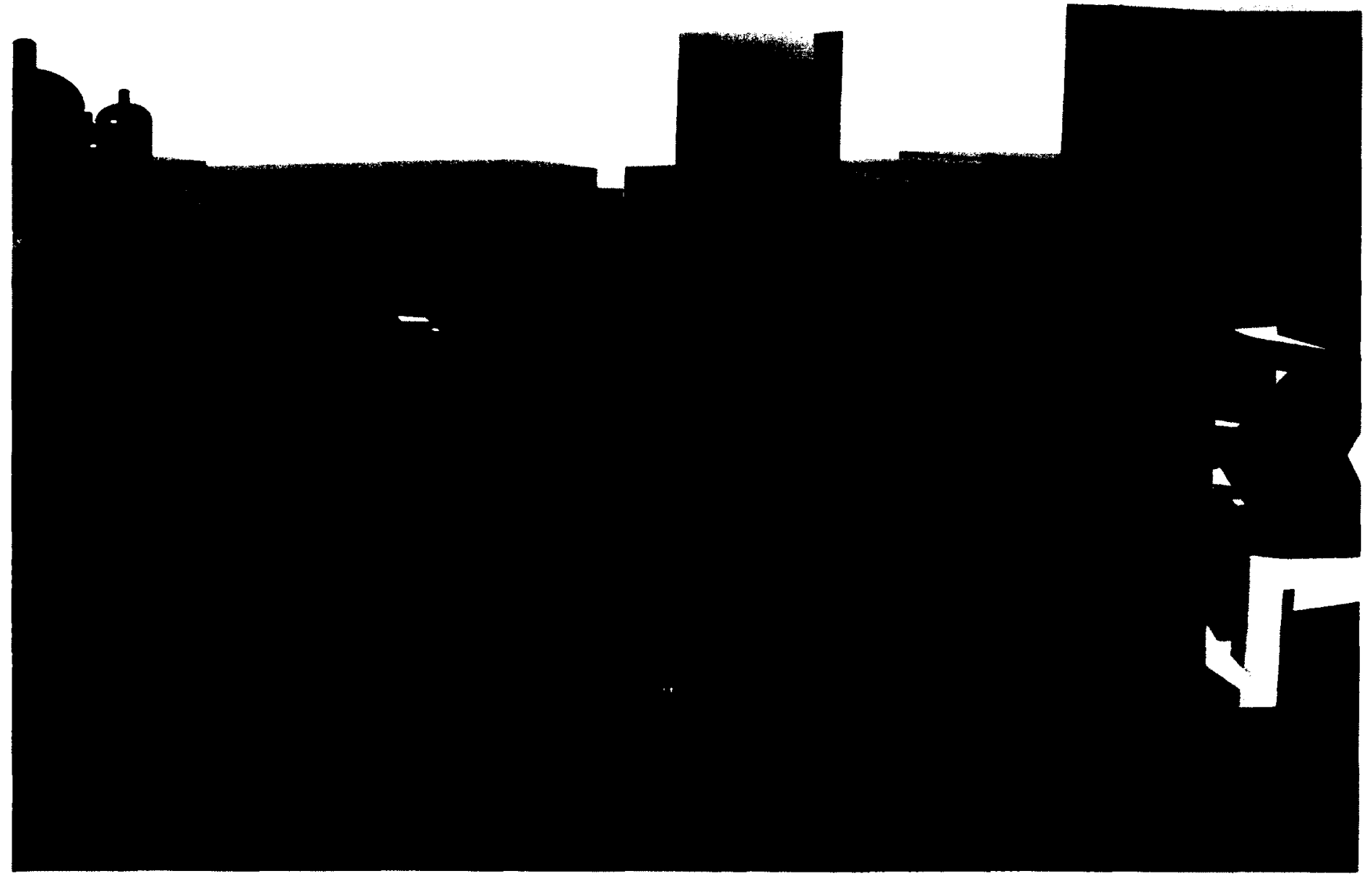

Figure - 46 / LongSection. Illustration by the author. 


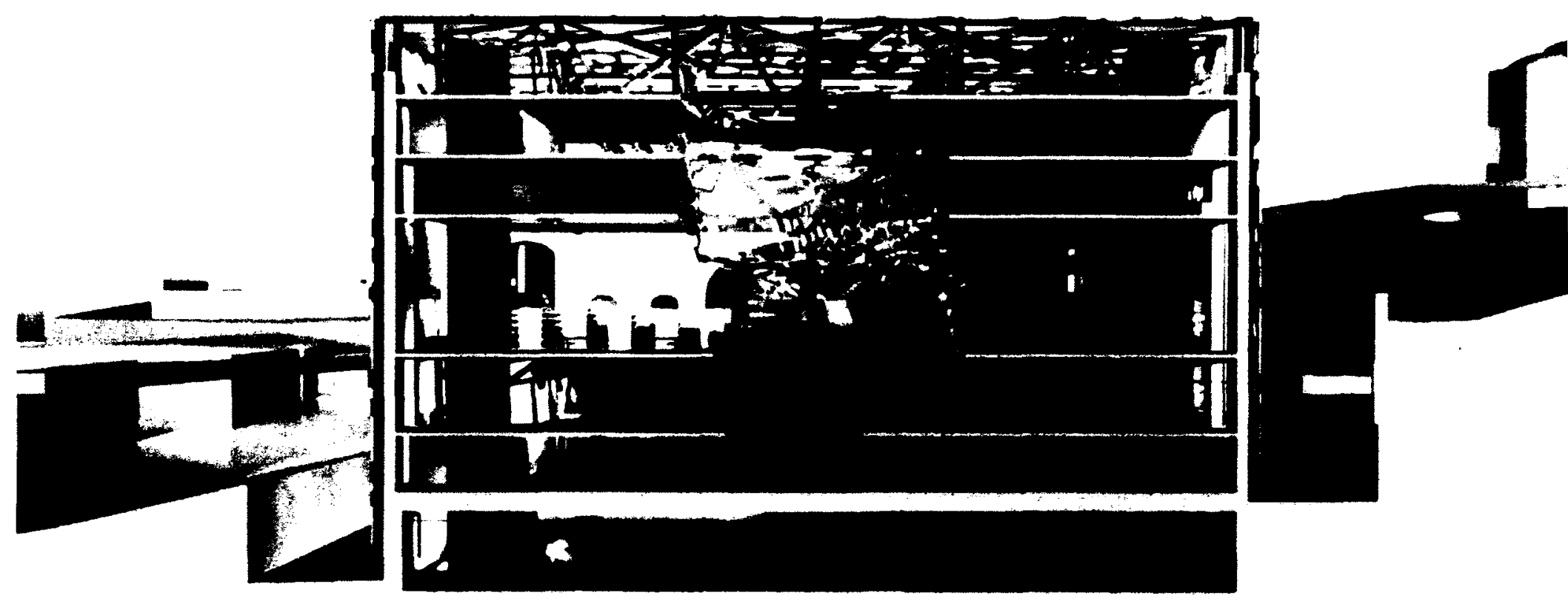

Figure - 47 / Short Section. IIlustration by the author. 


\section{ii. Oholiab, Theoretical and Geometrical Support}

In the Torah, in the same Parsha in which Bezalel is introduced, God designates a character by the name of אהליאב(Oholiab) as his assistant to the work:

"... behold, I have assigned him Oholiab son of Ahisamach of the tribe of Dan, and I have endowed the heart of every wise-hearted person with wisdom, and they shall make all that I have commanded you: the Tent of Meeting, the Ark of the Testimonial-tablets and the Cover... ${ }^{\text {A2 }}$

The observed support for Bezalel within the parable suggests that a supporting design intervention should point to the character of Oholiab. Using the diagram from Sepher Yitzirah and the letters in Oholiab's name, a two dimensional geometry is created [see figure: 48]. The wireframe geometry is then given depth and an extruded based on the required use/see figure: 49]. The geometry is then scaled and duplicated to create a truss fitting the dimensions of the required programmatic floor plan layout/see figure: 50]. On the truss floors the interior partitions are determined by the truss layout, while the geometry of the structure is displayed through the partitions by mounting semi-translucent plexiglass as space division on either side of the truss[see figure: 51 ].

\footnotetext{
${ }^{42}$ Scherman, Rabbi Nosson. The Chumash (the artscroll series/Stone edition) - The Torah: Haftoros and five Megillos with a commentary anthologized from rabbinic writngs Edited by Rabbi Hersh Goldwurm, Rabbi Avie Gold, and Rabbi Meir Zlotowitz. Brooklyn, NY: Mesorah Publications Ltd, 1993, pg. 491
} 


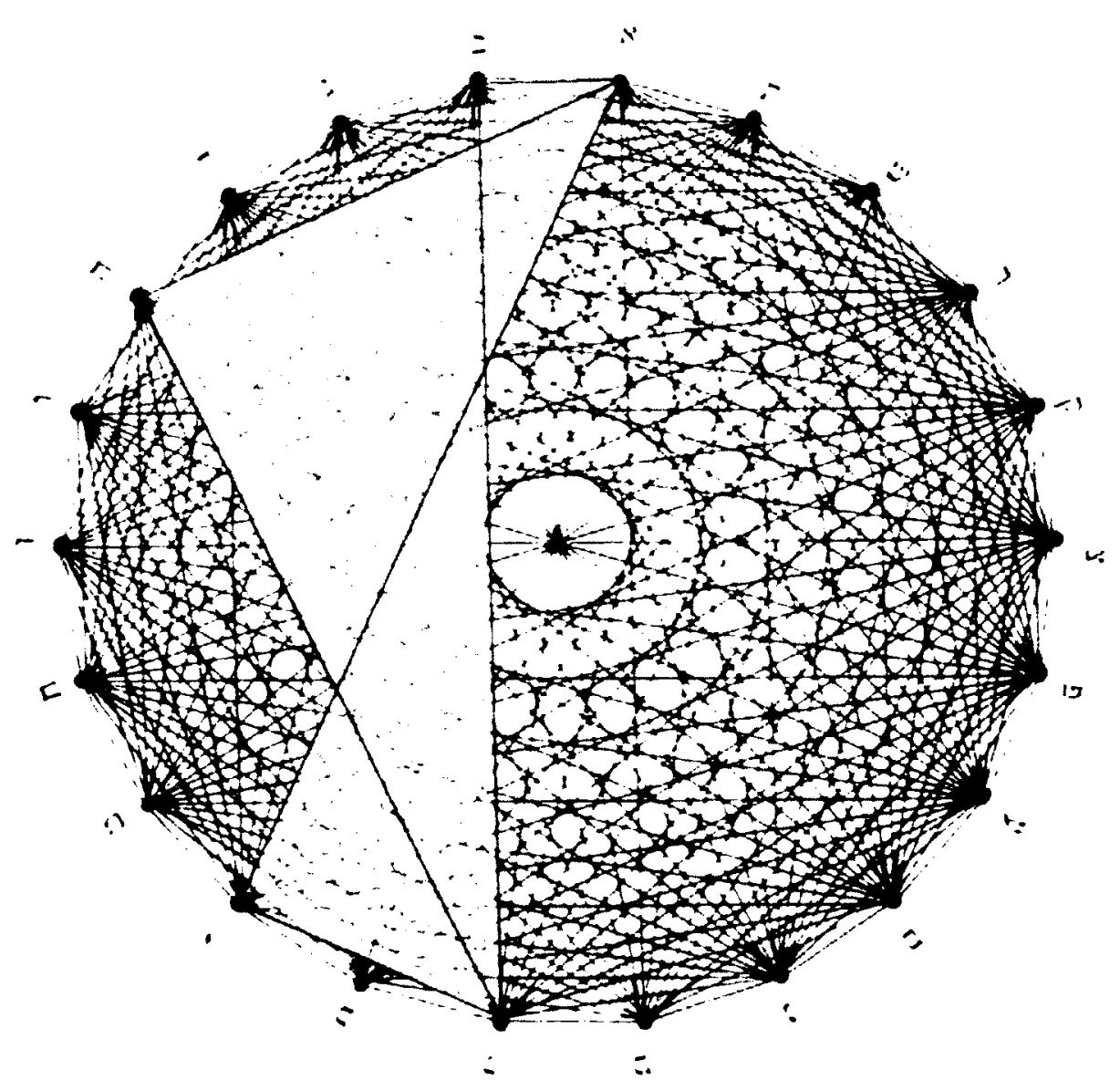

Figure - 48 / 231 Gates diagram, with the geometry for the name אהליאב (Oholiab). Illustration by the author \& Image from: Kaplan, Aryeh. Sefer Yetzirah The Book of Creation San Francisco, CA: Red Wheel/Weiser, LLC, 1997 


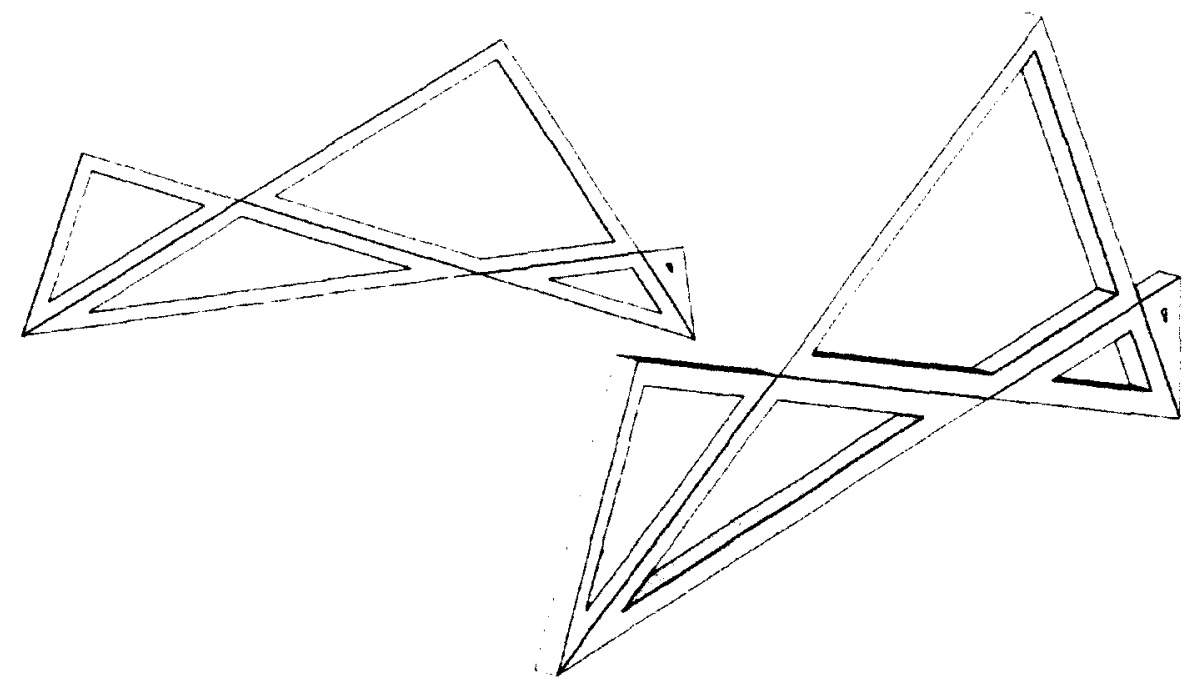

Figure - 49 | אהליאב (Oholiab) geometry extrusions. Illustration by the author.

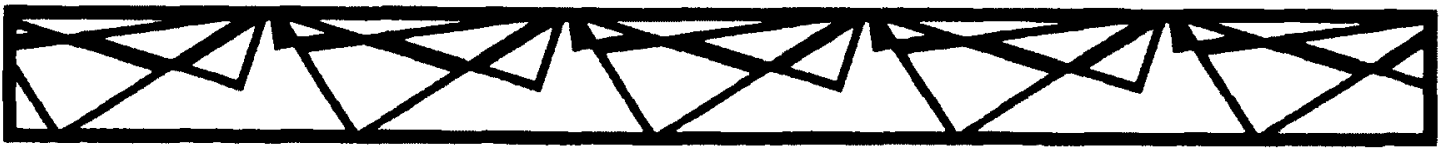

Figure - 50 / אהליאב (Oholiab) truss. Illustration by the author. 


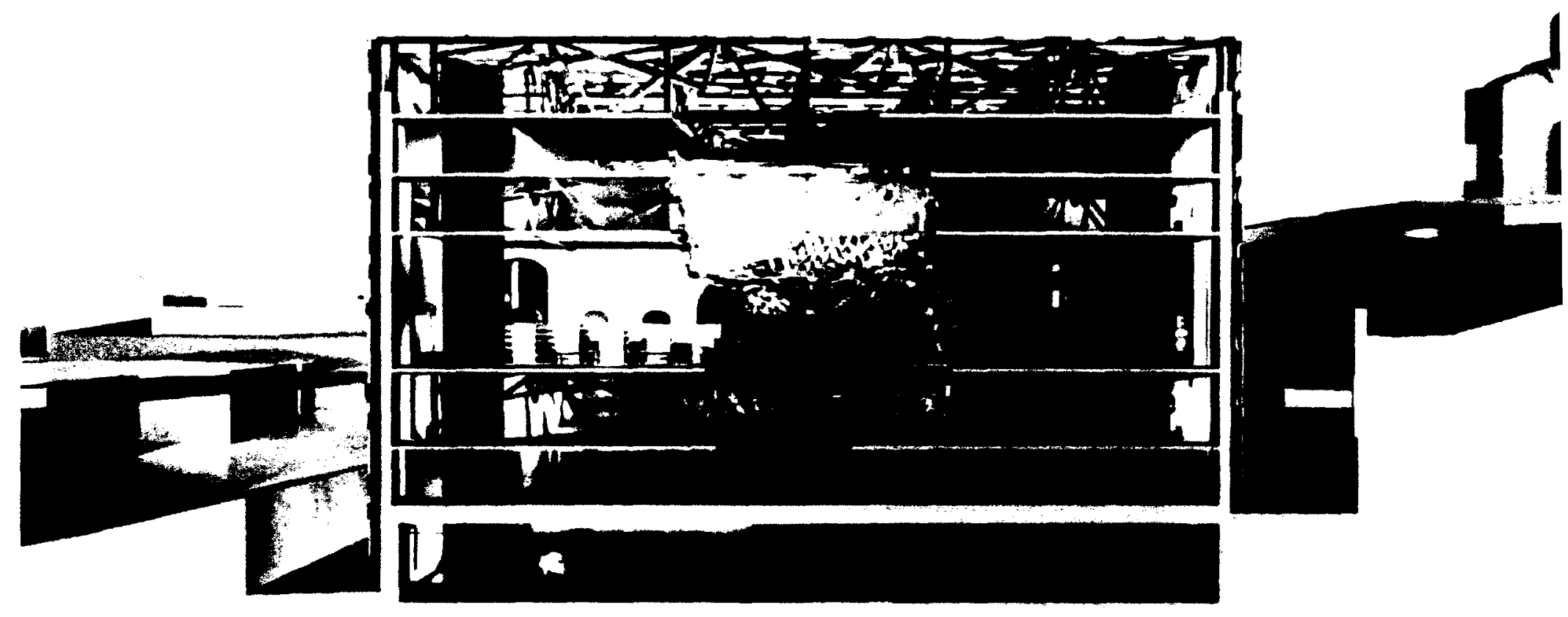

Figure - 51 / CrossSection. Illustration by the author. 


\section{iii. Circulation N'ginot}

Using n'ginot from the first Torah sentence in the paragraph that introduces Bezalel and by using the sketch illustration (by Cantor Emeritus David Aptowitzer, Agudath Israel Congregation of Ottawa) an alignment of the sketched n'ginot can then be abstracted as a proportional spacing diagram [see figure: 52]. The notated path could then be developed further by scaling the sketched dashes to an architectural scale [see figure: 53]. Programmatically, the path is assigned to the exterior/interior circulation which passes through the three dimensional volume generated from the proportions of the letters in the name Bezalel. Each platform (or note) housing a different function (including: daycare restaurant, cinema), brings interest to the school from the surrounding neighborhood and unifies the school faculties through shared program and circulation. [see figure: 54, 55] 


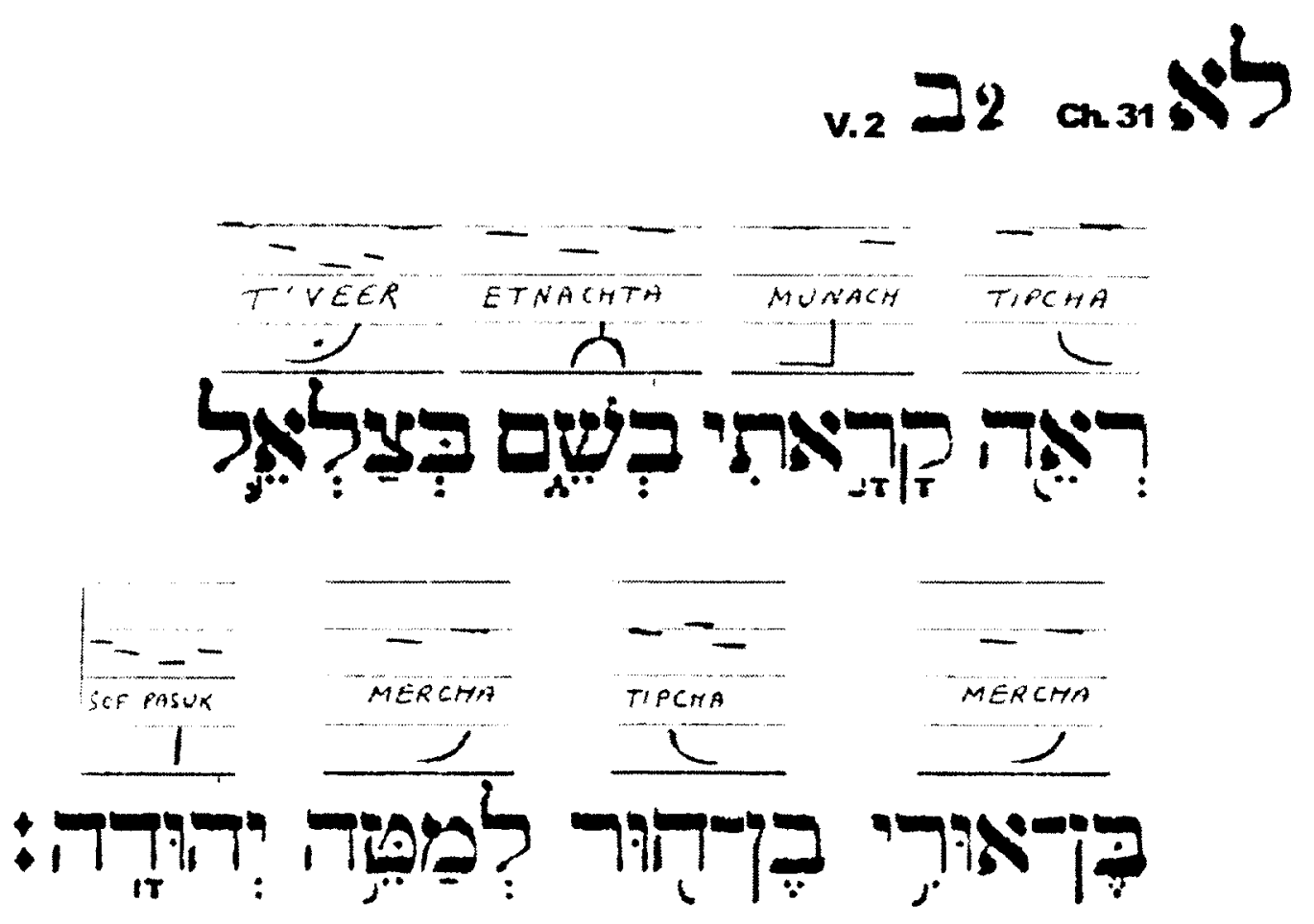

Figure - 52 / visual representation of the N'Ginot describing Bezalel. Illustration by the author using imagery from Figure - 23 \& Text: Scharstein, Asher Ben David. Tikun La-Kor'im: Kolel Hamsah Humshe Torah Hoboken, NJ: Ktav Publishing House Inc. 1969 

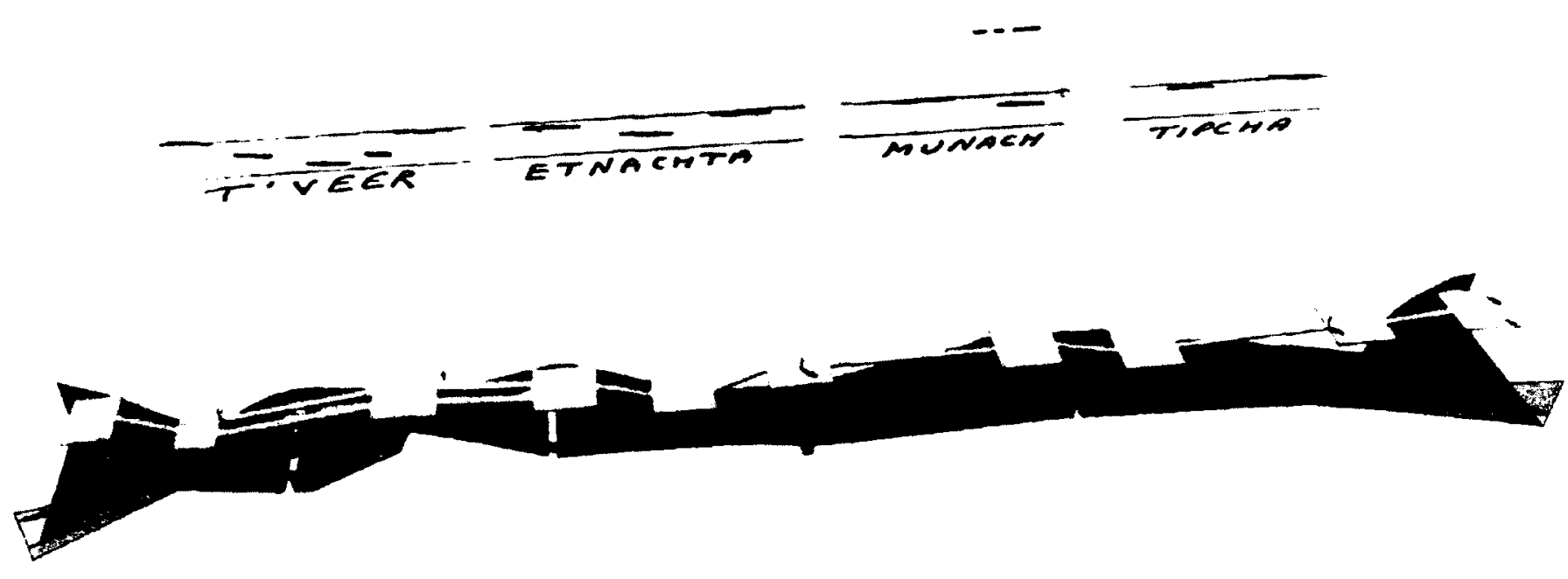

Figure - 53 / Extruding and scaleing the N'Ginot of Bezalel. Illustration by the author. 


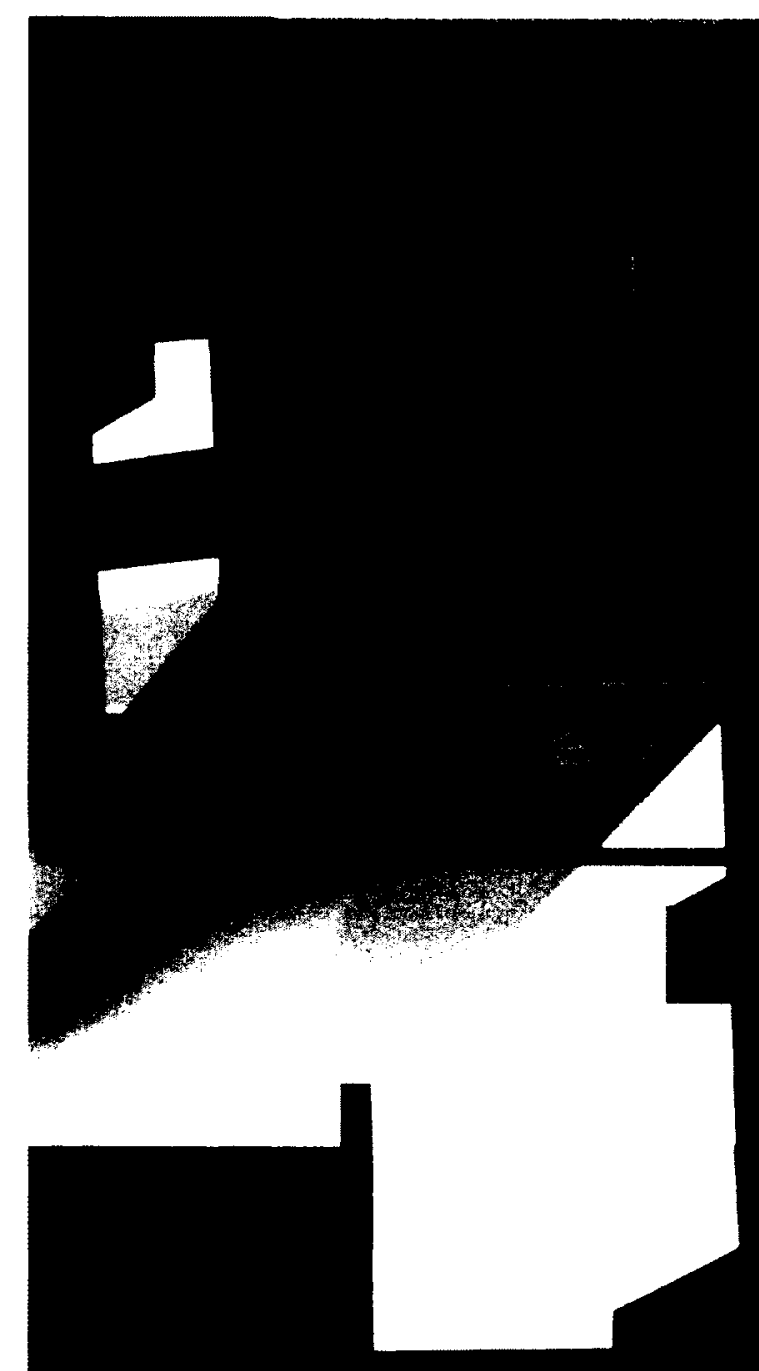

Figure -54 / Section with Circulation path in colour. Illustration by the author. 
Figure - 55 / Section with Circulation path in colour. Illustration by the author. 


\section{iv. Seal Of Solomon Imbedded In The Heart}

Within this design proposal there are two main interior load bearing structural walls made from Jerusalem Stone [see figure: 56]. Both the material and the function with which the walls are supporting the building reflects contextual strength in relationship with the greater city-scape. The arch design intervention is applied as a means of dimensioning the openings within these structural walls[see figure: 57]. Through proportion, dimensioning, and material, selected thresholds through the walls have inherent relationships to the city of Jerusalem and King Solomon's Seal. 


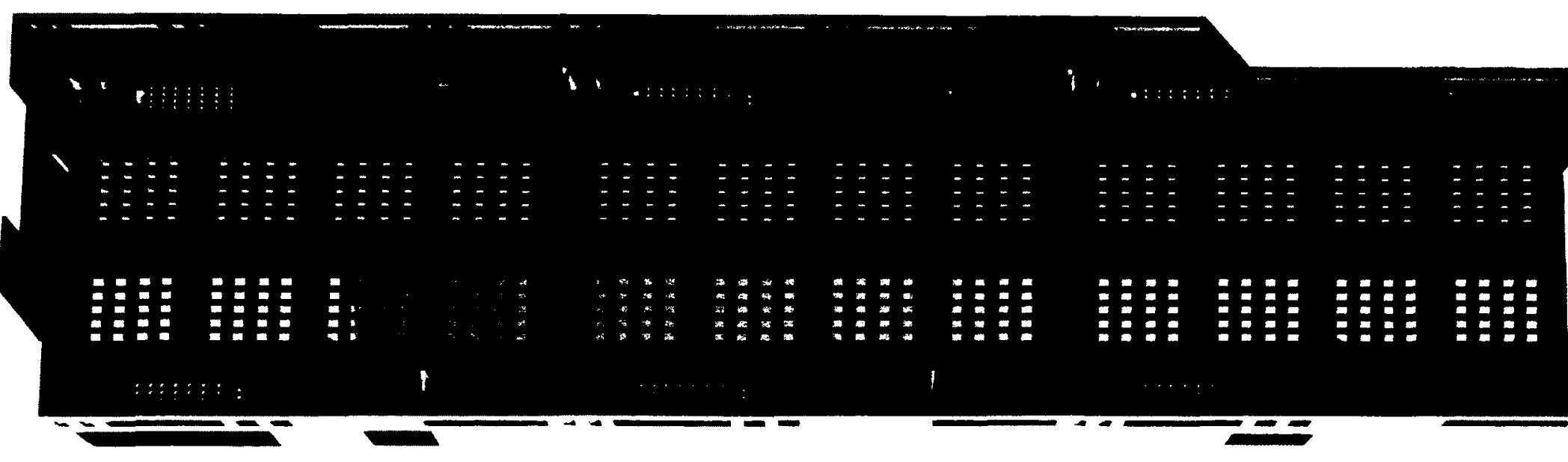

Figure - 56 | Axonometric plan with load bearing walls in colour. Illustration by the author. 


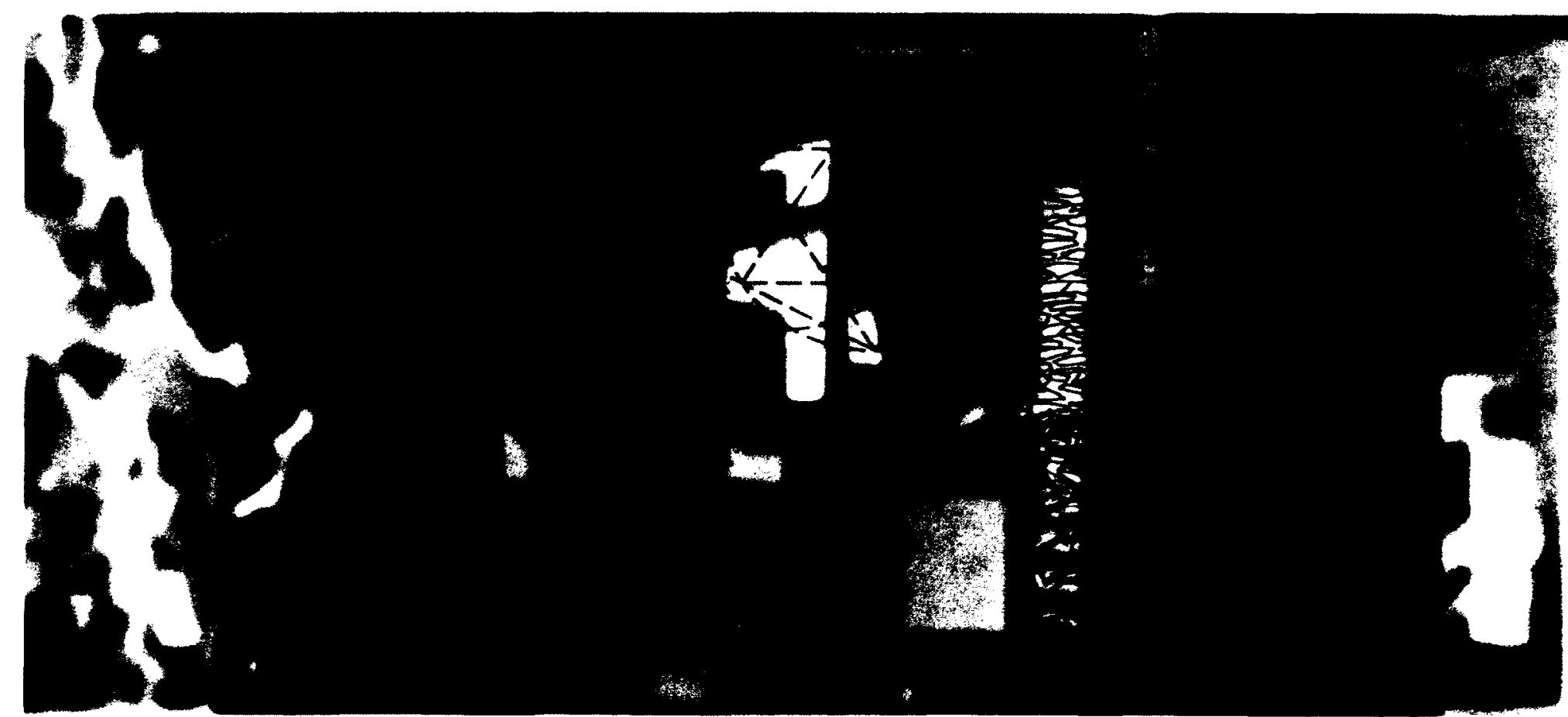

Figure -57 / Arch proportion representation. Illustration by the author. 


\section{v. The Wrapping And Projecting Of Halachic Light}

Drawing from the first Torah portion where the name Bezalel is mentioned, each letter is carefully traced in Sketchup to replicate the K'Tav Beit Yosef script [see figure: 58, 59]. These Traced letters become outlines on the surface of a panel. Once on the panel the outlines can then be made into openings by extrusion [see figure: 60]. By dividing the content of the Torah portion into key mentioned concepts (Bezalel's special wisdom and knowledge, the types of trades in which Bezalel is gifted, Bezalel's assistant Oholiab, etc.) panels of interest are traced, and fitted to wrap the building in a passive cooling shading device [see figure: 61 ]. This shading device creates a highly detailed abstraction of the Sopher's letter proportion accuracies, shaping the light as it enters the building in day time, and sculpting the man made light as it leaves the building at night [see figures: 62, 63]. 

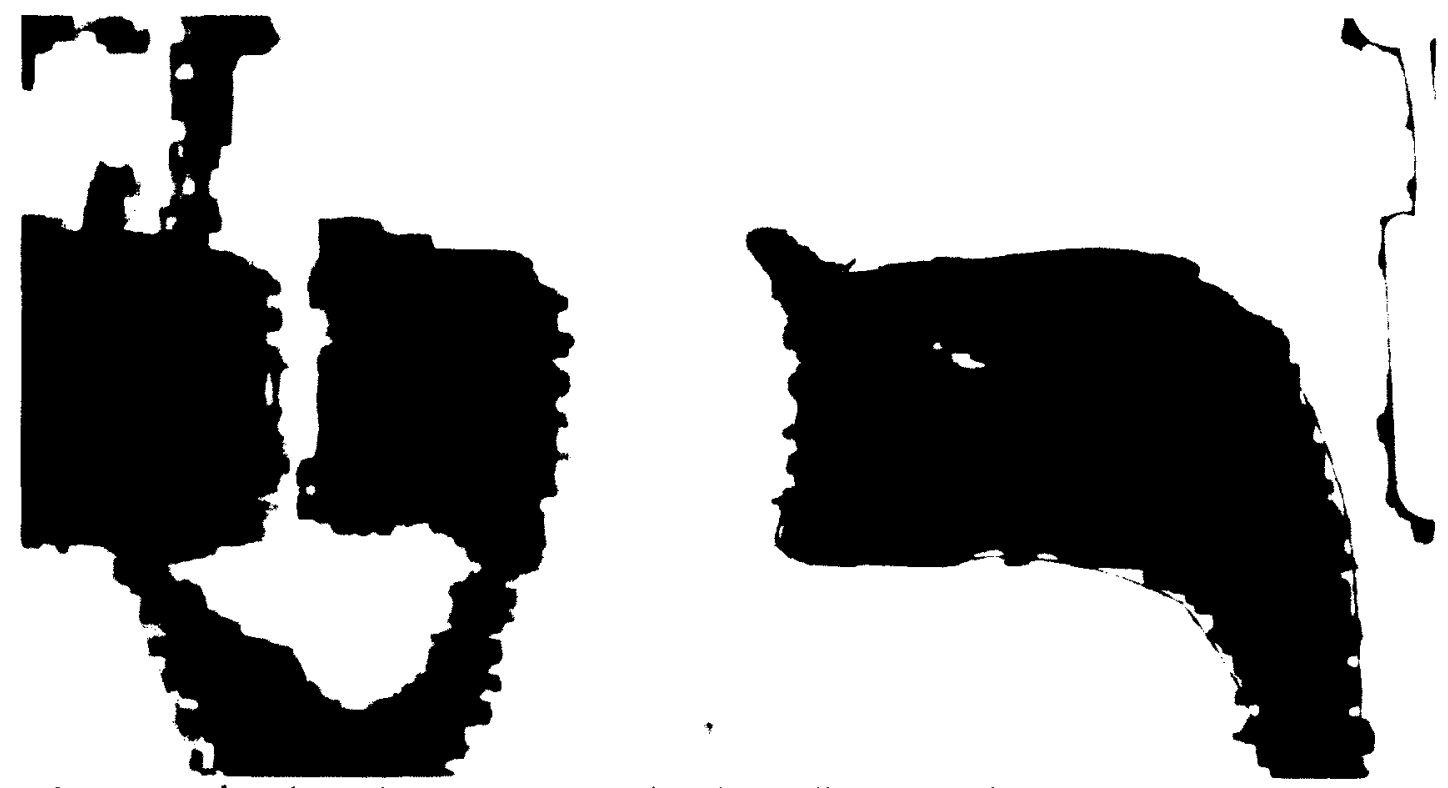

Figure - 58 / Hebrew letter tracing in sketchup. Illustration by the author.
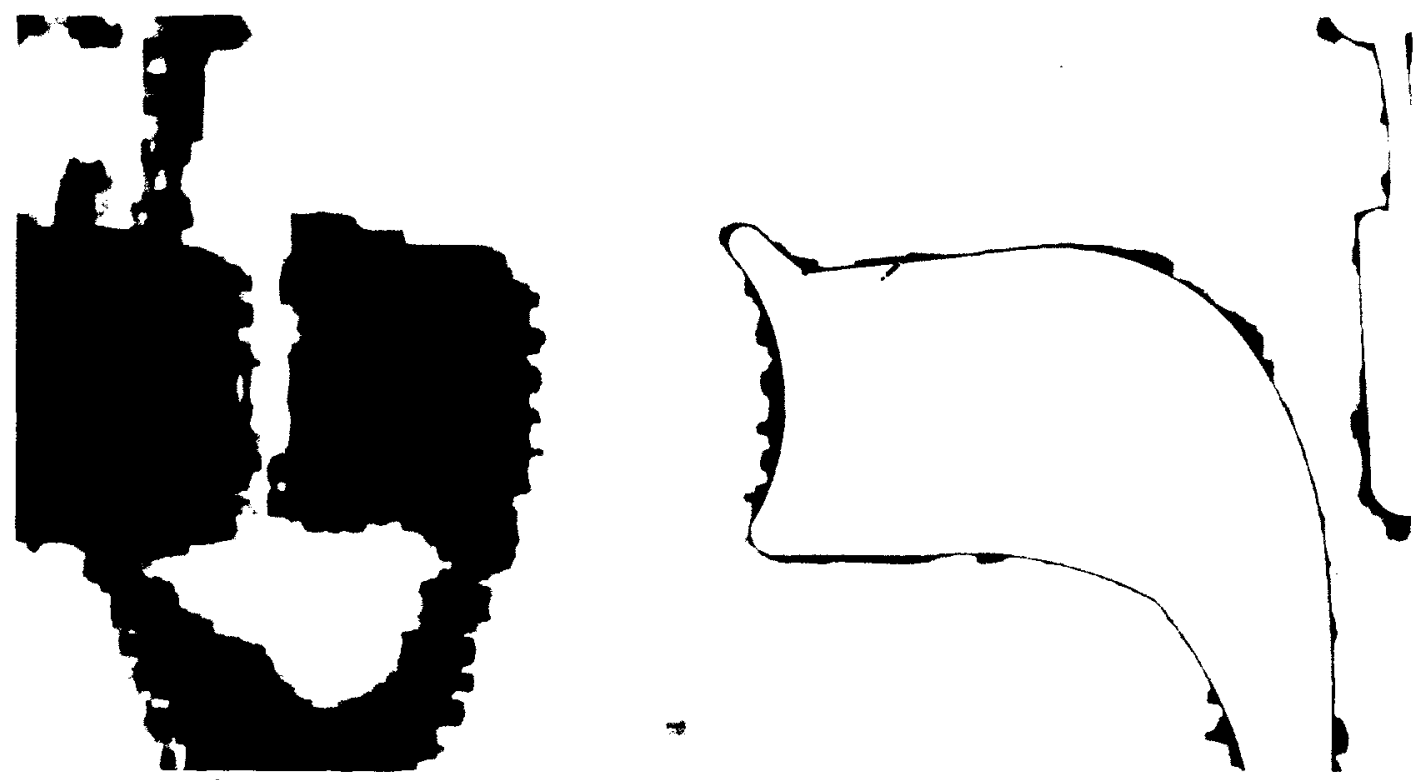

Figure - 59 / Hebrew letter tracing in sketchup. Illustration by the author. 


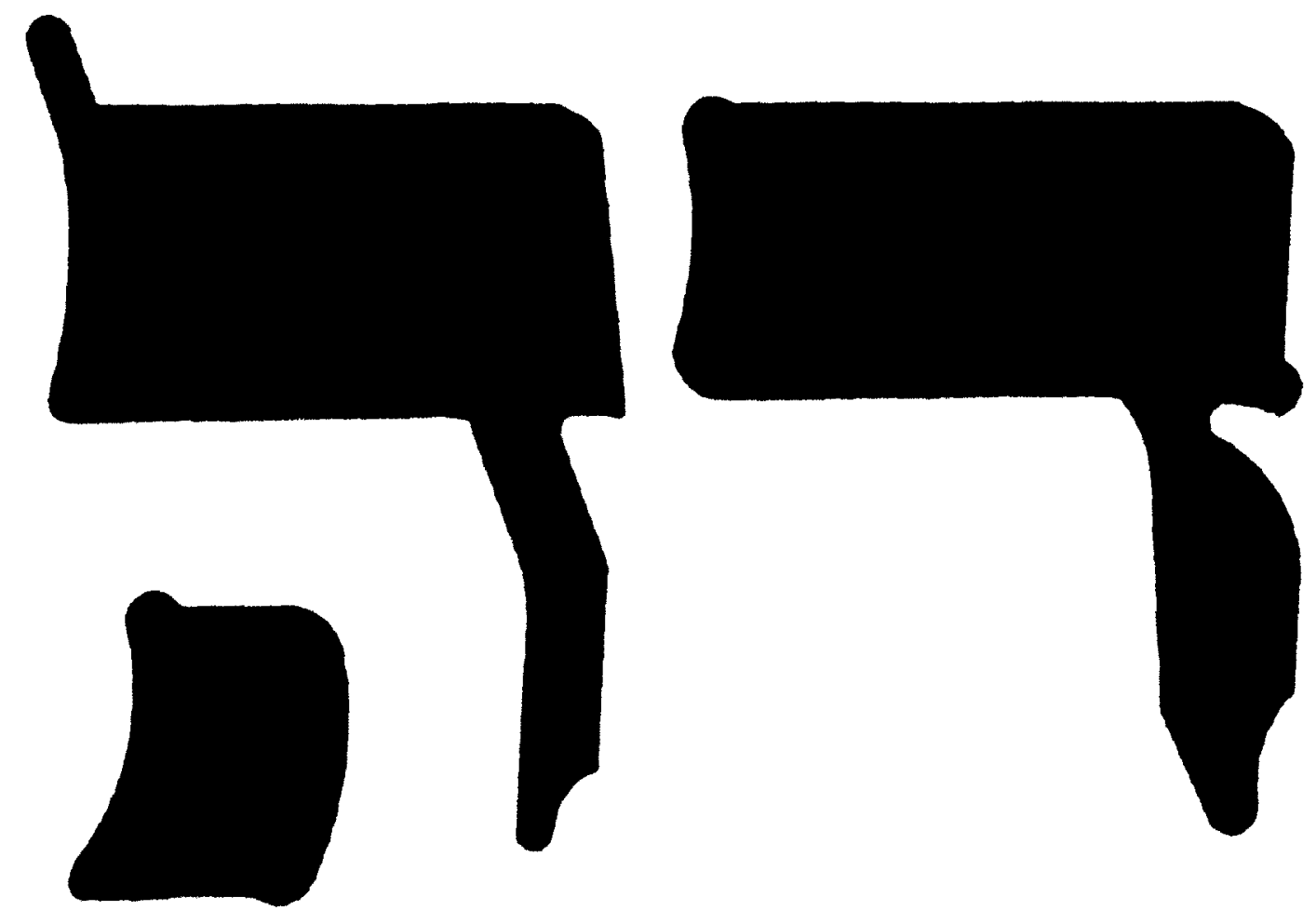

Figure -60/ Hebrew extruded letter panel. IIlustration by the author. 


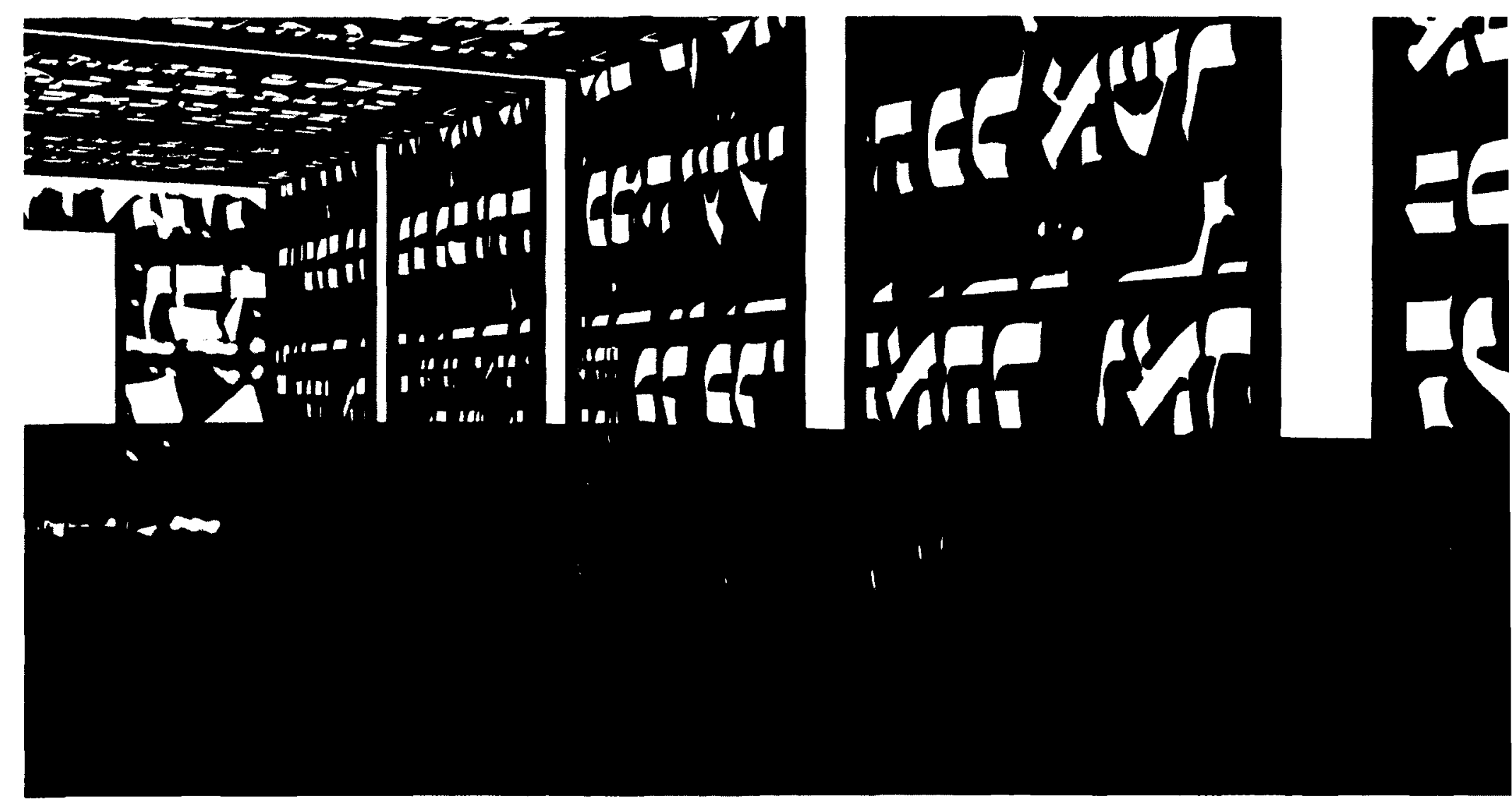

Figure - 61 IInterior view, Curtain Wall Shading Device. IIlustration by the author. 



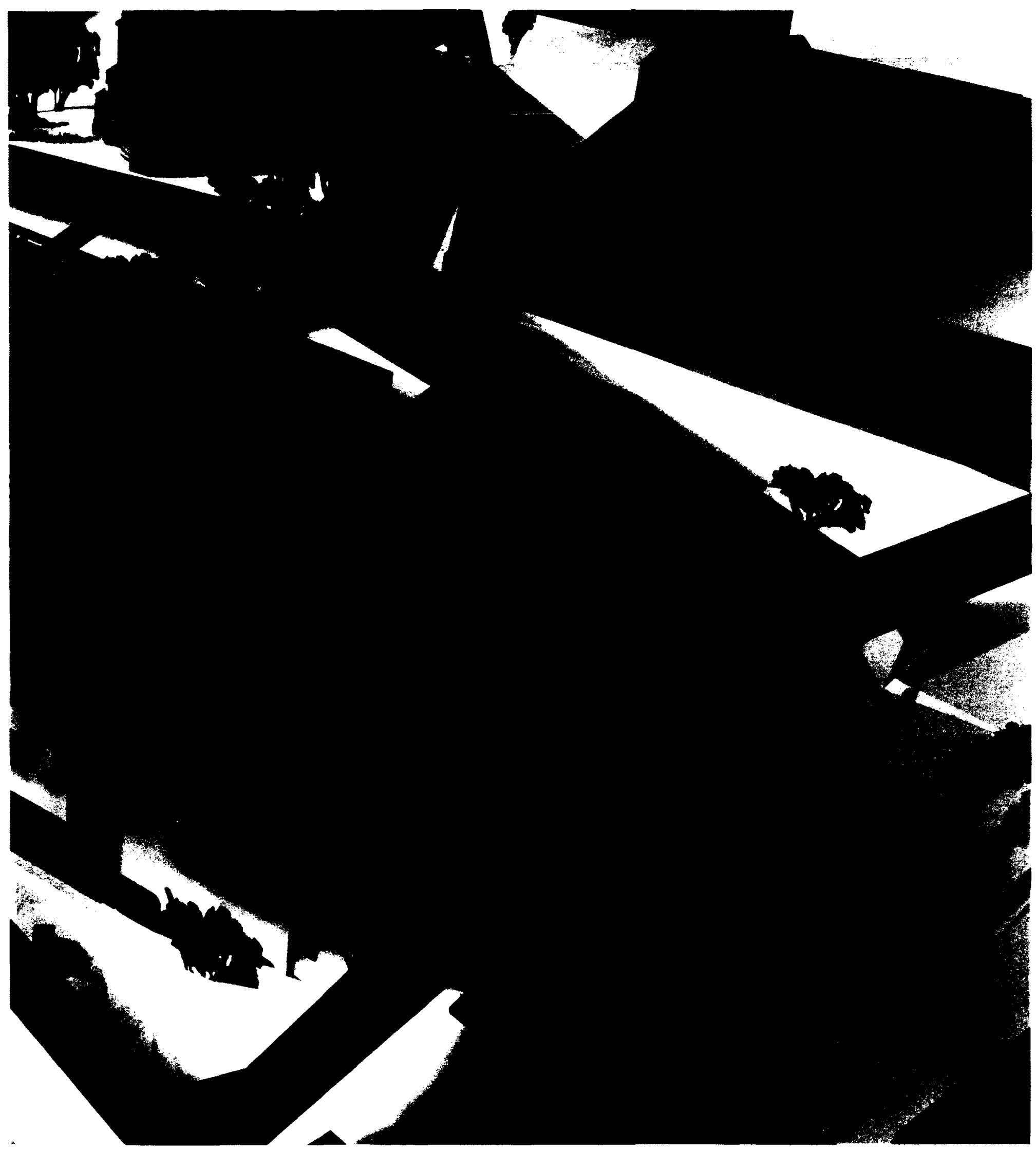

Figure - 62 |Exterior Perspective. Illustration by the author. 



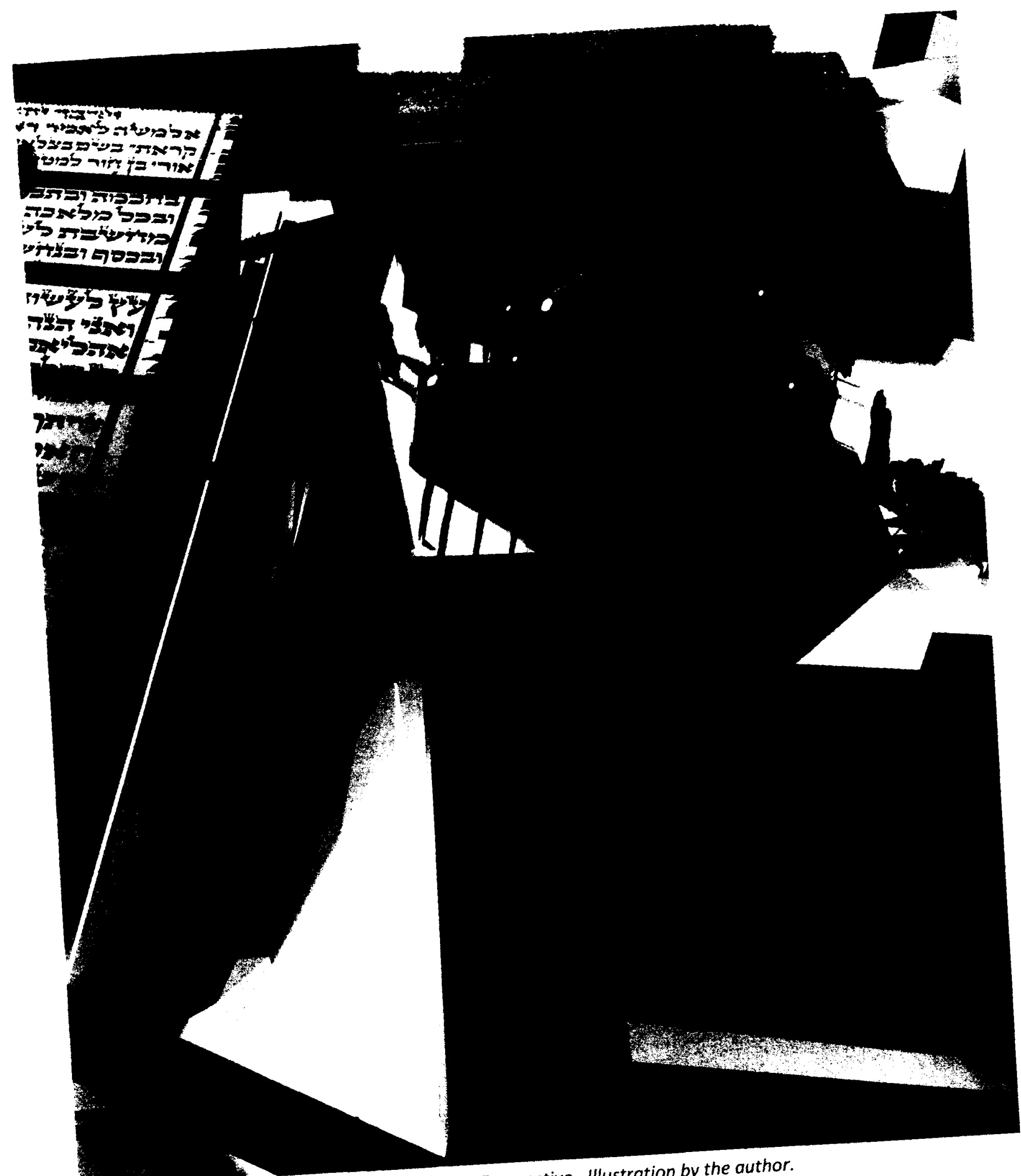

Figure - 63 | Exterior Perspective. IIlustration by the author. 
This proposal for the new campus of the Bezalel Academy of Art and Design, is suggestive of some of the possible architectural opportunities in considering the role of Jewish theological and cultural ideas in design. The subject of design rooted in Judaism, mildly explored in the contemporary architectural domain, has much potential. It is an opportunity to incorporate a prominent language of Judaism within the concepts and details of inhabited spaces, celebrating contemporary Jewishness in architecture. 


\section{Shabbes Cholent}

There are a series of issues that curb attitudes towards the thinking about, the designing, and ultimately the funding of a contemporary architecture with Judaism in mind. In some ways the reality, of how the architectural competition for the Bezalel Academy unfolded, speaks of this condition. This reality is a part of a modern day Jewish narrative, specifically in Israel, where struggles with an ideology of embracing a rich historical tradition while simultaneously attempting to shed outdated customs, is in constant flux.

By selecting an architectural proposal with little relationship to Jewish values, principals and ideals, subtly and not so subtly one inscribes in the minds of future designers that their professional principals and training are culturally borrowed from a Diaspora-tic existence. Building a Bezalel campus solely made from architectural ideas with little relationship to Judaism (religiously, culturally, nationally, or otherwise) furthers the belief that a Jewish architectural language doesn't exist. On the surface the Bezalel academy projects certain core principals, those of finding a visual and experiential expression towards a much yearned for national and spiritually independent Jewish design culture. If the Academy points to these principals as being of importance they should be celebrated by being at the heart of the design of their institution. 
The twentieth century architectural creation of the State of Israel began with an effort to layer the languages of both 'Eastern' and 'Western' methods of building. The first Zionists imagined Israel as being a bridge between 'Western' and 'Eastern' ideals, cultures, and technologies. In the late 19 th \& early 20 th centuries these ideas may have seemed appropriate for a community of first generation immigrants, the resulting architectural statement becomes one of borrowed techniques, 'blending in' with the surrounding architecture, and/or a kind of imperialist domination of oriental techniques. It is remarkable that Israel's first school of architecture and civil engineering (The Technion, built in 1912) [see figures: 64, 65] speaks of this language.

Yet the first generation of architects who trained in Israel, and the new European immigrants, schooled at the Bauhaus, weren't necessarily interested in subscribing to the initial British mandated Palestine design principles (of bridging a 'Western' and 'Eastern' design language). Additionally, as the Jewish state began taking shape under British control, Muslim Palestinians felt pressured by Jewish immigration; and began resisting the growth of the Palestinian Jewish community through various measures including acts of violence. These conditions, accompanying Zionist values of distancing the Jewish state from the European 'shtetl' 
traditions [see figure: 66], produced an optimal environment for embracing modern architecture of the 'International' movement (Bauhaus influenced) as the Israeli method of building. [see figure: 68]

"...young people who, sensing the approaching storm in Europe, came here and brought with them all the social, political, cultural and aesthetic innovations of their time. These young architects and builders had imbibed the tenets of Europe's incipient Modernism, which discovered the simple and the pure, rejecting conventional aestheticism, ornamental decorativeness and traditional materials. They employed basic forms and materials: the cube, the sphere, the cone, and the triangle; sand, gravel, water, cement, and concrete. ${ }^{n+3}$

Israeli 'modern' architecture (the architecture created from early 20th century until present day) is heavily influenced by these ideals and language. This is remarkable, not only as a world heritage site (" The White City of Tel Aviv can be seen as an outstanding example in a large scale of the innovative town-planning ideas of the first part of the 20th century. ${ }^{.44}$ ) but also in noting that in Germany, where these architectural ideas originated, both the Bauhaus and the Jewish community were destroyed.

\footnotetext{
${ }^{43}$ Metzger-Szmuk, Nitza \& Dani Karavan Dwelling On The Dunes Tel Aviv Modern Movement and Bauhaus Ideals Tel Aviv, IL: Kal Press Itd, 2004, p.13

${ }^{44}$ Metzger, Nitza Nomination of The White City of Tel Aviv Paris, France: United Nations Education, Scientific and Cultural Organization Internet: http://whc.unesco.org/uploads/nominations/1096.pdf, [02.12.2011] p.60
} 
So, what is not to embrace about the Jewish State building it's architectural landscape using modernist principals, those that originated from the Bauhaus? The very real situation in Israel highlighted the International movement's initial goals of modernism by having limited resources and in using minimal detailing in order to cut costs and labour. In other parts of the world this modern language of building was limited to wealthy clientele having the financial security to experiment with an Architect in building something contemporary. In my opinion it is true that the International Architecture in Israel is beautiful, remarkable, and impressive that it was even realized, however is it not a borrowed architectural language? An architecture from the Diaspora, realized in the Middle East by Jewish Zionist Architects uninterested in reliving horrible experiences from their past by addressing their own cultural tradition in their architecture?

Having a country where Judaism is the prevailing culture is a unique opportunity in exploring Jewish relationships to contemporary architecture. This opportunity would first require a shedding of the Jewish architectural mindset of an identity set in cultural acceptance from the 'host nation'. 


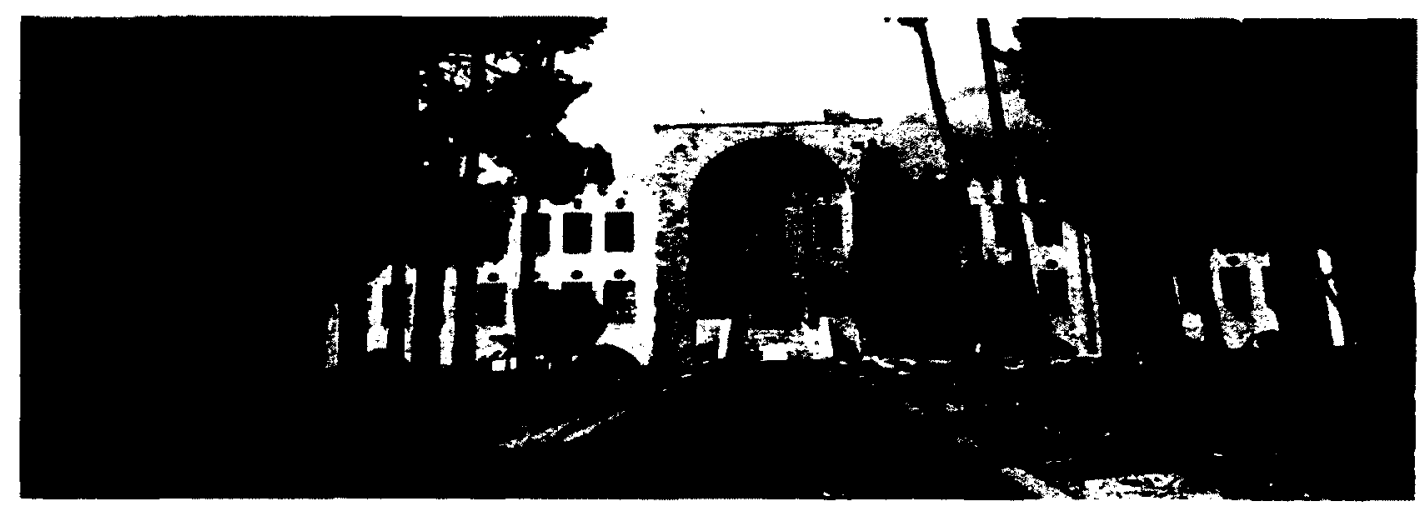

Figure - 64 / Origninal Technion Building. Source:

http://www.israelpictures.org/?p=105

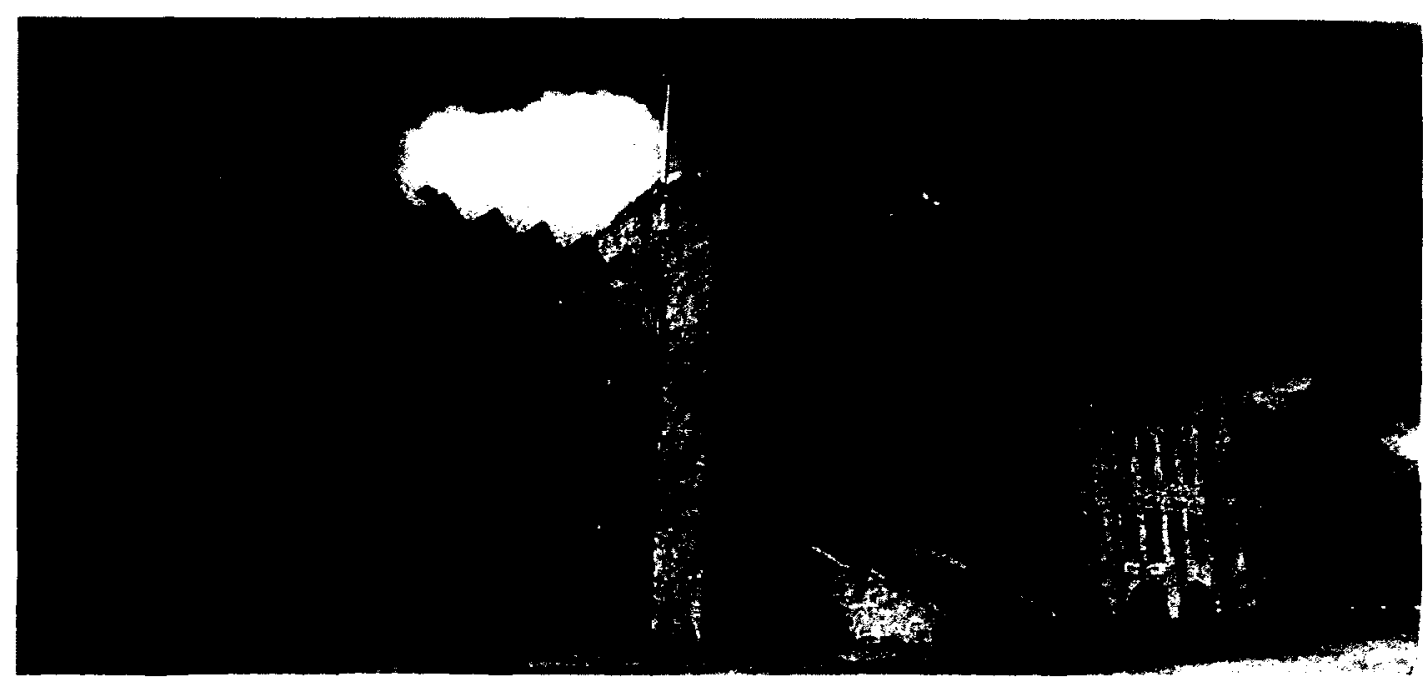

Figure - 65 /Original Technion Building. Source: http://www.israelpictures.org/?p=105 


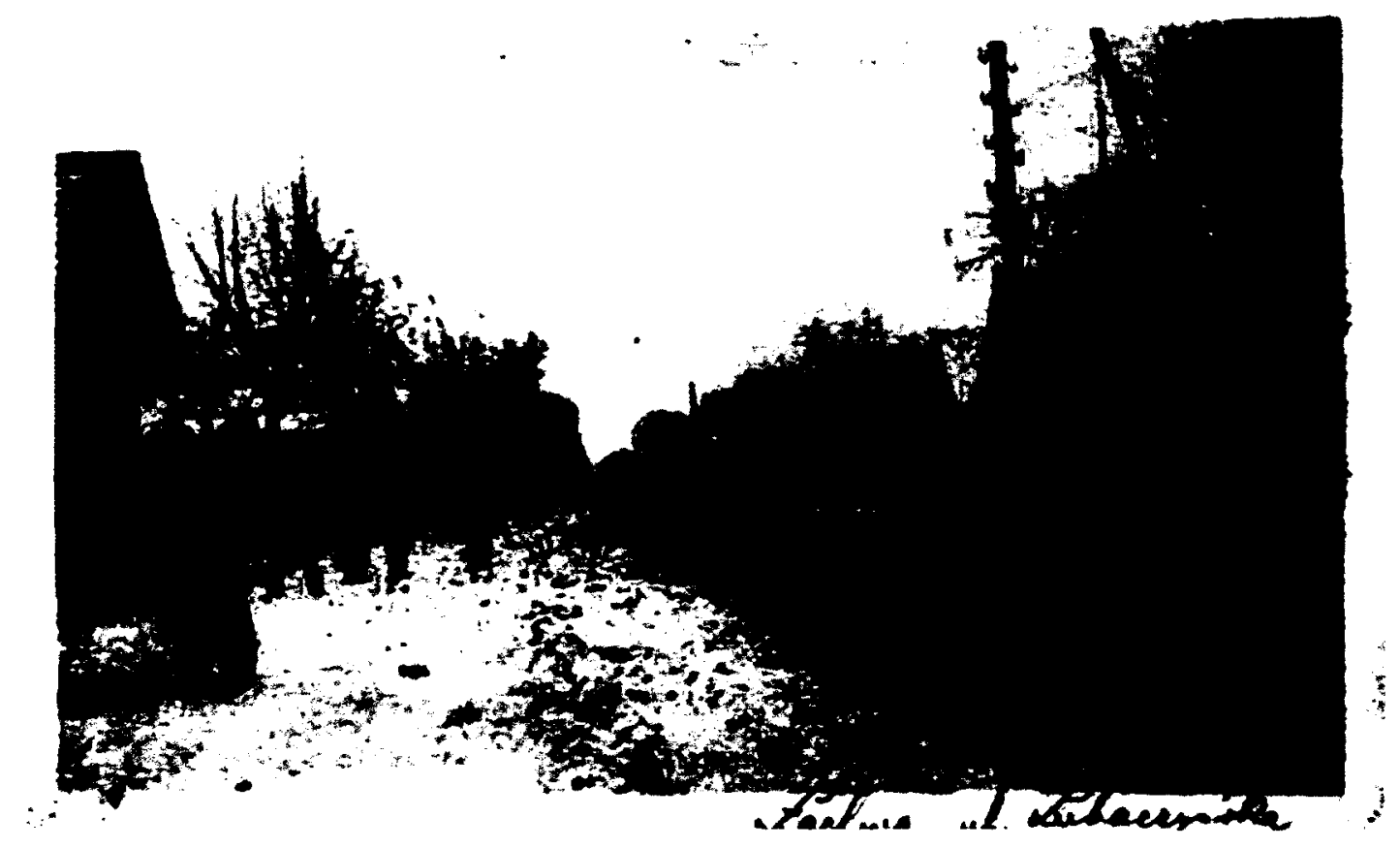

Figure - 66 /Shtet/ - Lakhva, Poland 1926 . Source:

http://en.wikipedia.org/wiki/File:Lakhva1926.jpg 


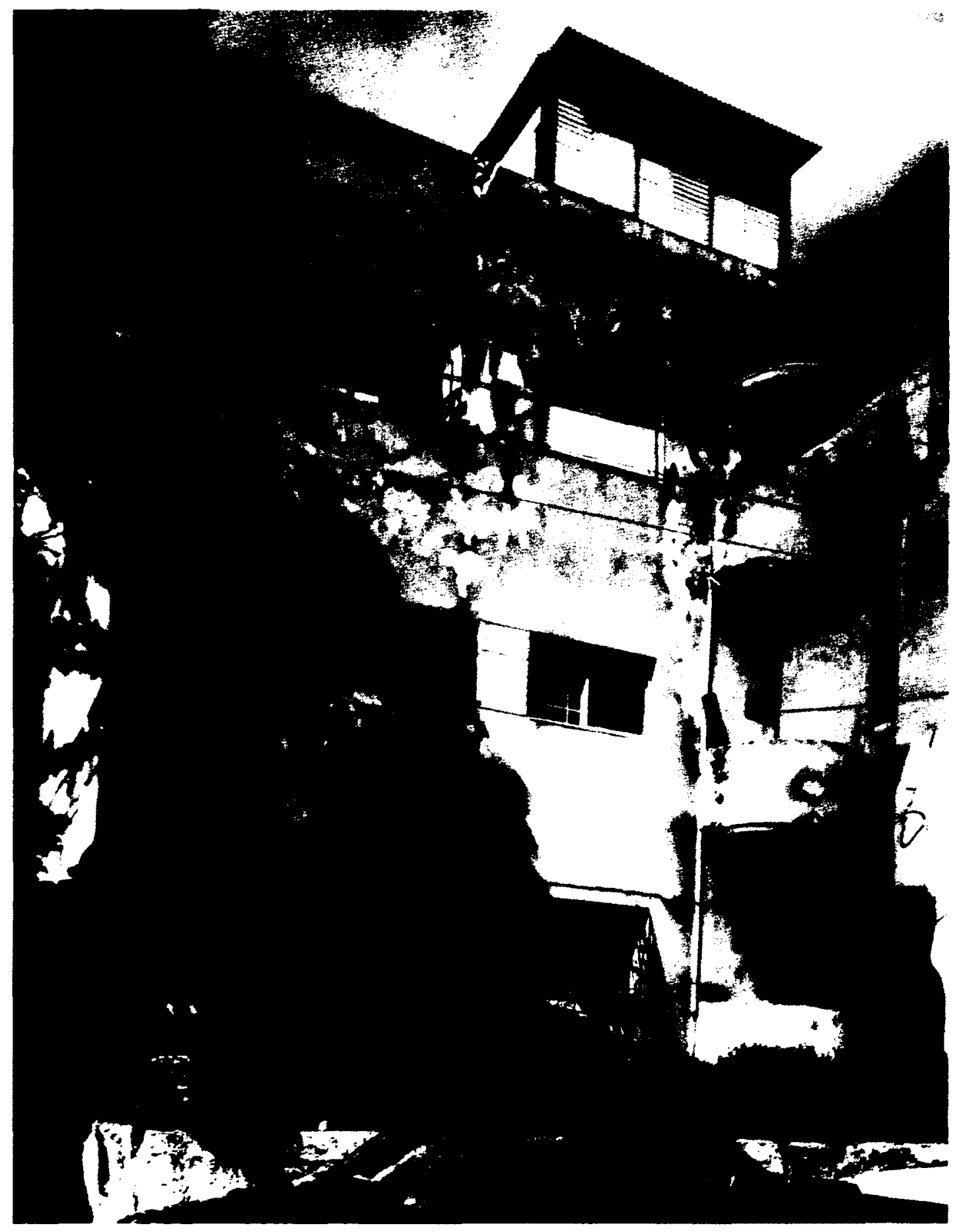

Figure - 67 / Archetypal Building in Tel Aviv's "White City". Source: MetzgerSzmuk, Nitza \& Dani Karavan Dwelling On The Dunes Tel Aviv Modern Movement and Bauhaus Ideals Tel Aviv, IL: Kal Press Ltd, 2004. 


\section{Bibliography}

Aish HaTorah's Discovery Seminar. The great success of Jewish tradition is the meticulous transmission of the Torah text. But actually how accurate is it? Internet Article:

http://www.aish.com/h/sh/tat/48969731.html, May 14, 2002 [July 27, 2012]

BBC Zorn: A Radio Documentary CD2 London, UK: BBC Radio 2000

Ben-Yehuda, Ehud and David Weinstein Ben-Yehuda's Pocket EnglishHebrew Hebrew-English Dictionary New York, NY: Pocket Books, a division of Simon \& Schuster Inc. 1961

Berg, Rav P.S. The Energy of Hebrew Letters: The Quantum Story of the Original Alphabet New York, NY: Kabbalah Centre International, Inc. 2010

Bezalel Academy of Arts and Design Website Section-About Bezalel>Landmarks Internet:

http://www.bezalel.ac.il/en/about/landmarks/, [ June16th 2012]

Chyutin, Bracha and Michael Chyutin. בצלאל בגנות, האדריכלית התחרות בזכות For the Architectural Competition, Against Bezalel. Hebrew Article from Xnet (translation by the author) Internet: http://www.xnet.co.il/architecture/articles/0,14710,L-3088290,00.html, September 13th 2011 [ April 18th 2012]

Dvir, Noam Bezalel Academy Picks award-winning Japanese firm to design campus HaAretz Online, Internet:

http://www.haaretz.com/print-edition/news/bezalel-academy-picks-award-w inning-japanese-firm-todesign- new-campus-1.383136, Sept. 08, 2011 [ June 18th 2012] 
Dvir, Noam 'Starchitecture' vs. homegrown design HaAretz Online, Internet:

http://www.haaretz.com/weekend/week-s-end/starchitecture-vs-homegrow n-design-1.387183, Sept. 28, 2011[ June 18th 2012]

Ginsburgh, Rabbi Yitzchak. The Hebrew Letters Channels of Creative Consciousness Rechovot, Israel: Linda Pinsky Publications, 1992

Goldberg Marks, Cara. The Handbook of Hebrew Caligraphy Northvale, $\mathrm{NJ}$ : Jason Aronson Inc. 1995

Improv 21. Q+A: An Informance with John Zorn (2007) Internet: http://archive.org/details/IMP_2007_11_15, November 15, 2007 [May 26th 2012]

Jewish Publication Society (translator) The Holy Scriptures According to the Masoretic Text Philadelphia, PA: The Jewish Publication Society of America 1916

Kaplan, Aryeh. Bahir: Illumination. Kindle Edition. York Beach, ME: Samuel Weiser, Inc. 1989

Kaplan, Aryeh. Sefer Yetzirah The Book of Creation San Francisco, CA: Red Wheel/Weiser, LLC, 1997

Metzger, Nitza Nomination of The White City of Tel Aviv Paris, France: United Nations Education, Scientific and Cultural Organization Internet: http://whc.unesco.org/uploads/nominations/1096.pdf, [02.12.2011]

Metzger-Szmuk, Nitza \& Dani Karavan Dwelling On The Dunes Tel Aviv Modern Movement and Bauhaus Ideals Tel Aviv, IL: Kal Press Itd, 2004

Munk, Rabbi Michael L. The Wisdom In The Hebrew Alphabet - The Sacred Letters as a Guide to Jewish Deed and Thought Brooklyn, NY: Mesorah Publications LTD. 1983 
Neufert, Ernst \& Peter Neufert, Bousmaha Baiche \& Nicholas Walliman Neufert Architects' Data, Third Edition Oxford, UK: Blackwell Science Ltd., 2000

Portnoy, Marshall and Josee Wolff. The Art of Torah Cantillation New York, NY: Union of American Hebrew Congregations Press, 2000

Scherman, Rabbi Nosson. Schottenstein Edition of the Talmud Berachos volume 2 (folios 30b-64a). Brooklyn, NY: Mesorah Artscroll Publications, LTD. Berachos

Scherman, Rabbi Nosson. The Chumash (the artscroll series / Stone edition) - The Torah: Haftoros and five Megillos with a commentary anthologized from rabbinic writngs Edited by Rabbi Hersh Goldwurm, Rabbi Avie Gold, and Rabbi Meir Zlotowitz. Brooklyn, NY: Mesorah Publications Ltd, 1993

Scholem, Gershom On The Kabbalah and Its Symbolism New York, NY: Schocken Books 1965

Solomon, Norman. The Talmud A Selection London, UK: Penguin Classics, 2009

Uittenbogaard, Arie. The Hebrew Alphabet-On the meaning of the Hebrew Alphabet Internet: http://www.abarimpublications.com/Hebrew_Alphabet_Meaning.html\#.UBLNb7StLKd, [July 27, 2012]

Weill, Asher [Editor] King Solomon's Seal A selection from The Israel Review of Arts and Letters 1998/vol 106 Internet: http://www.mfa.gov.il/MFA/MFAArchive/1990_1999/1999/2/King_Solomon -s_Seal, Februay 16, 1999 [August 05,2012]

Wikipedia - The Free Encyclopedia Seal of Solomon Interntet: http://en.wikipedia.org/wiki/Seal_of_Solomon, July 16, 2012 [August 5, 2012] 


\section{List of Illustrations}

ALL IMAGES COPYRIGHT OF THE AUTHOR UNLESS OTHERWISE NOTED.

Figure - 1 / Fronticepiece ii

Figure - 2 | Bezalel - as in Exodus 31. Watercolour by James Tissot

Source: $h t t p: / / w w w . w c g . o r g / i m a g e s / b 2 / b 2 v \% 20(20) . j p g$

Figure - 3 / Logo for the Bezalel Academy of Art and Design.

Source: http://upload.wikimedia.org/wikipedia/en/a/a2/Bezalel11.jpg $v$

Figure - 4 / John Zorn,

Source: http://indiemusic.co/files/2011/12/John-zorn_wide.jpg vi

Figure - 5 / Gematria Chart. Source:

http://www.inner.org/gematria/gemchart.htm 18

Figure - 6 / Gematria equation for Child. Image by the author

Figure - 7 / Ceramic work by Zeev Holtzman. Source:

http://www.imj.org.il/images/exhibitions/2006/schatz/Slide13.jpg 26

Figure - 8 / Portrait Illustration by E.M. Lilien. Source:

http://www.gwu.edu/ gelman/spec/kiev/expressions/lilien.htm

Figure - 9 / Illustration by Hermann Struck. Source:

http://safed-tzfat.blogspot.co.il/2008/04/el-rostro-de-la-judera-de-la-europa.html ... 27

Figure - 10 / Photography by Brit Shalit. Source:

http://www.bezalel.ac.il/en/galleries/artwork/?exhibition=1117\&referer $=54 \&$ refereru=

$\% 2$ fen\%2fgalleries\%2f54.htm/\&id $=8815$

Figure - 11 / Design by Avi Fadida. Source:

http://www.bezalel.ac.il/en/galleries/artwork/?exhibition=1117\&referer $=54 \&$ refereru= $\% 2$ fen\%2fgalleries\%2f54.htm/\&id $=8842$

Figure - 12 / Photography by Gidon Levin. Source:

http://www.bezalel.ac.il/en/galleries/artwork/?exhibition=1117\&referer $=54 \&$ refereru=

$\% 2$ fen\%2fgalleries\%2f54.html\&id=8819

Figure - 13 /Sketchup method word 'Makom' (space)

Figure - 14 / Tracing the K'Tav Yosef script in 3D Space 43

Figure - 15 / Lofting the curves of the name Bezalel, using site plan schematic 44 
Figure - 16 / Lofting the curves of the name Bezalel, using site plan schematic

Figure - 17 / Lofting the curves of the name Bezalel with unequal number of verteces

Figure - 18 /Lofting curves with equal number of verteces

Figure - 19 / Lofting curves with equal number of verteces

Figure - 20 /Diagrams expressing Hebrew letter Kabalistic relationships. Source: Kaplan, Aryeh. Sefer Yetzirah The Book of Creation San Francisco, CA: Red Wheel/Weiser, LLC, 1997

Figure - 21 /Hebrew letter Diagram expressing the 231 Gates. Source:

Kaplan, Aryeh. Sefer Yetzirah The Book of Creation

San Francisco, CA: Red Wheel/Weiser, LLC, 1997

Figure - 22 (Hebrew Words with n'ginot (cantillation notation). Text Image modified by author. Source: Scharstein, Asher Ben David. Tikun La-Kor'im: Kolel Hamsah Humshe Torah Hoboken, NJ: Ktav Publishing House Inc. 1969

Figure - 23 /IIlustrated n'ginot (cantillation notation) 56

Figure - 24 ILocal Jerusalem Stone Quarry. Image by the Author 64

Figure - 25 lOld City Jerusalem street - scape.

Source: $h t t p: / / w w w$.flickr.com/photos/alexsven/7472623126/in/pool-jerusalem 65

Figure - 26 /Old City Jerusalem Zion Gate.

Source: http://www.flickr.com/photos/alexsven/7472617372/in/pool-jerusalem 66

Figure - 27 /Old City Jerusalem Armenian Quarter Window detail.

Source: $h$ ttp://www.flickr.com/photos/thelastdon/7622242392/in/pool-jerusalem 67

Figure - 28 /Calculating polygonal traverses using basic geometrical shapes.

Source: Neufert, Ernst \& Peter Neufert, Bousmaha Baiche \& Nicholas Walliman Neufert Architects'Data, Third Edition Oxford, UK: Blackwell Science Ltd., 2000. 68

Figure - 29 | Polygon traverses used in creating round linear design.

Source: Neufert, Ernst \& Peter Neufert, Bousmaha Baiche \& Nicholas Walliman Neufert Architects' Data, Third Edition Oxford, UK: Blackwell Science Ltd., 2000 69 
Figure - $\mathbf{3 0}$ /Graphic Standards Arch examples.

Source: Ramsey, Charles George \& Harold Reeve Sleeper \& John Ray Hoke Jr. Architectural Graphic Standards CD-ROM V3.0 New York, NY:

John Wiley \& Sons Inc., 2000

Figure - 31 / The Seal of Solomon at Lions Gate, Old City Jerusalem.

Source: http://star-of-david.blogspot.co.il/2010 0831 archive.html

Figure - 32 / סגולות (sigils) - Angelic script including the Seal of Solomon.

Source: Savedow, Steve. Sepher Rezial Hemelach: The Book of the Angel Rezial

Kindle Edition, York Beach, ME: Samuel Weiser Inc., 2010

Figure - 33 /Three Point Arch and Six Point Arch influenced by the Seal of Solomon. Illustration by the author

Figure - 34 IFirst Parshot revealing the Biblical Character of Bezalel, In K'Tav Beit Yosef (Torah script). Source: Scharstein, Asher Ben David. Tikun La-Kor'im: Kolel Hamsah Humshe Torah Hoboken, NJ: Ktav Publishing House Inc. 1969 78

Figure - 35 / Open concept axonometric floor plan with Fine Arts faculty in colour. Illustration by the author 86

Figure - 36 / Open concept axonometric floor plan faculty detail. Illustration by the author

Figure - 37 / Cross Section with two level Faculty unit (Open Concept \& Truss Floor)in colour. Illustration by the author 88

Figure - 38 / Truss layout axonometric floor plan with second floor of Fine Arts faculty in colour. Illustration by the author.... 89

Figure - 39 / Axonometric floor plan Fine Arts second floor faculty detail. Illustration by the author 90

Figure - $\mathbf{4 0}$ / Axonometric floor plan Common Spaces. IIlustration by the author 91

Figure - 41 / Lattice modifier structural definition exercise results. Illustration by the author 94

Figure - 42 I Sub Division modifier structural definition (pre polygon face deletion) exercise results. Illustration by the author 95

Figure - 43 | Sub Division modifier structural definition detail, exercise results. Illustration by the author

Figure - 44 / Sub Division modifier stray vertice detail, problematic areas. Illustration by the author 
Figure - 45 / Parametric Array, exercise results. Illustration by the author

Figure - 46 / LongSection. Illustration by the author

Figure - 47 / Short Section. Illustration by the author 100

Figure - 48 / 231 Gates diagram, with the geometry for the name אהליאב (Oholiab). Illustration by the author \& Image from: Kaplan, Aryeh. Sefer Yetzirah The Book of Creation San Francisco, CA: Red Wheel/Weiser, LLC, 1997 ....................................... 102

Figure - 49 | אהליאב (Oholiab) geometry extrusions. IIlustration by the author ........ 103

Figure - 50 / אהליאב (Oholiab) truss. Illustration by the author .............................. 103

Figure - 51 / CrossSection. Illustration by the author 104

Figure - 52 / visual representation of the N'Ginot describing Bezalel. Illustration by the author using imagery from Figure - 23 \& Text: Scharstein, Asher Ben David. Tikun LaKor'im: Kolel Hamsah Humshe Torah Hoboken, NJ: Ktav Publishing House Inc. 1969 106

Figure - 53 / Extruding and scaleing the N'Ginot of Bezalel. Illustration by the author 107

Figure - $\mathbf{5 4}$ / Section with Circulation path in colour. Illustration by the author 108

Figure - 55 / Section with Circulation path in colour. Illustration by the author 109

Figure - 56 | Axonometric plan with load bearing walls in colour. Illustration by the author.

Figure - 57 / Arch proportion representation. Illustration by the author 112

Figure - $\mathbf{5 8}$ / Hebrew letter tracing in sketchup. Illustration by the author 114

Figure - $\mathbf{5 9}$ / Hebrew letter tracing in sketchup. Illustration by the author 114

Figure - $\mathbf{6 0}$ / Hebrew extruded letter panel. Illustration by the author 115

Figure - 61 IInterior view, Curtain Wall Shading Device. Illustration by the author .... 116

Figure - 62 | Exterior Perspective. Illustration by the author 117

Figure - 63 /Exterior Perspective. IIlustration by the author 118

Figure - 64 / Origninal Technion Building. Source:

http://www.israelpictures.org/?p=105 
Figure - 65 /Original Technion Building. Source:

http://www.israelpictures.org/?p=105

Figure - 66 /Shtetl - Lakhva, Poland 1926. Source:

http://en.wikipedia.org/wiki/File:Lakhva1926.jpg

125

Figure - 67 I Archetypical Building in Tel Aviv's "White City". Source: Metzger- Szmuk, Nitza \& Dani Karavan Dwelling On The Dunes Tel Aviv Modern Movement and Bauhaus Ideals Tel Aviv, IL: Kal Press Ltd, 2004 126 


\section{Acknowledgements}

To all of my family especially my parents Michael \& Judy Aranoff and

my sister Lindsay Aranoff and

my grandmother Katherine Fitch

To classmates and studio partners and

To my friends especially

Miron Epshtein

Itay Blaistain

Thomas Nemeskeri

Sabina Nieto

Danica Lau

Stefan Schulson \& Xiao Ning

Mark \& Amber Baechler

John Blias \& Emina Lojo

Those that didn't roll their eyes and

Those that did

To all of my Rabbim and Jewish Educators especially

Rabbi Shaya Greiniman

Rabbi Arnold Fine

Chazzan David Aptowitzer

Rabbi Ely Braun

Rabbi Leibish Hundert

To all of my underpaid and overworked Hebrew Teachers

Tsila Tuvyana

Irit Ulpan Ein HaShofet

To my Professors at the Technion especially

Professor Shmaya Serfaty

Professor Gaby Schwartz

To my Professors at Carleton University especially Professor Roger Connah

and my thesis advisor Professor Stephen Fai

I am very fortunate to have had all of your support

Thank you. 